\begin{abstract}
UNIVERSIDADE DE SÃO PAULO - USP
Programa de Pós-Graduação em Ciência Ambiental - Procam
\end{abstract}

Rosilene APARECIDA Nunes dos SANTOS

GovernanÇa da Água E Aprendizagem Social no SubCOMitê DA BACIA Hidrográfica Cotia-GUARAPIRANGA - REgIÃo Metropolitana de São Paulo

São Paulo 
O desafio a ser superado pela confiança, cooperação e corresponsabilização.

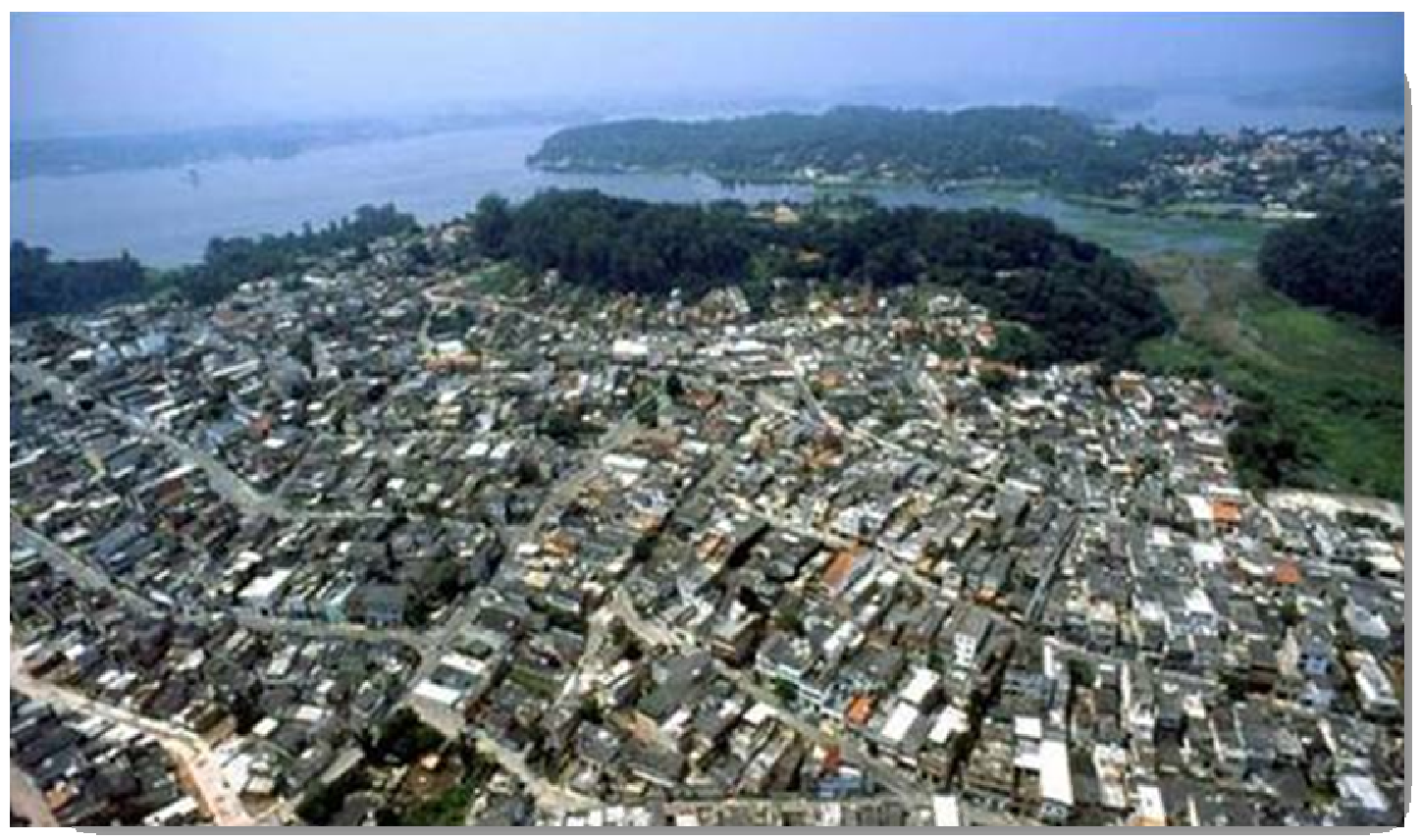

Ocupação urbana na represa Guarapiranga - Região Metropolitana de São Paulo FONTE: Whately e Cunha (2006a: 43).

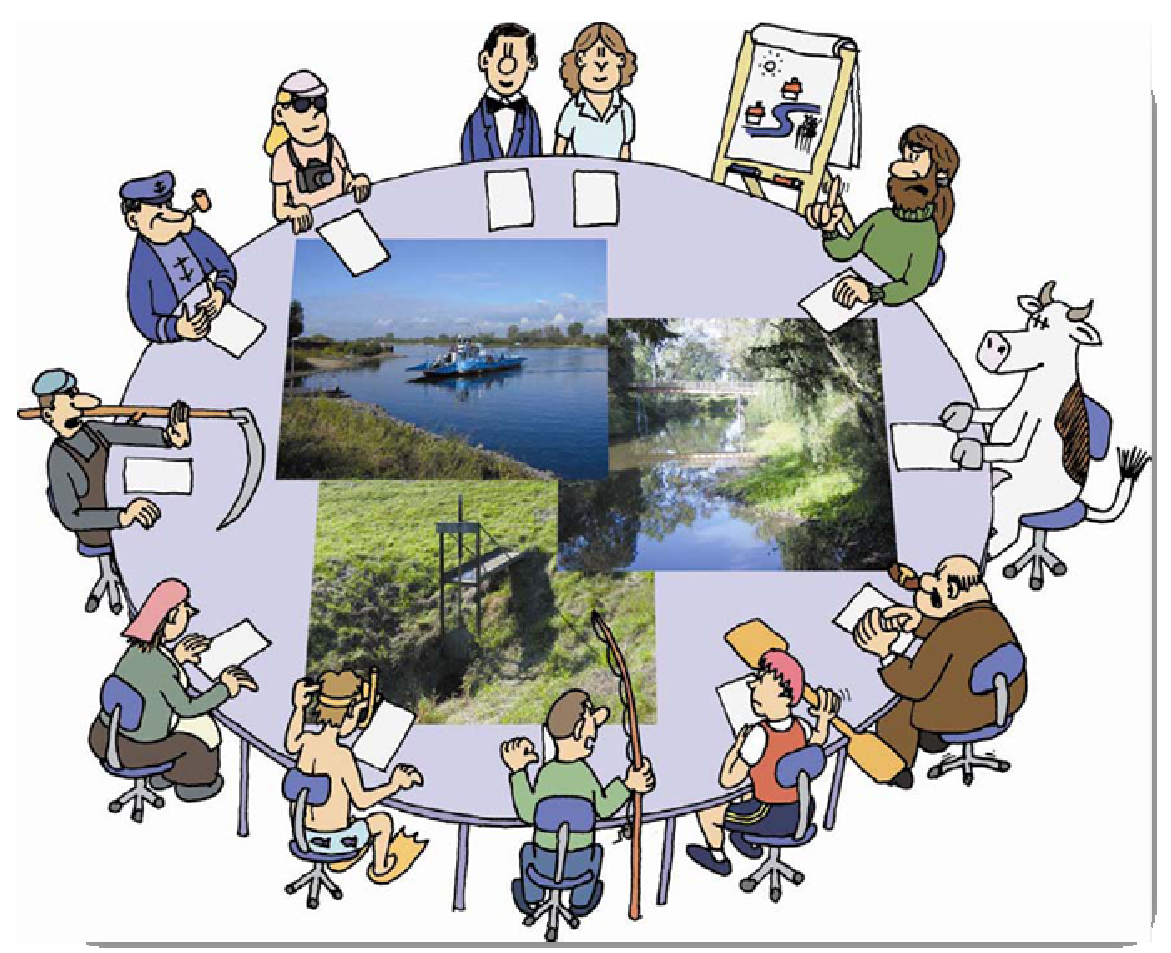

FONTE: Ridder, Mostert e Wolters (2005). 
Rosilene APARECIDA NUNES DOS SANTOS

\section{GovernanÇa da Água e Aprendizagem Social no SubComitê DA BACIA HidrográfiCA COTIA-GUARAPIRANGA - REgIÃo Metropolitana de São Paulo}

Dissertação apresentada ao Programa de PósGraduação em Ciência Ambiental da Universidade de São Paulo, para a obtenção do título de mestre em Ciência Ambiental.

ÁREA DE CONCENTRAÇÃO: Gestão compartilhada de recursos hídricos no Brasil: dimensões sociais e territoriais.

ORIENTADOR: Prof. Dr. Pedro Roberto Jacobi. 
AUTORIZO A REPRODUÇÃO E DIVULGAÇÃO TOTAL OU PARCIAL DESTE TRABALHO, POR QUALQUER MEIO CONVENCIONAL OU ELETRÔNICO, PARA FINS DE ESTUDO E PESQUISA, DESDE QUE CITADA A FONTE.

SANTOS, Rosilene Aparecida Nunes dos Santos.

Governança da água e aprendizagem social no subcomitê da bacia hidrográfica CotiaGuarapiranga - região metropolitana de São Paulo.

- São Paulo, 2009.

$120 \mathrm{p}$.

Dissertação de Mestrado, apresentada ao Programa de Pós-Graduação em Ciência Ambiental PROCAM/USP.

Orientador: Jacobi, Pedro Roberto.

1. Governança da água. 2. Gestão compartilhada de recursos hídricos. 3. Participação social. 4. Aprendizagem social. 


\section{FOLHA DE APROVAÇÃO}

\section{GOVERNANÇA DA ÁGUA E APRENDIZAGEM SOCIAL NO SUBCOMITÊ DA BACIA HIDROGRÁFICA Cotia-Guarapiranga - Região metropolitana de São PaUlo}

AUTORA: Rosilene APARECIDA NUNES DOS SANTOS

ORIENTADOR: PROF. DR. PEDRO ROBERTO JACOBI

Dissertação apresentada ao Programa de Pós-Graduação em Ciência Ambiental da Universidade de São Paulo, para a obtenção do título de mestre em Ciência Ambiental.

Área de Concentração: Gestão compartilhada de recursos hídricos no Brasil: dimensões sociais e territoriais.

\section{BANCA EXAMINADORA:}

1.

Prof. Dr. Pedro Roberto Jacobi

Instituições: Programa de Ciência Ambiental - PROCAM/USP

Faculdade de Educação - FE/USP

2.

Neli Aparecida de Mello

Instituições: Faculdade de Filosofia, Letras e Ciências Humanas - FFLCH/USP

Escola de Artes, Ciências e Humanidades - EACH/USP

3.

Ricardo Carneiro Novaes

Instituição: Faculdade de Educação - FE/USP

São Paulo, de de 2009. 
Aos meus amados pais,

Maria Helena Nunes dos Santos e Mozart Firmino dos Santos, pelo amor e confiança. 


\section{AgRAdeCimentos}

Agradeço primeiramente a Deus, pela minha vida e por todas as oportunidades proporcionadas, bem como, a beleza da natureza com a qual nos presenteia todos os dias.

À minha família, pelo amor, incentivo e compreensão durante as várias fases de realização deste trabalho acadêmico, sempre presente e com infindável carinho. Em especial aos sobrinhos(as) que alegram nossas vidas.

Ao meu orientador, Pedro Roberto Jacobi, pela atenção em toda orientação, incentivo e otimismo nos momentos de angústia e pelas oportunidades que me abriu. A convivência neste período enriqueceu minha vida e fez com que se tornasse um grande amigo, propiciando recursos para o meu desenvolvimento pessoal e profissional. O meu muito obrigada.

Aos professores do PROCAM, pela amizade, conselhos e sugestões para melhor aproveitamento do tempo de estudo, em especial Neli Melo e Monica Porto, pelas contribuições durante os comitês de orientação.

Ao Luciano e à Priscila, que sempre me atenderam com muita presteza.

Aos colegas do Grupo de Pesquisa Govagua, que conviveram comigo neste período, e que contribuíram para o amadurecimento, reflexão e elaboração deste trabalho.

A todos(as) os(as) entrevistados(as) do Subcomitê Cotia-Guarapiranga, pela atenção e disponibilidade no fornecimento das informações para a realização desta pesquisa.

Aos meus amados(as) amigos(as) de Brasília, onde foi semeado o percurso inicial deste mestrado, meus eternos inspiradores. Obrigada por me ensinarem tantas coisas, compartilharem dos meus sonhos e me ajudar a realizá-los.

Aos colegas de mestrado e doutorado, pelo companheirismo.

E agradeço de forma especial ao Programa Internacional de Bolsas da Fundação Ford e a todos(as) da equipe Fundação Carlos Chagas, que coordenaram os trabalhos para a efetivação da concessão da bolsa, sem a qual, não seria possível a realização desta pesquisa. 
A Terra provê o suficiente para a necessidade de todos, mas não para a voracidade de todos.

Mahatma Ghandi 


\section{RESUMO}

SANTOS, Rosilene Aparecida Nunes dos Santos. Governança da água e aprendizagem social no subcomitê da bacia hidrográfica Cotia-Guarapiranga - região metropolitana de São Paulo. 2009. 120p. Dissertação (Mestrado) - Programa de Pós-Graduação em Ciência Ambiental, Universidade de São Paulo, São Paulo, 2009.

Esta pesquisa analisou o processo participativo para a criação da Lei Específica da Guarapiranga (Lei n. ${ }^{\circ} 12.233$ de 16/01/2006), nos aspectos da governança da água e da aprendizagem social. A análise foi realizada com base na experiência do Subcomitê da Bacia Hidrográfica Cotia-Guarapiranga (SCBH-CG), na Região Metropolitana de São Paulo (RMSP). No processo de negociação para aprovação da referida Lei, estiveram envolvidos os representantes dos segmentos do Poder Público, Estado e prefeituras dos municípios da bacia, e da sociedade civil, no período de 1999 a 2006. Essa vivência demonstrou o quão desafiador é um processo de negociação entre os diferentes atores e diversos interesses no uso da água, que afetam a disponibilidade qualitativa e quantitativa na bacia da Guarapiranga, a qual abastece, aproximadamente, 4 milhões de pessoas na RMSP. Os resultados obtidos mostram que, embora esse processo tenha sido marcado por diversos momentos de tensão, conflitos, indefinições institucionais e morosidade, representou um significativo avanço na consolidação do sistema integrado de recursos hídricos. Cabe observar também que, apesar dos resultados poderem ainda parecer bastante modestos, face aos desafios existentes, estes representam um importante progresso em termos dos seus alcances para o fortalecimento de uma gestão democrática e compartilhada. Nesse contexto, pode-se concluir que a democracia participativa na governança das águas é um processo de aprendizagem social que vem sendo aperfeiçoado gradativamente para a sustentabilidade hídrica.

Palavras-Chave: Governança da água. Gestão compartilhada de recursos hídricos. Participação social. Aprendizagem social. 


\begin{abstract}
SANTOS, Rosilene Aparecida Nunes dos Santos. Water governance and social learning in the watershed subcommittee Cotia-Guarapiranga - metropolitan region of São Paulo. 2009. 120p. Dissertation (Master's) - Programa de Pós-Graduação em Ciência Ambiental, Universidade de São Paulo, São Paulo, 2009.

This research analyzes the participatory process that preceded the creation of the Specific Law for the Guarapiranga Basin (Law no. 12.233 of 16/01/2006), emphasizing aspects of water governance and social learning. The analysis was based on the experience of the watershed subcommittee Cotia-Guarapiranga (SCBH-CG) in the Metropolitan Region of São Paulo (MRSP). In the negotiation process for the approval of this law, representatives of the segments of the Government, state and local governments of municipalities of the basin, and civil society were involved from 1999 to 2006. This experience demonstrated the challenges of a process of negotiation among different stakeholders and their interests in water use that affect the availability of water in the Guarapiranga basin, which supplies about 4 million people in the MRSP. The results show that, although the process has been characterized by many moments of tension, conflicts, uncertainties and institutional delays, it represented a significant advance in the consolidation of the integrated system of water resources management in the basin. It should be noted also that although outcomes may seem modest, considering the existing challenges, they represent an important progress in terms of its scope to strengthen democratic and shared management of water resources. In this context, the conclusion is that participatory democracy in water governance is a process of social learning that has been improved gradually to reach more sustainability.
\end{abstract}

KEY WORDS: Water governance. Shared management of water resources. Social participation. Social learning. 


\section{LISTA DE FIGURAS}

Figura 1 - Mapa dos comitês de bacias hidrográficas do Estado de São Paulo.......... 38

Figura 2 - Mapa dos municípios da região metropolitana de São Paulo.......................... $\quad 60$

FIGURA 3 - Mapa da bacia Guarapiranga: uso do solo 2003 ……........................................ 66

FigurA 4 - Mapa da sub-bacia hidrográfica Cotia-Guarapiranga.......................................... 67

FigURA 5 - $\quad$ Mapa da bacia Guarapiranga - expansão urbana (1989-2003)...................... 69

FIGURA 6 - Ocupação urbana em parte da represa Guarapiranga (nov./2009).............. 72

FigURA 7 - Ocupação urbana em parte da represa Guarapiranga $\quad$.......................................... 73

FIGURA 8 - $\quad$ Mapa das áreas de intervenção na Guarapiranga................................................... 84 


\section{LISTA DE QUADROS}

QUADRo 1 - Composição da mesa diretora do subcomitê Cotia-Guarapiranga (1999 a 2007).

QUADRO 2 - Legislação ambiental básica aplicável à bacia hidrográfica da Guarapiranga..

QUADRO 3 - Instrumentos da Lei Estadual n. ${ }^{\circ}$ 9.866/97.

QUADRO 4 - Cronologia dos instrumentos legais relativos à Lei Específica da APRM-G. 


\section{LISTA DE SigLAS}

ACISE Associação Comercial, Industrial e de Serviços de Embu

ALESP Assembleia Legislativa do Estado de São Paulo

ANA Agência Nacional de Águas

AOD Área de Ocupação Dirigida

APP Área de Preservação Permanente

APRM Área de Preservação e Recuperação Ambiental

ARA Área de Recuperação Ambiental

ARO Área de Restrição à Ocupação

$\mathrm{CBH} \quad$ Comitê de Bacia Hidrográfica

CBH-AT Comitê da Bacia Hidrográfica do Alto Tietê

CERH Conselho Estadual de Recursos Hídricos

CONSEMA Conselho Estadual de Meio Ambiente

CPTG Câmara Técnica de Planejamento e Gestão

CT Câmara Técnica

GWP Global Water Partnership

ISA Instituto Socioambiental

ONU Organização das Nações Unidas

PDPA Plano de Desenvolvimento e Proteção Ambiental

PNRH Política Nacional de Recursos Hídricos

PL Projeto de Lei

RMSP Região Metropolitana de São Paulo

SCBH-CG Subcomitê de Bacia Hidrográfica Cotia-Guarapiranga

SEMPLA Secretaria Municipal de Planejamento

SINGREH Sistema Nacional de Gerenciamento de Recursos Hídricos

SRH/MMA Secretaria de Recursos Hídricos - Ministério do Meio Ambiente

UGRHI Unidade de Gerenciamento de Recursos Hídricos 


\section{SUMÁRIO}

1 INTRODUÇÃ

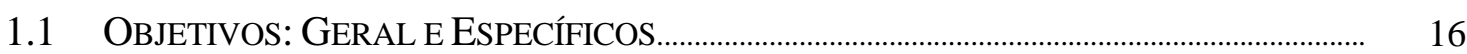

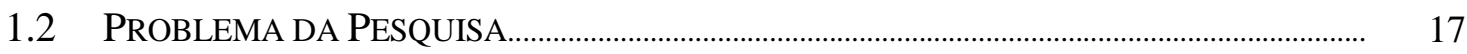

1.3 HIPÓTESE.

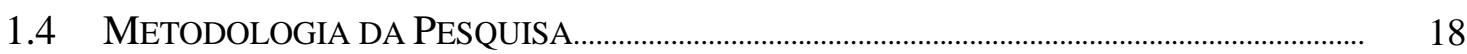

2 GOVERNANÇA E GOVERNABILIDADE NA GESTÃo COMPARTILHADA DE

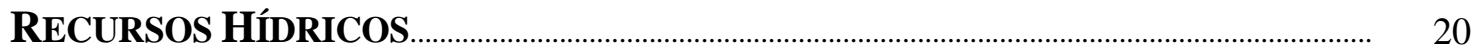

2.1 GovernanÇA DA ÁGUA: Dimensões ConCEITUAIS.................................................... 20

2.2 GOVERNANÇA E GOVERNABILIDADE DA ÁGUA................................................................. 25

2.3 FATORES PARA A BOA GOVERnANÇA DA ÁGUA................................................................... 27

2.4 A GeStÃo dos ReCURSOS Hídricos no BRASIL: Novo PARAdIGMA...................... 30

2.4.1 Política NACIONAL DE RECURSOS HídRICOS (LEI FEDERAL N. ${ }^{\circ}$ 9.433/97)... 33

2.4.2 Política EstaduAl DE RECURSOS HídRICOS DO ESTADO DE SÃo PAUlO (LEI N. ${ }^{\circ}$ 7.663/91) ………………………………………………………………………. 37

2.4.3 GESTÃo URBANA DAS ÁGUAS E SEUS DESAFIOS............................................................. 39

3 ParticipaÇão e Aprendizagem Social na Gestão Compartilhada

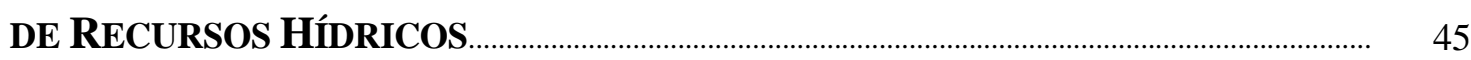

3.1 DIMENSÕES DA PARTICIPAÇÃO SOCIAL …………………………………………………........ 45

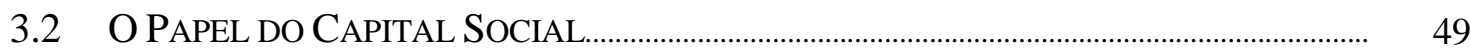

3.3 APRENDIZAGEM SOCIAL NA GESTÃO COMPARTILHADA DE RECURSOS HÍDRICOS...

4 Governança da ÁGua no Subcomitê de BaCia Hidrográfica COTIA-GUARAPIRANGA.

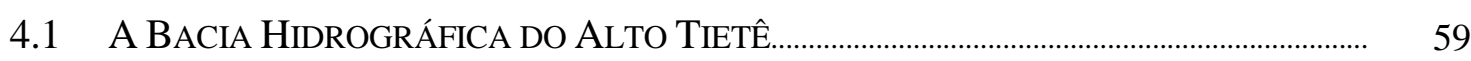

4.1.1 CARACTERÍSTICAS GERAIS............................................................................................ 59

4.1.2 A PROBLEMÁTICA DA BACIA.......................................................................................... 61

4.1.3 COMITÊ DA BACIA HIDRogRÁFICA Do ALTo TIETÊ................................................... 62

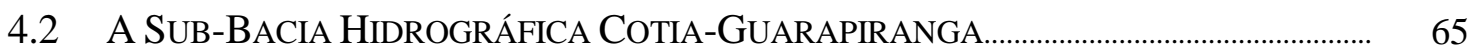

4.2.1 CARACTERÍSTICAS GERAIS................................................................................................ 65

4.2.2 A PROBLEMÁTICA DA BACIA ……………………………………………………………….... 70 
4.2.3 SUBCOMITÊ DA BACIA HIDROGRÁFICA COTIA-GUARAPIRANGA............................ 73

4.3 Lei de ProteÇÃo AOS ManANCIAIS (LEI N. ${ }^{\circ}$ 9.866/97).................................................. 78

4.4 LEI ESPECÍFICA DA GUARAPIRANGA (LEI N. ${ }^{\circ}$ 12.233/06): ORGANIZAÇÃO, ATORES ENVOLVIDOS E PROCESSO DE APRENDIZAGEM SOCIAL ......................................... 82

4.4.1 PROCESSO DE ELABORAÇÃO DA LEI ESPECÍFICA DA GUARAPIRANGA............... 85

4.4.2 ORGANIZAÇÃO E DINÂMICA DOS ATORES ENVOLVIDOS............................................ 90

4.4.3 PROBLEMAS, CONFLITOS E NEGOCIAÇÕES........................................................................... 90

4.4.4 RESULTADOS ALCANÇADOS...................................................................................... 94

5 CONSIDERAÇÕES FINAIS: A APRENDIZAGEM SOCIAL E SUA

CONTRIBUIÇÃo PARA A GOVERNANÇA DA ÁGUA ………………………………….... 98

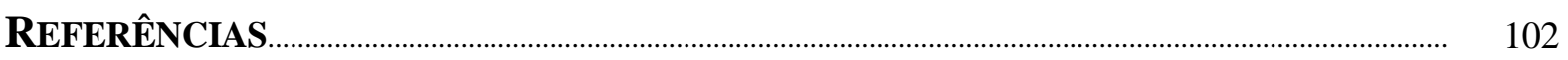

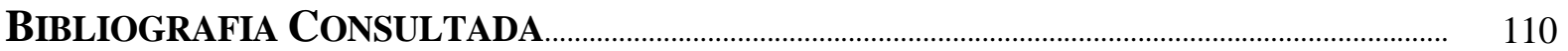

ANEXOS 


\section{INTRODUÇÃO}

Esta pesquisa tem por foco de análise o processo participativo para a criação da Lei Específica da Guarapiranga, nos aspectos da governança da água e da aprendizagem social. O arcabouço teórico utilizado encontra-se nos capítulos 2 e 3, apresentando a concepção do novo sistema de gestão das águas, que passa a ser descentralizada, integrada e participativa. Para essa compreensão, os referidos capítulos apresentam a concepção de governança e governabilidade da água no novo paradigma de gestão de recursos hídricos, bem como, as dimensões da participação social e o processo de aprendizagem social, a fim de consolidar a gestão compartilhada da água.

Esses capítulos apresentam a maneira pela qual o Brasil vem incorporando em seu arcabouço legal as concepções da governança da água, assim como a legislação do Estado de São Paulo que tem suas particularidades em relação à Política Nacional de Recursos Hídricos, no que se refere à composição dos Comitês de Bacia Hidrográfica (CBHs). A mudança na gestão da água se dá após diversas reflexões sobre a problemática hídrica, somada ao processo de redemocratização política.

A nova governança é desenhada e almejada com o objetivo de alcançar a sustentabilidade dos recursos hídricos nos diferentes níveis hierárquicos, local, nacional e internacional, pois para os recursos hídricos não há fronteiras, ou seja, para as águas não há divisão geopolítica; o que demanda dos setores público e privado, em conjunto com a participação da sociedade civil, uma gestão compartilhada. Nesse processo participativo ocorre uma aprendizagem social que propicia a governança da água.

No capítulo 4 é analisado o processo de elaboração e aprovação da Lei Específica que define a área de proteção e recuperação dos mananciais da bacia hidrográfica da Guarapiranga (Lei n. ${ }^{\circ} 12.233$ de 16 de janeiro de 2006). Nesse capítulo encontra-se também a apresentação da dinâmica dos atores envolvidos, os conflitos e as negociações, além dos resultados que foram alcançados por meio da participação social.

O capítulo 5 está focado na aprendizagem social e sua contribuição para a governança da água. É apresentada uma análise da experiência do SCBH-CG a respeito dos fatores para a governança e dos aspectos fundamentais da aprendizagem social. Esse conjunto demanda o 
máximo de horizontalidade no processo de tomada de decisão para ampliar a possibilidade de acordos e a participação dos diferentes atores da bacia, considerando a lógica da gestão compartilhada. Isso requer a busca pela compreensão da interdependência dos atores e da complexidade do sistema de gestão hídrica compartilhada.

No entanto, é preciso confiança, cooperação e corresponsabilidade na implementação dos acordos, sendo fundamental a possibilidade de aprender a trabalhar em conjunto, com participação de todos em diálogo constante, ou seja, juntos aprender para juntos intervir. Afinal, a aprendizagem social é um envolvimento que depende da lógica participativa e da consciência de que os objetivos e as perspectivas são diferentes entre os membros do grupo na arena de negociação.

\subsection{OBJETIVOS: GERAL E ESPECÍFICOS}

O presente trabalho tem por objetivo geral analisar o processo e os mecanismos participativos do Subcomitê da Bacia Hidrográfica Cotia-Guarapiranga (SCBH-CG), entre 1999 e 2006, com foco na aprendizagem social decorrente das negociações para a aprovação da Lei Específica de Proteção do Manancial Guarapiranga (Lei n. $\left.{ }^{\circ} 12.233 / 06\right)^{1}$.

Os objetivos específicos são:

1. Caracterizar os atores sociais e as instituições que representam, e o seu envolvimento no Subcomitê Cotia-Guarapiranga durante as quatro gestões que permearam a elaboração da Lei Específica;

2. Analisar o papel dos segmentos e as diferentes atividades que fomentaram a participação social para o aperfeiçoamento da prática da gestão participativa, descentralizada e integrada no Subcomitê Cotia-Guarapiranga;

3. Analisar a relação entre Poder Público e sociedade civil para a criação da Lei Específica de Proteção do Manancial Guarapiranga;

\footnotetext{
${ }^{1}$ São Paulo (2006).
} 
4. Apresentar contribuições que favoreçam a aprendizagem social e contribuam para a governança da água em regiões urbanas.

\subsection{Problema da Pesquisa}

O desafio da gestão compartilhada de recursos hídricos está presente não somente na Região Metropolitana de São Paulo (RMSP), como também em outras regiões do Brasil, da América Latina e do mundo. Buscar a corresponsabilização na governança da água é um processo de aprendizagem social que requer o envolvimento dos setores público, privado e sociedade civil, visando democratizar a gestão das águas.

Pensar a gestão por bacias hidrográficas, com ênfase nos comitês de bacias, requer pensar no fortalecimento da gestão participativa e compartilhada, com seus desafios e potencialidades. Para tanto, faz-se necessária a mobilização da sociedade para o envolvimento na proteção das águas.

As reflexões que são suscitadas por este trabalho de pesquisa enveredam no sentido de identificar quais fatores facilitam, colaboram ou restringem os mecanismos de aprendizagem social para o avanço da governança da água, com base no processo participativo de elaboração da Lei Específica da Guarapiranga, na Região Metropolitana de São Paulo.

A questão que se coloca é: quais fatores e mecanismos favoreceram o processo de aprendizagem social durante a elaboração e aprovação da Lei Específica de Proteção do Manancial Guarapiranga (Lei n. $\left.{ }^{\circ} 12.233 / 06\right)^{2}$ e qual é a sua replicabilidade por outros comitês de bacia para a concretude da governança da água?

\footnotetext{
${ }^{2}$ São Paulo (2006).
} 


\subsection{HiPÓTESE}

A hipótese colocada é que durante os oito anos de elaboração da Lei Específica da Guarapiranga ocorreu um processo de aprendizagem social com avanços e retrocessos; o que demonstra que lições foram apreendidas pelo Subcomitê Cotia-Guarapiranga e que estas poderão ser utilizadas em outros comitês de bacia, após análise de sua sistematização.

Em síntese, a aprendizagem social pode contribuir para a efetividade da governança da água com base em práticas já realizadas, que adotaram mecanismos participativos para a elaboração de políticas públicas voltadas para a gestão compartilhada de recursos hídricos.

\subsection{Metodologia da Pesquisa}

O processo de pesquisa consistiu na análise de documentação sobre o processo de elaboração da Lei Específica da Guarapiranga e de entrevistas com atores relevantes, tanto do Estado como dos municípios e da sociedade civil. Os atores entrevistados são membros do Subcomitê da Bacia Hidrográfica Cotia-Guarapiranga (SCBH-CG), com atuação na região da bacia antes mesmo da criação do SCBH-CG e depois como membros deste. Os entrevistados participaram de todo o processo de criação da Lei, e continuam atuando na região mobilizando a sociedade local a participar do processo de busca por melhorias socioambientais para a região.

O objetivo principal foi identificar, no histórico encontrado, como o processo participativo contribuiu para a governança da água e qual a aprendizagem social ocorrida no percurso de oito anos para aprovação da referida Lei, considerando as estratégias de negociação, facilitação e liderança, ferramentas de comunicação e informações utilizadas. Afinal, a experiência de elaboração da Lei foi um processo de construção coletiva para alternativas que respondam às demandas complexas da gestão compartilhada da água em regiões metropolitanas. 
As entrevistas realizadas foram semiestruturadas ${ }^{3}$, que são aquelas com as quais os atores sociais do SCBH-CG tiveram a possibilidade de discorrer sobre o tema proposto, através da aplicação de questões previamente definidas, o que possibilitou o aprofundamento nos assuntos de maior interesse (ver Anexo 1). Dessa forma, foi possível complementar as informações encontradas no registro documental, na medida em que as questões abertas propiciaram aos entrevistados abordar as temáticas livremente, sem que houvesse direcionamento ou indução de respostas.

Todo esse conjunto de práticas foi analisado à luz da revisão bibliográfica, principalmente para a compreensão de governança, participação, capital social e aprendizagem social presentes no processo de gestão compartilhada de recursos hídricos.

\footnotetext{
${ }^{3}$ Texto elaborado segundo as regras do Novo Acordo Ortográfico da Língua Portuguesa, vigente desde $1^{\circ}$ de janeiro de 2009.
} 


\section{GOVERNANÇA E GOVERNABILIDADE NA GESTÃo COMPARTILHADA DE RECURSOS HídRICOS}

\subsection{Governança da Água: Dimensões ConCeituais}

O mundo possui muitas fontes de água potável, apesar de serem mal distribuídas. Isso porque, um quinto da população do planeta não possui acesso a essa água e $40 \%$ não dispõem de condições sanitárias básicas (ONU, 2006). A habilidade para lidar com o contínuo crescimento da demanda global dependerá da boa governança dos recursos disponíveis; situação que é essencial para a gestão de recursos hídricos, pois gerir a água pressupõe responsabilidade compartilhada.

Segundo o relatório da ONU (2006), 1,1 bilhão de pessoas ainda não têm acesso a fornecimentos adequados de água potável. Em 2030, o mundo necessitará de 55\% a mais de comida, o que representa um aumento na demanda de água para irrigação, a qual já utiliza cerca de $70 \%$ de toda a água para consumo humano. Metade da humanidade se concentrará em cidades, aumentando a demanda por água nas áreas urbanas. Cerca de 2 bilhões dessas pessoas viverão em assentamentos irregulares e em favelas, localidades que nos dias atuais já sofrem com a falta de água potável e saneamento.

O relatório destaca que um sistema de governança determina qual, quando e como é distribuída a água e decide quem tem direito aos recursos e outros serviços adjacentes. Tal sistema não está limitado ao governo, pois inclui também autoridades locais, setor privado e sociedade civil. Da mesma forma, trata de uma série de questões ligadas à água, saúde e segurança alimentar para o desenvolvimento econômico, uso da terra e preservação dos ecossistemas naturais, dos quais nossas fontes de água dependem.

Diante dessa problemática hídrica mundial, eventos internacionais ao longo dos últimos trinta anos estão sendo realizados para debater a situação e buscar alternativas coletivas, com a participação do Poder Público, do setor privado e da sociedade civil, a fim de concretizar a gestão hídrica compartilhada. 
O percurso histórico desse processo ocorre juntamente com a revitalização da sociedade civil desde a década de 80 , quando ocorreu um esforço para a redemocratização política a fim de substituir o regime autoritário pelo regime democrático; o qual é representado pelos movimentos sociais organizados que pressionam pela democratização da gestão estatal, influenciando na elaboração de políticas públicas.

Esse período de transição foi marcado pela ruptura de velhos paradigmas, ascensão dos grupos sociais e ampliação da presença de organizações da sociedade civil na gestão pública. No Brasil, essas conquistas foram evidenciadas com a promulgação da Constituição Federal Brasileira de 1988, que expressa a conquista de espaço para a prática da democracia participativa (BRASIL, 2003).

No cenário internacional, a Declaração de Dublin, de 1992, evidencia que a escassez e o desperdício de água doce representam sérias e crescentes ameaças ao desenvolvimento sustentável e à proteção do meio ambiente, da saúde e do bem-estar do homem; pois a garantia de alimentos, o desenvolvimento industrial e o equilíbrio dos ecossistemas estarão sob risco se a gestão da água e do solo não se tornarem realidade na presente década, de forma bem mais efetiva do que ocorreu no passado (REDE DAS ÁGUAS, 2009). Nesse sentido, na Conferência Internacional sobre a água e meio ambiente, realizada em Dublin, foram estabelecidos os Princípios de Dublin que norteiam a gestão e as políticas para as águas em todo o mundo. Esses princípios refletem nos ordenamentos jurídicos e institucionais das políticas das águas de vários países; são eles:

Princípio 1: As águas doces são um recurso natural finito e vulnerável, essencial para a sustentação da vida, do desenvolvimento e do meio ambiente. A gestão das águas deve ser integrada e considerada o seu todo, quer seja a bacia hidrográfica e/ou os aquíferos.

Princípio 2: O desenvolvimento e a gestão da água devem ser baseados na participação de todos, quer sejam usuários, planejadores ou decisores políticos de todos os níveis.

Princípio 3: As mulheres têm um papel central na provisão e proteção da água.

Princípio 4: A água é um recurso natural dotado de valor econômico em todos os seus usos competitivos e deve ser reconhecida com um bem econômico (REDE DAS ÁGUAS, 2009).

Dessa forma, a partir dos anos 90, anseia-se por uma nova governança como símbolo da modernidade na gestão pública, a qual é considerada como um procedimento que inova a 
democracia, utilizando-se da gestão descentralizada com consultas democráticas e formas flexíveis de coordenação (THEYS, 2003). Diante desse contexto, ocorre uma mudança no processo de gestão pública, e a água passa a ter uma gestão participativa, descentralizada e integrada, sendo a bacia hidrográfica a unidade territorial de planejamento e de gestão.

A busca por uma melhor governança, fortalecendo vias para gerir os assuntos comuns num processo interativo, com corresponsabilidade, tem se tornado cada vez mais recorrente. Essa busca representa um avanço no sistema democrático da gestão do bem comum, pois perpassa os contextos sociais, econômicos e políticos de forma interdisciplinar (JACOBI, 2006).

Mas essa "nova" maneira de governar "não pressupõe substituir o governo, mas sim organizar sua articulação. Poder público, setor privado e sociedade civil fazendo a gestão coletiva dos problemas e construindo visões compartilhadas" (THEYS, 2003: 23-24).

Mas, o que é governança da água?

Ao apresentar a temática da governança da água é preciso mencionar que não há um conceito definido e tampouco um modelo único, mas sim compreensões que se encontram em processo de discussão para a evolução de um conceito. A seguir são apresentadas algumas concepções e, também, o entendimento que será considerado para este trabalho.

Para Rogers e Hall (2003), governança compreende um processo que precisa ter o Poder Público, o setor privado e a sociedade civil, juntos, buscando alternativas sustentáveis para a implementação das políticas públicas. Ou seja, é a construção de uma representação da realidade em um processo de ação coletiva, no qual a gestão da água ocorre de forma descentralizada, participativa e integrada (ROGERS; HALL, 2003).

Essa posição também é apresentada por Kooiman et al. (2008), que destacam que a governança não é apenas o Estado, mas também o setor privado e a sociedade civil. A partir desse raciocínio, Kooiman et al. (2008) apresentam a concepção de governança como sendo uma "governança interativa", devido ao conjunto de interações necessárias para se resolver os problemas sociais, criando assim oportunidades para a sociedade participar e interagir com os agentes públicos e privados. Mas para isso, faz-se necessária a formulação e aplicação de princípios que norteiem essas interações entre as instituições, com o intuito de possibilitar essa participação, pois, conforme enfatizam os autores, a interatividade é o caminho para a efetiva governança. 
Como apresentado anteriormente, devido à problemática hídrica mundial, diversos eventos internacionais têm sido realizados para buscar alternativas coletivas, e uma delas foi a criação do Global Water Partnership (GWP), em 1996, que é uma rede internacional aberta a todas as organizações envolvidas em gestão de recursos hídricos e que tem por finalidade promover a gestão integrada desses recursos.

Para o GWP (apud ROGERS; HALL, 2003), a governança da água refere-se ao leque de políticas sociais e econômicas, e ao sistema administrativo local para o desenvolvimento e gestão de recursos hídricos, bem como ao atendimento da demanda de água, servindo aos diferentes níveis da sociedade. Desse modo, para que ocorra a governança da água é preciso que haja a delimitação dos papéis e das responsabilidades dos diferentes stakeholders público, privado e sociedade civil - na gestão dos recursos hídricos e no desenvolvimento, buscando o equilíbrio de poder e de ações entre os diferentes níveis de autoridade. Nessa perspectiva, pode-se dizer que a governança se traduz em sistemas políticos, leis, regulamentos, instituições e em mecanismos financeiros e de desenvolvimento da sociedade, num contexto conjuntural integrado para a sustentabilidade ambiental.

De acordo com Brunnengraeber et al. (2006), o entendimento de governança é a soma das várias formas que indivíduos e instituições públicas e privadas realizam para gerenciar seus assuntos comuns. Trata-se de um processo contínuo através do qual os interesses conflitantes podem ser administrados de forma cooperativa, estabelecendo acordos que consideram o interesse comum. A esse acordo comum, Bustamante e Palacios (2005) denominam de "contrato social", no qual a governança é realizada por meio de arranjos institucionais e normas, com o objetivo de alcançar o equilíbrio e o estabelecimento de consensos entre os stakeholders. Nesse sentido, "governança se refere essencialmente a forma em que o poder e a autoridade são exercitados e distribuídos na sociedade, e como os cidadãos podem participar dos processos de tomada de decisões." (BUSTAMANTE; PALACIOS, 2005: 9-10, tradução nossa).

Uma visão instrumental para o processo de construção da governança da água é apresentado por Solanes e Jouravlev (2006). Segundo esses autores, deve-se entender por governança a capacidade que um sistema social tem de mobilizar energias de uma forma coerente e convergente para o desenvolvimento sustentável de recursos hídricos em um ambiente social complexo. Para isso, é preciso habilidade para se desenhar políticas públicas que sejam socialmente aceitas, com um viés de sustentabilidade, e capazes de efetivar suas implementações por diferentes atores envolvidos no processo. Portanto, a compreensão da 
governança da água perpassa pela noção de poder social que media as relações entre Estado e sociedade civil, permeada por conflitos decorrentes da participação dos diversos atores envolvidos.

No entanto, a governança da água no século XXI, conforme afirma Castro (2007), não pode ser reduzida a um instrumento de implementação de políticas públicas nem a uma estratégia idealizada entre seus atores. Governança é um processo político que envolve o exercício de poder realizado por atores políticos, ou seja, há o exercício da autoridade e do poder nesse processo de governança, caracterizado não somente pelo diálogo e negociação, mas também por conflitos políticos. $\mathrm{O}$ autor realiza diversas reflexões para chegar a uma posição quanto à compreensão da governança da água. Após análise, afirma que governança é a integração entre os atores interessados num contínuo debate sobre as questões da gestão de recursos hídricos de forma participativa e democrática; debate esse que se caracteriza pelo diálogo e pela negociação.

Para Jacobi (2009: 43),

[...] o termo governança representa um enfoque conceitual que propõe caminhos teóricos e práticos alternativos que façam uma real ligação entre as demandas sociais e sua interlocução em nível governamental. Geralmente, a utilização do conceito inclui leis, regulação e instituições, mas também se refere a políticas e ações de governo, a iniciativas locais, e a redes de influência, incluindo mercados internacionais, o setor privado e a sociedade civil, os quais são influenciados pelos sistemas políticos nos quais se inserem.

Assim sendo, percebe-se a importância de gestões democráticas para garantir a participação na governança, o que gera capital social por meio da aprendizagem social. Tal procedimento ocorre com o objetivo de melhorar o processo de negociação entre os diferentes stakeholders envolvidos na gestão hídrica, o que será apresentado no capítulo 2 deste trabalho.

Em resumo, pode-se dizer que a governança da água é um processo que demanda articulações entre diferentes stakeholders visando à promoção da prática participativa nas interfaces entre o Poder Público, o setor privado e a sociedade civil para a gestão participativa das águas. Portanto, é na governança que ocorre um exercício para o reequilíbrio das relações de forças (condição política), propiciando a atuação em redes (redefinição institucional) e promovendo a democracia participativa (condição histórico-cultural para as transformações 
necessárias) a fim de concretizar a mobilização da sociedade civil para que esta participe da gestão (THEYS, 2003).

Com esse cenário de concepções, pode-se dizer que a governança da água é compreendida como um processo democrático participativo que envolve governo, setor privado e sociedade civil visando à concretude de um contrato social, para que assim os diversos interesses dos stakeholders sejam contemplados e os serviços de água atendidos de maneira satisfatória, nos aspectos qualitativo e quantitativo, em todos os níveis da sociedade. Essa é a concepção de governança adotada para analisar o processo de participação no SCBH-CG para a governança da água, objeto de estudo desta pesquisa.

Entretanto, para a operacionalidade da governança da água, outro aspecto importante se faz presente: a sua governabilidade, o que será apresentado no item a seguir.

\subsection{GOVERNANÇA E GOVERNABILIDADE DA ÁGUA}

O conceito de governabilidade, assim como o de governança, não possui uma única definição, mas compreensões que estão em processo de discussão. Ambos são utilizados no campo político, econômico e científico, porém ainda é comum a confusão de conceitualização desses dois termos. Para esclarecer as distinções existentes, serão considerados os autores anteriormente referendados, contudo agora o foco recairá no que eles apresentam com relação à governabilidade da água; os pontos de vista desses autores são importantes na medida em que governança e governabilidade estão interligadas. Além disso, serão apresentadas as abordagens de outros autores para melhor elucidar essa discussão.

Para Hall (2002), governabilidade compreende a maneira pela qual o poder é exercido e a forma com que os recursos (natural, econômico e social) são manejados. Esse processo envolve a capacidade do governo em formular, fiscalizar e implementar políticas, respeitar o cidadão e sua relação com o Estado. Para o autor, uma governabilidade eficaz de recursos hídricos requer um compromisso conjunto do governo com os vários grupos da sociedade civil, particularmente aqueles que pertencem ao âmbito local, assim como o setor privado. 
Kaufmann, Kraay e Lobatón (2003) afirmam que governabilidade expressa a estabilidade política, a efetividade das políticas de governo, o controle da corrupção pública e o exercício do direito de participação no processo de tomada de decisão.

Para outros autores, como Kooiman et al. (2008), a governabilidade fornece uma base conceitual para avaliar e melhorar a governança interativa dos recursos naturais, ou seja, há uma relação estreita entre governança e governabilidade. Contudo, mesmo com esse posicionamento, os autores definem governabilidade como um equilíbrio entre a capacidade do sistema de governo e as necessidades do sistema a ser governado. Em outras palavras, governabilidade é a capacidade de organizar e realizar interações face à diversidade, à complexidade e à dinâmica entre os stakeholders para a gestão participativa, descentralizada e integrada de recursos hídricos.

Dessa forma, pode-se dizer que a noção de governança está centrada na noção de poder social, o qual faz a mediação das relações entre Estado e sociedade civil como espaço de construção de alianças e cooperação, mas que também é permeado por conflitos que decorrem do impacto das assimetrias sociais, e seus impactos no meio ambiente, e das formas de resistência, organização e participação dos diversos atores envolvidos (JACOBI, 2009).

Essa dinâmica pode ser chamada de poder local; o que para Dowbor (1999: 11) significa a "capacidade de autotransformação econômica e social" do município, envolvendo a descentralização, a desburocratização e a participação. Com isso se constata que há um processo na evolução da democracia participativa para a busca de instrumentos concretos de controle social.

Durante a realização da Conferência da ONU sobre os municípios e o meio ambiente, em 1990, foi discutido que as políticas ambientais só serão efetivamente implementadas quando as populações interessadas, município por município, decidirem defender a sua qualidade de vida. Assim, ocorre o processo de democratização das decisões na gestão pública, uma vez que há a intervenção do cidadão, fazendo com que o poder local seja um "eixo estratégico de transformação" para o desenvolvimento econômico e social; isso porque o instrumento básico do poder local é a participação social (DOWBOR, 1999).

Desse modo, percebe-se que a governabilidade nos regimes democráticos depende da adequação das instituições políticas em intermediar interesses entre Poder Público, privado e sociedade civil, e de mecanismos de responsabilização com transparência na gestão 
(accountability), que é um dos fatores para a boa governança, o que será discutido no item 2.3 deste trabalho.

A conectividade da governança e governabilidade, para Kooiman et al. (2008) que utilizam a concepção de governança interativa, enfatiza que a resolução dos problemas sociais se dará por meio de oportunidades criadas na interação dos atores do Poder Público, do setor privado e da sociedade civil, tendo a governabilidade como a base conceitual para avaliar e melhorar a governança dos recursos naturais.

Diante desse contexto, pode-se concluir que a governança da água é a estrutura legal definida, ou seja, as leis ambientais, os Conselhos de Recursos Hídricos, os Comitês de Bacias Hidrográficas e as Agências de bacia, com definição de papéis entre as instituições. Quanto à governabilidade, esta é compreendida como a capacidade política de governar, o que consiste em elaborar, implementar, fiscalizar e avaliar uma política pública, derivada da relação de legitimidade do Poder Público com a sociedade, a fim de realizar a governança da água.

Em síntese, pode-se dizer que a governabilidade da água é a interação das ações para que a governança aconteça, a qual é compreendida como o arcabouço legal que compõe a estrutura do Sistema Integrado de Gerenciamento de Recursos Hídricos, conforme instituído pela Política Nacional de Recursos Hídricos (Lei n. ${ }^{\circ}$ 9.433/97) ${ }^{4}$.

Mas, quais critérios utilizar para analisar a efetividade da governança? Ou, o que determina uma boa governança, se não há um conceito definido, mas sim concepções, como anteriormente apresentadas? No item a seguir, há a apresentação desses critérios para a compreensão dessa efetividade.

\subsection{FATORES PARA A BOA GOVERNANÇA DA ÁGUA}

$\mathrm{Na}$ literatura pesquisada, alguns atores mencionam fatores que podem contribuir para a efetividade da governança e que, quando não são concretizados, levam ao seu enfraquecimento.

Conforme apresentado por Rogers e Hall (2003), algumas situações podem afetar a interação entre os stakeholders e assim prejudicar a governança, tais como: a) Estado fraco

\footnotetext{
${ }^{4}$ Brasil (1997).
} 
(modelo onde o Estado deixa de ser o estruturante e passa a ser o regulador) e problemas na estrutura administrativa pública; b) dificuldades nas definições e mensurações (de dados e informações); c) concentração populacional em áreas urbanas; d) a não cooperação entre os atores; e) ausência de estratégias coletivas; e f) a não continuidade na implementação das políticas públicas.

Pressupõe-se, portanto, que para concretizar a governança é preciso mudanças estruturais, com a contribuição dos diversos atores envolvidos na questão, setor econômico, político e social, a fim de que se tenha a governança com princípios éticos e participativos, e que seja integrada e comunicativa. Sua efetividade se dará por fatores como: responsabilidade com transparência (accountability), abertura, comunicabilidade, participação, coerência, sustentabilidade, equidade, eficiência, integração e ética. Ao que se refere a accountability, este é um termo sem exata tradução para o português, mas remete à responsabilização no processo de prestação de contas com autoavaliação do que foi realizado, aspecto fundamental para a boa governança.

Rogers e Hall (2003) e UNESCO (2006) utilizam-se dos mesmos critérios para avaliar a boa governança da água, no entanto deve existir uma combinação entre estes. São eles:

a) Abertura e transParênCia: utilização de linguagem acessível ao público em geral para compartilhar informações com a sociedade, a fim de estabelecer um aumento da confiança no processo de tomada de decisão, favorecendo a concretização dos acordos, visto terem sidos realizados de forma transparente;

b) InCLUSÃo E COMUNICAÇão: a efetividade de uma política demanda participação, que pode ocorrer de forma direta ou por meio de organizações representantes de seus interesses. Para isso, faz-se necessário um processo de mobilização social com liberdade para associar-se e expressar-se;

c) COERÊNCIA E INTEgRAÇão: a complexidade das questões hídricas demandam políticas e ações coerentes, o que requer liderança política e forte responsabilidade por parte dos stakeholders. Quanto à integração, a governança da água melhora a efetividade da gestão integrada de recursos hídricos, por considerar todos os usos e usuários da água e a interconectividade de seus impactos;

d) EQUiDADE E ÉTICA: todos têm direito a melhorar ou manter seu bem-estar com equidade e princípios éticos entre os vários interesses dos stakeholders; 
e) ACCountabiLity: clareza dos papéis tanto no legislativo quanto no executivo, e cada instituição deve ter responsabilidade para o que lhe cabe fazer, tendo sempre clareza dos mecanismos acordados entre os tomadores de decisão, governo, setor privado e organizações da sociedade civil;

f) EFICIÊNCIA: aqui é considerada para além do aspecto econômico, pois engloba os aspectos político, social e ambiental que precisam estar em equilíbrio;

g) ReSPONSABILIDADE E SUSTENTABILIDADE: as políticas devem atender às necessidades básicas demandadas com clareza de objetivos e com responsabilidade, para atender aos usuários das gerações presentes e futuras.

Mas afinal, isso tudo se resume em quê? Para a boa governança, é preciso ética, participação, integração e comunicação, o que enfatiza a necessidade de ter abertura e transparência, com linguagem compreensível entre todos os participantes, a fim de que os envolvidos se sintam corresponsáveis, tenham confiança e legitimem o processo de governança, assegurando a participação em todo o processo de gestão, desde a concepção até a sua implementação.

Para ter a boa governança da água é preciso definir arranjos institucionais/redes de atuação com real participação conjunta dos stakeholders, pois gerenciar a água é para além de seu sentido físico, é considerar também seu contexto socioeconômico e as decisões macropolíticas, o que demanda a necessidade de gerar maior grau de consenso sobre as questões debatidas. Em outras palavras, para a boa governança é preciso que cada área, ao pensar a governança, leve em consideração suas peculiaridades, tais como habilidades, limitações e expectativas envolvidas, ou seja, o arranjo sócio-institucional necessário; no qual certamente aparecerão as incompatibilidades das práticas antigas versus as recentes (SOLANES; JOURAVLEV, 2006).

Desse modo, uma boa governança é a capacidade de bem governar, o que significa ter a habilidade em implementar políticas públicas sustentáveis e que sejam socialmente aceitas no processo democrático participativo. 


\subsection{A GESTÃo dOS RECURSOS HídRICOS NO BRASIL: Novo PARAdigMa}

O novo paradigma de gestão compartilhada de recursos hídricos no Brasil é decorrente da preocupação com sua qualidade e quantidade, somada ao processo de democratização da sociedade brasileira que busca um novo arcabouço institucional para a gestão descentralizada, participativa e integrada de recursos hídricos, com a finalidade de satisfazer as necessidades do presente, sem comprometer o direito das futuras gerações e suas perspectivas de evolução socioeconômica, num cenário de progressiva escassez da água.

No passado, a responsabilidade para se obter o equilíbrio da gestão de recursos hídricos era concentrada no Poder Público, mas com a mudança de paradigma cabe às entidades públicas, bem como a todos os componentes sociais e aos usuários de recursos hídricos.

A mudança de paradigma ocorre devido à necessidade de melhoria da qualidade das águas associada às práticas participativas na gestão, que direcionam para uma nova qualidade de cidadania por abrir espaços de participação sociopolítica. Nesse novo paradigma a gestão se dá por bacias hidrográficas, que são as unidades regionais de planejamento e gestão das águas, que se tornam importantes no Brasil devido ao aumento dos efeitos de degradação ambiental sobre a disponibilidade de recursos hídricos. "A bacia hidrográfica compreende o território que pelas suas características topográficas, geológicas, de solo, vegetação e águas, recebe e conduz todas as que escoam em sua superfície para um certo corpo de água." (SRH/MMA, 2000 apud THEODORO, 2002: 20).

O acesso à água em quantidade e qualidade satisfatória à manutenção da vida é uma preocupação ambiental em escala internacional ${ }^{5}$, pois sua distribuição encontra-se de maneira desproporcional na Terra e os múltiplos usos, à medida que se tornam mais intensos, geram diversos conflitos. O surgimento desses conflitos, como no caso do Brasil, se dá devido à complexidade da administração da água, isso porque há diversas entidades públicas, federais, estaduais e municipais, e privadas participando do sistema integrado visando à adoção dos princípios gerais orientadores da política e da gestão de recursos hídricos (THEODORO, 2002).

\footnotetext{
${ }^{5}$ Para o aprofundamento na leitura sobre o processo no plano internacional, sugere-se a leitura de Ribeiro (2009).
} 
Etimologicamente, 'conflito' é uma palavra de origem latina que quer dizer “choque, embate, encontro, combate, luta" (HOUAISS, 2001). Nele está presente a ideia de contradição, de oposição e de desordem. Os conflitos são intrínsecos à condição humana e estão presentes na mente e nas relações dos homens. Eles estão em vários aspectos da vida cotidiana, como no trabalho, na família, entre nações e relações institucionais (SOARES, 2008).

Quanto à definição do termo 'conflitos ambientais', Little (2001: 107) apresenta-o como

disputas entre grupos sociais derivadas dos distintos tipos de relação que eles mantêm com seu meio natural. O conceito socioambiental engloba três dimensões básicas: o mundo biofísico e seus múltiplos ciclos naturais, o mundo humano e suas estruturas sociais, e o relacionamento dinâmico e interdependente entre os dois mundos.

Para Barbanti Junior (2002: 5), "conflito não é algo dado em si, existente, mas sim construído nas relações sociais. Desta forma, a personalidade do indivíduo é uma dimensão fundamental no processo de negociação e nos resultados dele."

Essa situação demanda gerenciamento integrado e compartilhado, sendo fundamental a participação social para despertar no cidadão a corresponsabilização no cuidado desse bem comum e na implementação das demais políticas públicas, pois a gestão dos recursos hídricos está interligada com as questões políticas, econômicas, culturais e sociais, exigindo uma atuação interdisciplinar. Nesse sentido, Sachs (2002) afirma que esse universo demonstra a complexidade das questões ambientais e demanda a contribuição das várias áreas do conhecimento para administrar a relação do ser humano com o meio natural, de forma integrada, numa perspectiva de desenvolvimento sustentável, o que gera conflitos.

Esse desafio de gestão compartilhada é complexo, uma vez que pressupõe uma mudança fundamental de atitude, por parte da sociedade, na forma como a água é utilizada, gerida e valorizada.

Cabe ressaltar que essa gestão é uma decisão política. Assim, a condição fundamental para a gestão compartilhada de recursos hídricos é a motivação política para a implantação do sistema de gestão, com o objetivo de obter os benefícios econômicos e sociais, com a mínima degradação ambiental, respeitando os princípios dessa política. 
No Brasil a legislação apresenta o Sistema Nacional de Gerenciamento de Recursos Hídricos (SINGREH), que é resultado de um dispositivo constitucional que foi regulamentado pela Lei Federal n. ${ }^{\circ}$ 9.433/97, ou Lei das Águas (BRASIL, 1997). Essa Lei traz os paradigmas da descentralização, utilização de instrumentos econômicos para a gestão e participação pública no processo de tomada de decisão, tendo em vista que a água é um recurso natural que define o desenvolvimento que uma região, país ou sociedade pode alcançar.

Ao que diz respeito à organização institucional, a gestão de recursos hídricos no Brasil, após a aprovação da Lei n. ${ }^{\circ}$ 9.433/97, passou a ter um aspecto fundamental: a criação de um sistema institucional para que a União, os Estados, os municípios, os usuários de recursos hídricos e a sociedade civil organizada se articulassem e negociassem a gestão de recursos hídricos nas bacias hidrográficas de forma compartilhada (PEREIRA, 2003) ${ }^{6}$.

Esse processo de gestão em bacias hidrográficas de forma descentralizada, participativa e integrada encontra-se em processo de construção gradual desde a década de 1990; sendo que este está sendo efetivado pelos caminhos da democracia participativa e não apenas representativa (SANTOS; AVRITZER, 2003).

Essa conquista é atribuída à sociedade civil organizada que demonstra sua potencialidade enquanto sujeitos sociais organizados, que se reúnem em prol de causas comuns para transformar a gestão pública autoritária em gestão democrática participativa (JACOBI, 2000), propiciando a cidadania ativa na relação Estado-sociedade civil.

A inovação institucional ocorreu no aspecto de descentralizar o processo de gestão, que passou a integrar os atores: o Poder Público, usuários e organizações civis. Isso porque, todos estão envolvidos e têm interesse na disponibilidade da água; logo, possuem atribuições e responsabilidades para a sustentabilidade hídrica.

\footnotetext{
${ }^{6}$ Com base neste documento, a governabilidade de recursos hídricos é a implementação dos instrumentos de gestão da água, a saber: plano de recursos hídricos ou planos de bacia hidrográfica, o enquadramento dos corpos de água em classes, a outorga dos direitos de usos da água, a cobrança pelo uso da água e o sistema de informações sobre recursos hídricos (PEREIRA, 2003).
} 


\subsubsection{Política Nacional de Recursos Hídricos (Lei Federal N. * 9.433/97)}

As Constituições Federais do Brasil de 1946 e 1967 apresentavam o processo de centralização das competências jurídicas relativas à água na esfera da União. A Constituição de 1946 regulamentava a utilização dos recursos naturais visando à sua exploração econômica e a Constituição de 1967 reforçava o aspecto da exploração econômica e estabelecia regras genéricas sobre o uso da água (SÃO PAULO, 1995).

O regime político no Brasil até o final da década de 70 foi marcado pelo predomínio de ações centralizadoras e de decisões impostas à sociedade. A partir da década de 80, esse quadro é revertido e, após muita luta e longo período de discussão, foi promulgada a Constituição Federativa do Brasil em 1988; a qual foi decisiva para a instituição de um Estado democrático de direito: direitos individuais, à liberdade, à luta pela igualdade e pelo bem-estar social, acompanhado pelo desenvolvimento.

Com base no art. 21 da Constituição Federal de 1988, foi promulgada a Lei n. ${ }^{\circ}$ 9.433/97, que obriga as autoridades federais a criar o Sistema Nacional de Gestão dos Recursos Hídricos. A Constituição Federal de 1988 também divide as águas em dois únicos domínios, o federal e o estadual, inibindo que a água seja de domínio privado e/ou municipal ${ }^{7}$. Essa divisão constitucional das águas implica que os estados também devem criar seu próprio sistema de gestão dos recursos hídricos e integrá-los ao sistema nacional, conforme estabelece a Lei n. ${ }^{\circ} 9.433 / 97$.

Diante disso, os estados iniciaram suas reformas, com amplo debate, tendo por referência a aplicabilidade da Lei n. ${ }^{\circ}$ 9.433/97. Em alguns estados, como Rio Grande do Sul, São Paulo e Ceará, a reforma foi iniciada antes de a referida Lei ser discutida e aprovada.

É importante destacar que a Lei n. 9.433/97, ou Lei das Águas, institui a Política Nacional de Recursos Hídricos (PNRH) e cria o Sistema Nacional de Gerenciamento de Recursos Hídricos (SINGREH). Os instrumentos de gestão preconizados pela Lei das Águas e

\footnotetext{
${ }^{7}$ De acordo com a Constituição Federal aprovada em 1988, constituem-se bens da União "lagos, rios e qualquer corrente de água em território federal ou compartilhado por um ou mais Estados, servindo de fronteira com outro país." (BRASIL, 2003). Os demais cursos d'água e as águas subterrâneas são de domínio dos estados. Assim, a gestão de recursos hídricos no Brasil apresenta desafios semelhantes à gestão de bacias de rios transfronteiriços compartilhados por países autônomos. Para se alcançar uma boa gestão de recursos hídricos, é necessária uma articulação entre todos os seus entes federados (BRAGA et al. 2008).
} 
disponíveis para o SINGREH são: plano de bacia hidrográfica, enquadramento dos corpos d'água, outorga, cobrança pelo uso dos recursos hídricos e sistema de informações.

O plano de bacia hidrográfica requer do sistema de informação dados sobre a disponibilidade de água em quantidade e qualidade, além das demandas por múltiplos usos agregadas por bacia hidrográfica. Os planos de bacia são planos diretores que visam fundamentar e orientar a implementação da política de recursos hídricos em nível de bacias hidrográficas, definindo os usos prioritários e o programa de investimento para o desenvolvimento, uso sustentável, recuperação e conservação dos recursos hídricos da bacia.

O enquadramento tem por finalidade determinar níveis de qualidade ao longo do tempo nos diversos trechos da bacia hidrográfica em razão dos usos e dos programas e metas para a consecução desses objetivos. As definições nele previstas afetam diretamente a outorga que se dará pelas vazões de diluição, as quais são, por sua vez, função dos níveis de qualidade estabelecidos.

A outorga é um instrumento que tem por objetivo assegurar o controle quantitativo e qualitativo dos usos da água. É o direito de acesso à água, ou a habilitação para o seu uso. Para sua implementação, a outorga demanda do sistema de informações dados relativos à disponibilidade hídrica em quantidade e qualidade, e dos usuários a montante e jusante do ponto de autorização.

A cobrança, além dos seus objetivos de racionalização do uso da água e de estímulo a não poluir, é o instrumento de gestão que permite o aporte de recursos para financiar o programa de investimentos da bacia.

A compensação aos municípios: o artigo 24 da Lei n. ${ }^{\circ} 9.433 / 97$ foi vetado com a justificativa de não ter apoio na Constituição Federal, mas esse instrumento previa a compensação financeira aos municípios que tivessem áreas inundadas por reservatórios ou sujeitas a restrições de uso do solo com a finalidade de proteção de recursos hídricos, visando ao ressarcimento da comunidade pela provação das rendas futuras que os terrenos inundados ou sujeitos a restrições de uso do solo poderiam gerar (SÃO PAULO, 2004).

O sistema de informação tem por objetivo principal produzir, sistematizar e disponibilizar dados e informações que caracterizem as condições hídricas da bacia em termos de quantidade e qualidade da água nos diversos usos (BRAGA et al., 2008). 
O Comitê de Bacia Hidrográfica $(\mathrm{CBH})$ é um órgão colegiado constituído pelos representantes dos governos municipais, estaduais e federal, pelos representantes dos usuários e da sociedade civil organizada ${ }^{8}$. Suas atribuições, conforme art. 38 da Lei, são:

i. promover o debate das questões relacionadas a recursos hídricos e articular a atuação das entidades intervenientes;

ii. arbitrar, em primeira instância administrativa, os conflitos relacionados aos recursos hídricos;

iii. aprovar e acompanhar o Plano de Recursos Hídricos da bacia;

iv. estabelecer os mecanismos de cobrança pelo uso de recursos hídricos e sugerir os valores a serem cobrados;

v. estabelecer critérios e promover o rateio de custo das obras de uso múltiplo, de interesse comum ou coletivo. (BRASIL, 1997).

Dessa forma fica organizada a gestão de recursos hídricos no âmbito nacional, que passa a ser baseada em novos tipos de organização, ou seja, passou a ser gestão compartilhada do uso da água, com princípios norteadores que preconizam a gestão integrada, descentralizada e participativa. Em 2008 eram 120 comitês de bacias estaduais e seis federais, mas em sua maioria ainda não tinha operacionalizado o sistema por completo, deixando em aberto a execução dos instrumentos de gestão em sua totalidade para o completo funcionamento do sistema.

Quanto ao consumo de água no Brasil, cerca de 70\% são destinados à irrigação para produção de alimentos; o abastecimento urbano representa 11\%; a dessedentação animal, 11\%; o industrial, 7\%; e o abastecimento rural, 2\% (ANA, 2007 apud BRAGA et al., 2008).

Apesar de o Brasil liderar a disponibilidade de água doce no mundo com $12 \%$ do total, existem problemas locais de oferta de água para os diferentes usos. Esses problemas decorrem de elevadas demandas quantitativas em relação à disponibilidade e do comprometimento da qualidade das águas pela poluição. Em bacias hidrográficas de regiões metropolitanas, como São Paulo, há a necessidade de transportar água de bacias vizinhas, como o que vem ocorrendo com $50 \%$ da água de abastecimento urbano que vêm da bacia do Rio Piracicaba, deixando de estar disponíveis para a Região Metropolitana de Campinas e Piracicaba.

Os princípios sobre os quais se baseia a Política Nacional de Gestão de Recursos Hídricos podem ser resumidos da seguinte forma: reconhecimento da água como um bem

\footnotetext{
${ }^{8}$ Cabe ressaltar que na Política Estadual de Recursos Hídricos de São Paulo, a composição dos CBHs se dá por representantes do Estado, dos municípios e da sociedade civil, o que difere da composição nacional.
} 
público dotado de valor econômico; garantia do uso múltiplo das águas; prioridade do uso dos recursos hídricos em situações de escassez para o consumo humano e dessedentação de animais; e adoção da bacia hidrográfica como unidade territorial de planejamento e gestão das águas: gestão descentralizada e com a participação dos diferentes níveis do Poder Público, dos usuários e da sociedade civil no processo de tomada de decisão.

A Política de Recursos Hídricos é orientada pelas seguintes diretrizes gerais de ação: gestão sistemática de recursos hídricos sem dissociação dos aspectos de quantidade e de qualidade; adequação da gestão de recursos hídricos às diversidades físicas, bióticas, demográficas, econômicas, culturais e sociais das diversas regiões do país; articulação da gestão de recursos hídricos com a gestão ambiental; articulação do planejamento dos recursos hídricos com o dos setores usuários e com os planejamentos regionais, estaduais e nacional; articulação da gestão de recursos hídricos com a gestão do uso do solo; e integração da gestão das bacias hidrográficas com a dos sistemas estuarinos e das zonas costeiras. Para implementar esse sistema, que é complexo, foi criada a ANA (Agência Nacional de Água) (Lei n. ${ }^{\circ}$ 9.984/2000) ${ }^{9}$ com a competência de implementar e coordenar o Sistema Nacional de Gerenciamento de Recursos Hídricos.

A gestão compartilhada de recursos hídricos demanda a compatibilização dos diversos conflitos de interesses. Requer a criação de ambientes institucionais abertos à negociação para resolução e superação dos problemas. Esses ambientes são formados por múltiplos atores que buscam a convergência de objetivos; o entendimento das questões e desafios envolvidos; a criação de laços de confiança por meio de um processo de gestão ético, transparente e democrático, que conduza à equidade, racionalidade e eficiência na tomada de decisões; e a construção de um sentido de identidade da bacia, de corresponsabilidade e codependência.

Esse mosaico institucional demonstra que os atores locais estão interessados no desenvolvimento de seus recursos hídricos e em sua proteção e recuperação. Segundo seus interesses específicos, e com maior ou menor intensidade, todos esses organismos têm criado oportunidades de informação, capacitação e discussão quanto aos princípios e instrumentos de gestão de recursos hídricos (BRAGA et al., 2008).

Diante da diversidade de ritmos e capacidades de cada sistema de gestão no Brasil, a implementação da gestão compartilhada está sendo realizada de forma gradativa. Neste

\footnotetext{
${ }^{9}$ Brasil (2000).
} 
trabalho o recorte será no Estado de São Paulo, mais especificamente no SCBH-CG durante o processo de criação da Lei Específica da Guarapiranga.

\subsubsection{Política Estadual de Recursos Hídricos do Estado de São Paulo (Lei N. ${ }^{07.663 / 91)}$}

A Constituição Estadual de São Paulo de 1989, em seus artigos 205 a 213, assegura a criação de um sistema integrado de gerenciamento dos recursos hídricos, congregando órgãos estaduais, municipais e a sociedade civil para a utilização racional das águas com prioridade para o abastecimento público, segundo um plano; o aproveitamento múltiplo dos recursos hídricos; a proteção das águas contra ações que possam comprometer o seu uso atual e futuro; e a gestão descentralizada, participativa e integrada, sendo o Estado o incentivador da adoção, pelos municípios, de medidas que visem proteger a quantidade e a qualidade das águas (SÃO PAULO, 1989).

Em São Paulo o processo para legislação hídrica, com a nova dominialidade da CF 1988, antecipou-se ao sistema da gestão federal. A Constituição Estadual, em 1989, dedica uma seção no capítulo de meio ambiente exclusiva aos recursos hídricos, prevendo a instituição de um sistema de gestão de forma descentralizada, participativa e integrada. O referido Estado, em 1991, aprovou a Lei n. 7.663 que institui a Política Estadual de Recursos Hídricos no Estado (SÃO PAULO, 1991), antes mesmo da aprovação da Política Nacional de Recursos Hídricos, Lei n. ${ }^{\circ} 9.433 / 97$.

A Lei paulista de recursos hídricos prevê um colegiado de gestão denominado Comitês de Bacias Hidrográficas (CBHs), que são espaços colegiados de gestão compartilhada entre o Poder Público e a sociedade civil. Os CBHs são formados por representantes dos órgãos do Governo do Estado e dos municípios, sendo os representantes da sociedade civil eleitos entre os representantes de organizações sociais, com igual número por segmento. O funcionamento do sistema é um processo contínuo e interativo das três instâncias: os comitês de bacia definem as prioridades regionais, que são sistematizadas no plano estadual, transformado em lei; os recursos financeiros são, então, destinados às bacias e administrados por uma agência local, segundo as diretrizes dos respectivos comitês (COMITE-AT, 2008). 
O Estado está dividido em 22 unidades de gerenciamento de recursos hídricos (UGRHIs) e possui $21 \mathrm{CBHs}$ (Figura 1). Cada bacia hidrográfica precisa elaborar seu plano de recursos hídricos, que tem por objetivos:

\begin{abstract}
Assegurar água de boa qualidade e na quantidade adequada a toda a população, sendo necessário, para tanto, a proteção dos mananciais superficiais e subterrâneos, a conservação e a utilização racional da água; Recuperar e conservar a qualidade dos corpos de água da bacia; Implantar sistemas eficientes de drenagem e controle de cheias, por meio e medidas estruturais e não-estruturais. (SIGRH, 2008).
\end{abstract}

Para isso, "os governos são responsáveis pela criação de um gerenciamento hídrico integrado e por assegurar a conservação dos recursos e o papel social das águas." (TUNDISI, 2003: 140).

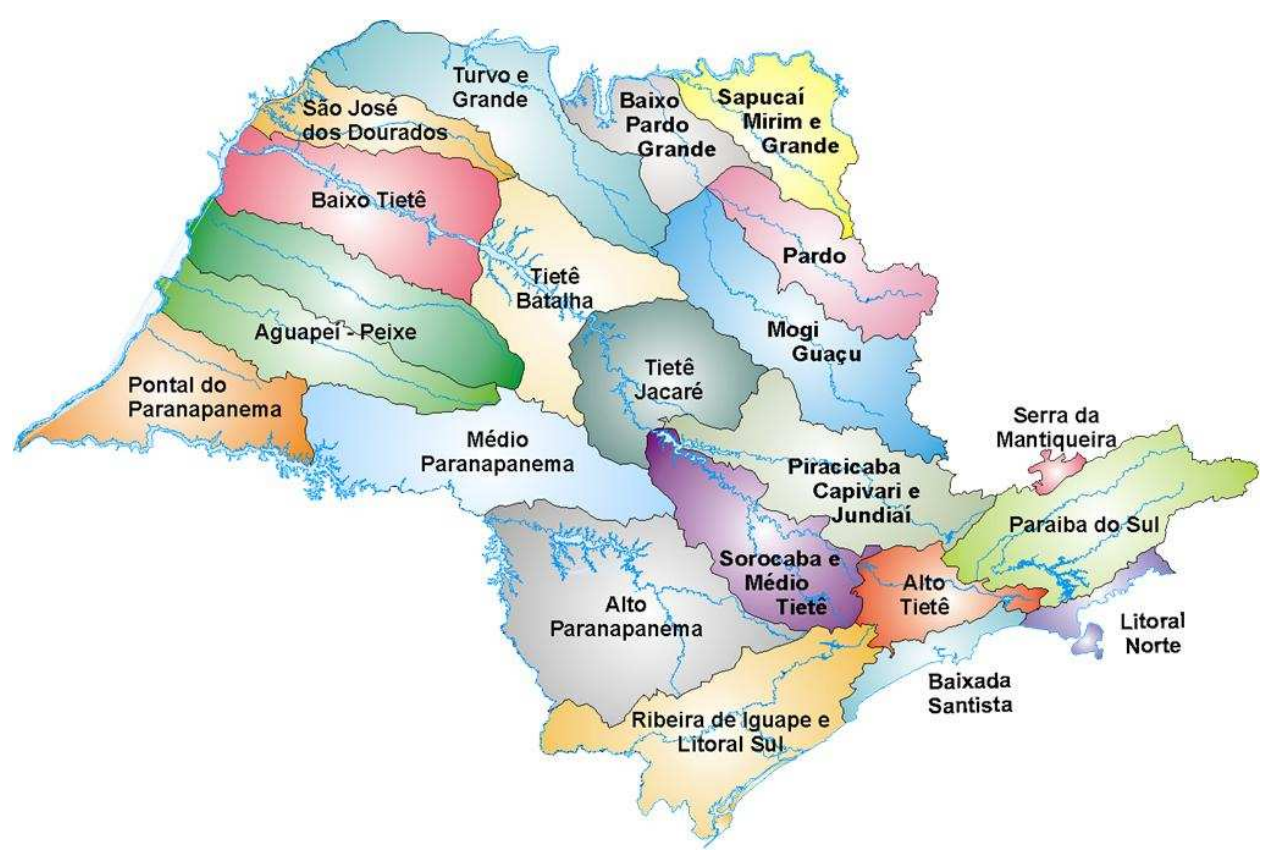

FigURA 1 - Mapa dos comitês de bacias hidrográficas do Estado de São Paulo. FONTE: ISA (2008a). 


\subsubsection{GESTÃo URBANA DAS ÁGUAS E SEUS DESAFIOS}

A crescente urbanização é resultado de um conjunto de fatores políticos, sociais, econômicos, tecnológicos e artísticos, que, ocorridos principalmente na segunda metade do século XX, têm determinado alterações significativas nos padrões de vida da sociedade moderna, o que reflete no aumento constante da procura de água e no lançamento de quantidades cada vez maiores de resíduos provenientes de suas atividades, no ambiente. Outros aspectos negativos das aglomerações são os problemas de saúde, os meios de transportes inadequados, destinação dos resíduos das atividades de produção e de consumo, os quais aumentam exponencialmente com o tamanho das metrópoles (ROMERO; PHILIPPI JUNIOR; BRUNA, 2004).

Nessas áreas, o crescimento populacional acarreta mudanças no uso do solo de diferentes naturezas; mudanças essas que estão vinculadas a processos de especulação fundiária, induzindo à conversão do uso não urbano (vegetação natural ou uso agrícola) para atividades ou infraestrutura urbana (como vias de transporte, reservatórios de água e outros).

O Brasil, durante o século XX, passou por um intenso processo de urbanização. Em 1950, a população urbana era de $36 \%$, já no ano de 2000 esse índice foi para $81 \%$, o que significa que as áreas urbanas, que somavam 19 milhões de pessoas em 1950, alteraram-se para 138 milhões de pessoas em 2000 (CARMO, 2005).

Esse cenário demonstra que a demanda e a pressão sobre os recursos hídricos estão estreitamente vinculadas aos usos e à ocupação do solo, logo o planejamento e a gestão dos recursos hídricos devem estar articulados com o planejamento e a gestão territorial. Isso porque o uso atribuído ao território interferirá diretamente na disponibilidade hídrica, ou o tipo de ocupação do território se dará pela riqueza hídrica disponível.

Neste trabalho é atribuída importância é atribuída ao contexto das bacias hidrográficas densamente urbanizadas, como ocorre na bacia do Alto Tietê, Região Metropolitana de São Paulo, onde é urgente a concretude de processos de articulação e integração entre as práticas de gestão de recursos hídricos e de gestão urbana do território.

Quando se trata de bacias urbanas, densamente ocupadas, a integração perpassa o aspecto setorial, que está relacionado aos diferentes usos na bacia, demandando por equilíbrio entre o uso industrial, abastecimento público, esgotamento e drenagem pluvial, e por sua 
articulação com setores que influenciam sobre a quantidade e qualidade das águas, mas que não se relacionam diretamente com a competência da gestão de bacias, como é o caso do setor de habitação e transporte. Estes são decisivos na determinação dos processos de uso e ocupação do solo, pois interferem na preservação de áreas de mananciais. No entanto, é preciso que haja cooperação interinstitucional para que aconteça a gestão integrada de recursos hídricos. Outro aspecto é o territorial, cujo agrupamento jurisdicional do território, ou seja, a divisão administrativa do território, não condiz com a divisão territorial que compõe a bacia hidrográfica, representando um desafio na integração das políticas públicas naquela bacia, como a cooperação intergovernamental entre diferentes agregações territoriais. Isso pode ser visto na RMSP, que é composta por 39 municípios, dos quais 35 compõem a bacia do Alto Tietê (SILVA; PORTO, 2003).

Nos caminhos da integração da gestão urbana e das águas, Silva e Porto (2003) destacam quatro desafios com base na experiência da bacia hidrográfica do Alto Tietê, a saber:

a) Integração entre o sistema de gestão e as atividades diversas relacionadas ao uso da água, visando à gestão conjunta de qualidade e quantidade;

b) Integração territorial no planejamento e gestão urbana com aplicação de medidas preventivas, evitando o agravamento da disponibilidade hídrica;

c) Articulação reguladora com sistemas setoriais, não diretamente usuários de recursos hídricos, como habitação e transporte, porque a ocupação das áreas de proteção de mananciais interfere na sustentabilidade hídrica;

d) Articulação com bacias vizinhas, pois o processo de importação de vazões e de exportação de águas utilizadas na bacia demanda acordos com outras áreas territoriais.

Como foi possível observar, esses desafios exigem articulação institucional com os sistemas de meio ambiente e de planejamento metropolitano, e com os poderes públicos municipais envolvidos na região da bacia hidrográfica, o que significa desafios complexos, pois não podem ser enfrentados somente pelo sistema de gestão de recursos hídricos. 
Além desses desafios, Gutiérrez (2006) apresenta outro limite da gestão compartilhada: conseguir a interação e colaboração entre atores estatais e atores sociais para garantir a viabilidade de políticas públicas participativas, por ser dessa forma que resultados eficientes são produzidos. Cabe enfatizar que, ao avaliar a execução da gestão compartilhada no Brasil, os resultados ainda não são satisfatórios, conforme projetado na Política Nacional de Recursos Hídricos (Lei n. ${ }^{\circ}$ 9.433/97); isso ocorre porque todos os instrumentos que deveriam sustentar uma gestão integrada e eficiente de recursos hídricos não foram implementados integralmente. "Reverter essa situação equivale a enfrentar a tarefa múltipla de conseguir a sustentabilidade técnica, financeira e política dos comitês." (GUTIÉRREZ, 2006: 105). Portanto, a decisão participativa e democrática precisa de sólida base técnica e a proposta técnica precisa de decisão política por parte do comitê, a qual está sujeita a decisões financeiras e políticas dos órgãos estaduais pertinentes.

Mas em que consiste a sustentabilidade técnica, financeira e política da gestão hídrica?

A sustentabilidade técnica e financeira remete ao aval político para completar a reforma do sistema de gestão, e quando não ocorre prejudica a capacidade do comitê de bacia de executar planos e programas de ação, afetando a legitimidade e funcionamento do comitê. Quanto à falta de apoio político, isso pode se dar pelas restrições orçamentárias governamentais e pela não prioridade do tema água diante de outros temas, tais como a pobreza, o desemprego e a insegurança (GUTIÉRREZ, 2006).

A gestão compartilhada de recursos hídricos tem por fundamento o uso sustentado dos recursos. Entretanto, para isso, é preciso uma abordagem multissetorial para a gestão de demanda. Assim sendo, a gestão compartilhada objetiva gerir a demanda de recursos hídricos de forma a equilibrar a disponibilidade encontrada com os usos múltiplos da água (SILVA; PORTO, 2003). Quando se fala em gestão de recursos hídricos, compreende-se o equacionar e o resolver as questões de escassez relativa aos recursos hídricos fazendo uso adequado para a otimização dos recursos em benefício da sociedade (BARTH, 1987 apud SETTI et al., 2000).

A gestão da água é caracterizada pela necessidade de equacionar a sua multissetorialidade, que decorre de um conjunto de aspectos que se acentuam em grandes aglomerados urbanos, como é o caso da Região Metropolitana de São Paulo (RMSP). Essa conjuntura gera conflitos quanto à destinação do uso, por exemplo, a retirada de água para a irrigação; conflitos de disponibilidade qualitativa, devido à poluição dos corpos d'água; e conflitos de disponibilidade quantitativa, devido ao uso intensivo desse recurso. Para isso, no entanto, carece de uma abordagem interdisciplinar, com a participação da sociedade civil, 
para o melhor aproveitamento desse recurso e para que haja o comprometimento consciente da população com as medidas a serem implementadas.

Esse novo sistema de gestão compreende todos os usos da água, o que demanda por uma gestão compartilhada entre todos os setores envolvidos. A organização desse sistema tem por base o Comitê de Bacia Hidrográfica $(\mathrm{CBH})$, o qual, conforme a Política Estadual de Recursos Hídricos de São Paulo, tem a sua composição constituída por representantes do Poder Público estadual, municipal e entidades da sociedade civil.

No art. 39 da Lei Federal n. ${ }^{\circ}$ 9.433/97, os CBHs são compostos por representantes da União $^{10}$, dos estados e do Distrito Federal cujos territórios se situem, ainda que parcialmente, em suas respectivas áreas de atuação; dos municípios situados, no todo ou em parte, em sua área de atuação; dos usuários das águas de sua área de atuação; e das entidades civis de recursos hídricos com atuação comprovada na bacia (BRASIL, 1997). Vale ressaltar que, tanto na política nacional como na estadual de São Paulo, está garantida a participação de organizações da sociedade civil vinculadas aos recursos hídricos (BRASIL, 1997; SÃO PAULO, 1991).

Esse novo paradigma de gestão de recursos hídricos implicou em mudança, relacionada a quem tem acesso ao poder de formular e implementar políticas, passou-se de uma administração setorial centralizada a uma gestão integrada, que é, ao mesmo tempo, participativa e descentralizada. Essa mudança ocorre com a finalidade de disciplinar o uso econômico da água, visando à recuperação, proteção, conservação e ao uso racional dos recursos hídricos. A implantação e a operacionalização desse sistema de gestão e seus instrumentos em nível de bacia hidrográfica requerem o enfrentamento e a superação de desafios, conforme apresentados por Pereira (2003):

a) IMPLEMENTAÇÃo DE UMA GESTÃo COMPARTILHADA: requer que os atores envolvidos, público, privados e sociedade civil organizada, formem parcerias para compartilhar o poder de decisão e a definição de estratégias e metas entre os diferentes atores, a fim de responder ao novo paradigma de gestão integrada, descentralizada e participativa de forma democrática. Isso pressupõe mecanismos

\footnotetext{
${ }^{10}$ A participação da União nos Comitês de Bacia Hidrográfica com área de atuação restrita a bacias de rios sob domínio estadual, dar-se-á na forma estabelecida nos respectivos regimentos.
} 
de convivência e não de subordinação, que permite articular a atuação dos órgãos gestores em nível da bacia hidrográfica.

b) Construção de uMa lógica territorial de GeStão: significa ir além da gestão da água na bacia hidrográfica em referência, mas sim buscar a lógica territorial de gestão integrada dos usos múltiplos. A integração dos diversos setores para a gestão compartilhada da água é imprescindível para que esta ocorra de forma participativa e democrática.

c) OPERACIONALIZAÇÃo E FORTALECIMENTO DO COMITÊ DE BACIA: buscam definir os mecanismos de funcionamento e a sustentabilidade do mesmo em seu aspecto técnico, financeiro e administrativo, com o intuito de que seja implementada as decisões. Na nova concepção de gestão compartilhada, o conhecimento técnico-científico deve ser colocado à disposição do $\mathrm{CBH}$ de forma eficiente e democrática.

d) Estabelecimento de REgRAS de CONVIVÊNCIA NO ÂMBITO dos COMITÊS: a atuação dos comitês, arena de negociação para a gestão compartilhada, precisa de clareza, transparência e explicitação dos propósitos, subsidiados pelo conhecimento técnico para a tomada de decisões. Nessa arena, os conflitos surgem, sendo necessária a construção de consensos. A tarefa é desafiadora, pois os interesses ora são individuais ora são corporativos.

e) APERFEIÇOAMENTO DA LEGISLAÇÃo: trata-se de compatibilizar a legislação da União com a dos estados, de forma que os procedimentos técnicos, jurídicos e administrativos sejam convergentes para a implementação dos instrumentos das Políticas Nacional e Estadual de Recursos Hídricos. Essa questão impõe um dos maiores desafios para o gerenciamento integrado dos recursos hídricos do país, sobretudo diante da diversidade política, econômica, social e ambiental das regiões brasileiras que se reflete nos ritmos de regulamentação e implementação dos sistemas estaduais de gestão de recursos hídricos, diferenciados de um ente federado para outro.

A gestão compartilhada de recursos hídricos requer, portanto, a negociação de conflitos de interesses entre os diferentes atores e demandas. Requer a criação de ambientes institucionais adequados à resolução de conflitos, à negociação e à superação das lacunas 
existentes nos arcabouços jurídicos legais. Nesse sentido, busca-se pela convergência de objetivos; que todos os atores entendam os desafios envolvidos; criação de laços de confiança por meio de um processo de gestão ético, transparente e democrático que conduza à equidade, à racionalidade e à eficiência na tomada de decisões; e a construção de um sentido de identidade de bacia, corresponsabilidade e codependência dos recursos da bacia.

Esses são os fatores para a concretude da boa governança, bem como os princípios do capital social. Ou seja, a criação desses ambientes de confiança e consenso pode ser alcançada pela construção de um pacto entre todos os atores sociais relevantes da bacia, o qual consiste no compromisso de tornar realidade concreta os princípios e os objetivos previstos na legislação. Isso significa criar condições para a governança da água em um ambiente com mecanismos de atuação harmoniosa entre os atores envolvidos.

Esse quadro revela que o processo de participação até então ocorrido propiciou um aprendizado social que gerou o capital social da experiência da gestão compartilhada de recursos hídricos na sub-bacia Cotia-Guarapiranga. Esses assuntos serão a seguir apresentados, e ao final do próximo capítulo será tecida uma reflexão sobre a conexão de todos esses assuntos, a fim de embasar a análise do estudo desta pesquisa; que consiste em analisar o processo participativo do Subcomitê Cotia-Guarapiranga para aprovação da Lei Específica de Proteção da Guarapiranga. 


\section{PARTiCipaÇÃo E APRENDizagem Social na GeStão COMPARTILHADA DE RECURSOS HÍDRICOS}

\subsection{Dimensões da ParticipaÇão Social}

Para abordar as dimensões da participação social será considerado o processo de descentralização, pois até a década de 80 viveu-se com baixa propensão associativista devido à verticalidade na organização política. Para a reversão desse quadro, ocorreram várias reivindicações coletivas por parte dos movimentos sociais para a obtenção de direitos políticos e sociais, a fim de conquistar espaço e participar da gestão pública redefinindo a relação Estadosociedade civil (JACOBI, 2000). Com isso se construiu uma nova institucionalidade baseada na articulação da democracia política com a participação social para o alcance de práticas descentralizadas na gestão do bem público ${ }^{11}$. Nesse contexto, a "participação está estreitamente vinculada ao processo de descentralização, sendo um mecanismo essencial para a democratização do poder público e um espaço vital para a construção da cidadania ativa." (JACOBI, 2000: 71). Segundo Borja (1988 apud JACOBI, 2000), participação é facilitar, tornar mais direto e mais cotidiano o contato entre os cidadãos e as diversas instituições do Estado, e possibilitar que estas levem mais em conta os interesses e opiniões daqueles antes de tomar decisões ou de executá-las.

Quanto à sociedade civil, Bobbio (1987: 35-36) a define como

o lugar onde surgem e se desenvolvem os conflitos econômicos, sociais, ideológicos, religiosos, que as instituições estatais têm o dever de resolver ou através da mediação ou através da repressão. A governabilidade das sociedades complexas pode ser interpretada também nos termos da clássica dicotomia sociedade civil-Estado: uma sociedade torna-se tanto mais ingovernável quanto mais aumentam as demandas da sociedade civil e não aumenta correspondentemente a capacidade das instituições de a elas

\footnotetext{
${ }^{11}$ Na etimologia da palavra, 'democracia' significa "governo do povo", o "governo da maioria", ou seja, um regime de governo que se caracteriza pela liberdade do ato eleitoral, pela divisão dos poderes e pelo controle da autoridade. É um processo onde se aprende a viver juntos respeitando as diferenças. A democracia é uma forma de organização política com reconhecimento do outro (TOURAINE, 1996). E com a democracia surge o Estado moderno, cuja lei máxima é a Constituição escrita e dirigida por um governo que possui soberania reconhecida tanto interna como externamente.
} 
responder, ou melhor, com a capacidade de resposta do Estado alcançando limites talvez não mais superáveis. A ingovernabilidade gera crise de legitimidade.

O desafio é:

Examinar não só os impactos de práticas participativas que apontam para novos espaços de participação sociopolítica, mas também as barreiras a superar para multiplicar iniciativas de gestão que combinem eficazmente complexidade com democracia. Associação entre cidadania, democracia participativa e governabilidade. A análise se concentra no fortalecimento do espaço público, na abertura da gestão pública à participação da sociedade civil no debate e na formulação das políticas sociais, e na sempre complexa e contraditória institucionalização de práticas participativas inovadoras. (JACOBI, 2000: 8).

Inaugura-se, assim, um novo sentido do político, pois se constitui um espaço público de discussão, de luta, de negociação e de diálogo. O espaço democrático é um lugar em que os cidadãos ou os seus representantes apresentam soluções para as diferentes questões da sociedade e juntos buscam criar alternativas coletivas.

Ao olhar as últimas décadas da história, percebe-se que tem ocorrido um interesse pela participação, gerando a multiplicação de associações, movimentos sociais e diversos conselhos. Nessa perspectiva, a participação tem propiciado o crescimento da consciência crítica da população e fortalecido seu poder de reivindicação, o que para os planejadores democráticos significa melhora da qualidade dos serviços, devido à cogestão com a participação da sociedade civil, ou seja, mudanças qualitativas que estimulam a corresponsabilização.

Assim, percebe-se que a participação social é um processo no qual diversos atores sociais têm parte na gestão, uma vez que envolve a sociedade civil em atividades organizadas em grupos para defender interesses comuns e alcançar objetivos econômicos, sociais e políticos; entretanto, há níveis diferentes de participação. O menor grau é o da informação, seguido da consulta. Outro grau é o da elaboração e recomendação, no qual os atores elaboram propostas e recomendam medidas que a administração aceita ou rejeita. Por último, o mais alto grau de participação é a participação ativa. Esta implica em participar da elaboração da agenda política, buscar soluções coletivas para situações-problema, participar da tomada de decisão e da implementação do que foi acordado, sendo corresponsável pela gestão (TOURAINE, 1996). 
Em um processo de participação, quando os membros do grupo participam intensamente, pode-se perceber que o objetivo da ação é relevante para todos. Outro item diz respeito à informação que melhora a qualidade da participação, além de implicar num contínuo processo de criação de conhecimento pelo grupo, tanto sobre si mesmo como sobre seu ambiente, pois sem comunicação e informação não pode existir a participação, é necessário um constante diálogo com base no conhecimento que o grupo tem.

Nesse sentido, Craps (2003) comenta que a participação social é um meio para a aprendizagem social, por permitir que os atores da bacia hidrográfica contribuam com o processo de gestão integrada e sustentável das águas. Porém, a educação para a participação não é simples, na medida em que é uma vivência coletiva e não individual, de modo que somente se pode aprender na praxis grupal; afinal, só se aprende a participar, participando.

Para este trabalho, o recorte que se faz é o desafio da gestão hídrica participativa, a qual, por ser uma realidade que não pode ser gerida por somente um ator, necessita de diversos atores para a concretude da gestão compartilhada das águas. Esses atores sociais formam as arenas de negociação em um processo democrático de negociação, no qual ocorre a aprendizagem social. Logo, percebe-se que a participação é um dos elementos fundamentais para a sequência de negociações entre os múltiplos atores (JACOBI; GRANJA; FRANCO, 2006).

Contudo, esse processo não é simples devido às divergências de interesses. Mas, havendo o comprometimento de todas as partes envolvidas para a efetividade da governança da água, ocorrerá a maturação para a elaboração de estratégias que incorporem os diversos interesses e a sustentabilidade hídrica da bacia hidrográfica.

Com isso, pode-se dizer que a participação social gera capital social, que é compreendido como a capacidade de cada comunidade, de acordo com suas características, de desenvolver um conjunto de relações de confiança e reciprocidade que contribuam para uma ação coletiva, gerando benefícios para todos. Ou seja, as ações praticadas na comunidade, em prol do bem comum, partem da comunhão de forças dos próprios cidadãos. Em suma, a participação social dos cidadãos na gestão de políticas públicas enriquece o capital social, o qual, por sua vez, propicia o desenvolvimento local. A respeito dessa temática o assunto será retomado no item 3.2 deste trabalho.

Com esse panorama, percebe-se que a participação social é um importante instrumento na relação dos cidadãos com o Estado, pois permite que seus direitos sejam reconhecidos e suas demandas incluídas nas decisões políticas. Desse modo, o papel dos atores sociais é reforçar os 
espaços de socialização e descentralização da gestão pública e, com a participação, consolidar o exercício do controle social no planejamento, na gestão, na execução e na avaliação das políticas públicas, contribuindo para o fortalecimento não só dos próprios usuários, mas também dos planejadores e executores das ações (JACOBI, 2000).

Diante desse cenário, o maior desafio é promover o envolvimento da sociedade na gestão compartilhada de recursos hídricos; o que contribui para a promoção da cidadania ativa, do apoio político da sociedade aos programas governamentais, e do interesse e envolvimento de todos os atores sociais na conservação e preservação do meio ambiente. Isso é possível porque a água é um elemento transversal e sua dinâmica está ligada a todos os outros recursos naturais, como processo ecológico essencial que define a evolução de um ecossistema e como condicionante do desenvolvimento econômico e da qualidade da vida humana.

Uma forma de articulação entre a representatividade e a participação pode surgir do fortalecimento da democracia local com a transferência de níveis decisórios para os contextos onde a renovação cultural possa motivar novos arranjos institucionais em diversos níveis. Essas condições são fundamentais para a superação dos padrões clientelistas que marcam as práticas políticas representativas no nível local e regional, como também para o surgimento de projetos de emancipação social.

A esse respeito, Santos e Avritzer (2003) consideram que a democracia participativa e direta pode ser visualizada como um campo social e político onde se reinventa a emancipação social. A partir da reconstrução do espaço de interlocução entre o Estado e a sociedade civil, novos saberes tornam-se possíveis mediante a redefinição de identidades e vínculos, surgem, assim, novas temáticas até então ignoradas pelo sistema político.

Essa proposta política é especialmente importante quando são abordados os processos de gestão ambiental, nos quais há a necessidade de mudança de valores e de construção de uma gramática social e cultural capaz de gerar novas estratégias consensuais. A sustentabilidade das soluções previstas depende fundamentalmente da construção de um saber ambiental culturalmente enraizado no empoderamento dos grupos sociais envolvidos na vida local (LEFF, 2001).

Administrar os conflitos ambientais, oriundos da gestão democrática, pressupõe um processo de disponibilização de informação a várias camadas da população, sensibilização e mobilização para que ocorra a participação crítica e o exercício da cidadania na gestão da água (JACOBI, 2004) - bem de domínio público, dotado de valor econômico (BRASIL, 1997). Sua 
disponibilidade interfere diretamente no desenvolvimento social e econômico dos países, o que fez surgir em escala mundial a preocupação ambiental, devido aos danos ambientais decorrentes de um processo de industrialização com forte impacto nos recursos naturais.

Dessa maneira, as consequências do uso não sustentável dos recursos naturais são refletidas em todas as atividades humanas e os reflexos insustentáveis, das ações predatórias que promovem a sua degradação, ocorrem nas bacias hidrográficas - unidade de gestão de recursos hídricos.

Cabe ressaltar que a gestão compartilhada de recursos hídricos somente se efetiva quando, de fato, existe apoio ativo da comunidade local. No entanto, para que isso ocorra é necessária uma participação reconhecida e estimulada não só por ser um direito básico da sociedade, mas porque é fundamental no processo de gestão compartilhada. Assim sendo, a democracia, a cidadania e a proteção do meio ambiente caminham juntas, pois

não basta o envolvimento das organizações governamentais e internacionais nesses esforços. É fundamental que as questões globais adquiram importância no nível local, onde é causado o dano ao meio ambiente, e devem ser tratadas e compreendidas pela população como um todo. (FURRIELA, 2002: 24).

Com esse cenário, pressupõe-se que, para a governança da água, se coloca a importância da contribuição dos diversos atores envolvidos, de forma a fortalecer uma visão ética, participativa, integrada e comunicativa (SOLANES; JOURAVLEV, 2006; ROGERS; HALL, 2003) visando formular alternativas de gerenciamento que minimizem os conflitos de interesses de grupos diversos (JACOBI, 2006); pois, mesmo tendo garantida a representação da sociedade civil, esta, por sua vez, também apresenta interesses conflituosos ou até antagônicos.

\subsection{O Papel do Capital Social}

Por que utilizar a teoria de capital social na reflexão sobre a gestão compartilhada de recursos hídricos? Porque a teoria de capital social é 
um instrumento conceitual e prático para a consolidação de políticas públicas, para o desenvolvimento sustentado e para a revitalização da sociedade civil e a democracia. Ela é ferramenta útil para auxiliar a comunidade e governo a resolverem problemas socialmente relevantes. (ARAUJO, 2003: 7-8).

Incorporar esse referencial na análise do processo de elaboração da Lei Específica da Guarapiranga - objeto desta pesquisa para a reflexão da gestão compartilhada - é prudente, pois foca no fortalecimento das relações sociais, na formação e manutenção das organizações sociais, tendo como fatores explicativos as normas, a confiança, a cooperação e as redes sociais realizadas por ocasião da elaboração da referida Lei.

Mas de onde veio e como surgiu a adoção dessa teoria?

Essa forma avaliativa ganhou notoriedade com a pesquisa multidisciplinar realizada por Putnam, iniciada em 1970 e que perdurou por 20 anos, que teve por foco a implantação da descentralização administrativa na Itália. No contexto mundial a discussão estava relacionada aos governos centralizados e à necessidade de valorizar o poder local, fortalecer as comunidades e promover o desenvolvimento sustentado, mas sem deixar de pensar no global para o agir local.

A popularização do termo 'capital social' surgiu ao longo da última década do século XX e sua empregabilidade na análise da gestão compartilhada de recursos hídricos é pertinente, na medida em que busca compreender como ocorre a coordenação e cooperação entre os atores sociais da bacia hidrográfica, quando laços de confiança se fazem presentes. O capital social amplia a capacidade de ação coletiva, por facilitar a cooperação mútua necessária para a otimização dos resultados, a fim de garantir a efetiva governança da água.

Para Fernandes (2002), a construção dos laços de confiança e fidelidade favorece a cooperação social, que propicia o aumento do desempenho e da responsabilidade dos governos e das instituições democráticas. Em outras palavras, é a aplicação do capital social no desempenho institucional e na elaboração das políticas públicas, realizada pela sinergia entre Estado e sociedade civil, que mobiliza os indivíduos para a ação coletiva, ampliando a democracia e tornando mais eficiente a realização das políticas públicas. "O capital social de uma associação, grupo ou comunidade amplia sua capacidade de ação coletiva e facilita a cooperação mútua necessária para a otimização do uso de recursos materiais e humanos disponíveis.” (FERNANDES, 2002: 379). 
De acordo com Putnam (2006), o capital social está relacionado com cidadania, civismo e democracia, e sua operacionalidade se dá por três variáveis: confiança interpessoal, confiança institucional e participação cívica, mostrando que as redes de engajamento cívico criam os fundamentos para uma governança democrática. Dito de outra forma, o capital social é fruto da confiança, da cooperação, das regras de reciprocidade e da participação cívica, fatores estes que tiveram (têm) sua parcela de contribuição na gestão compartilhada de recursos hídricos.

Para exemplificar que o processo de negociação pode ser melhor quando todos cooperam para o bem comum, tem-se a parábola do filósofo escocês David Hume, o qual demonstra que, havendo cooperação e confiança na negociação, ambas as partes saem ganhando. Veja aqui a situação dos agricultores:

Teu milho está maduro hoje; o meu estará amanhã. É vantajoso para nós dois que eu te ajude a colhê-lo hoje e que tu me ajudes amanhã. Não tenho amizade por ti e sei que também não tens por mim. Portanto, não farei nenhum esforço em teu favor; e sei que se te ajudar esperando alguma retribuição, me decepcionarei, pois não poderei contar com a tua gratidão. Então, deixo de ajudar-te; e tu me pagas na mesma moeda. As estações mudam; e nós dois perdemos nossas colheitas por falta de confiança mútua. (HUME, 1740 apud PUTNAM, 2006: 173).

Essa parábola traduz exatamente como são estabelecidas as relações quando não há empatia pela outra parte, mas sim interesses em comum. Essa situação pode ser traduzida para a realidade dos CBHs, na qual os diferentes atores sociais estão reunidos, mas não necessariamente unidos para a gestão do bem comum, a água.

Nesse sentido, identifica-se na arena de negociação da gestão compartilhada das águas a diversidade de interesses; contudo, se não houver pacto de confiança, todas as partes do jogo de negociação perderão. O que significa que não haverá água em quantidade e qualidade demandada por todos, tanto para os atores diretamente envolvidos na negociação, membros dos CBHs, quanto aos atores indiretos, que são a população de modo geral atendida pela água de seus respectivos mananciais.

Com isso, percebe-se que o capital social diz respeito às características da organização social, como confiança, cooperação e normas, que contribuem para aumentar a eficiência da sociedade, facilitando as ações coordenadas; pois cooperar gera compromisso. Do contrário, quando os atores envolvidos são incapazes de assumir compromissos entre si, eles têm que 
renunciar a oportunidades de proveito mútuo, porque o capital social não é propriedade de uma das partes beneficiadas, mas sim de todo o coletivo.

Nesse contexto, as regras ${ }^{12}$ e as instituições são aspectos importantes do capital social, pois contribuem para a ordem no desenvolvimento das atividades otimizando os resultados, desde que não sejam impostas, mas sim criadas em comum acordo entre os atores sociais; isso porque o ambiente democrático favorece o capital social em qualquer sociedade, por desempenhar um papel de indução de mudanças sociais e promoção do desenvolvimento. Nesse sentido, criam-se "sistemas de governança onde os indivíduos têm oportunidades de se organizar em múltiplas escalas" (CASTELLANO, 2007: 35), conduzindo a um sistema de sinergia Estado-sociedade.

Para Fernandes (2002: 390) "o estabelecimento de uma relação de sinergia entre Estado e sociedade pode produzir capital social", sendo que essa sinergia pode ser complementar ou de inserção. Sinergia como complementaridade significa a parceria público-privado, enquanto a sinergia como inserção "baseia-se na idéia de laços que conectam cidadãos e funcionários púbicos e cruzam a divisa público-privado." Com isso, complementaridade e inserção precisam estar combinadas para que haja a integração dos cidadãos, setor privado e Poder Público. Mas, conforme ressalta Evans (1997 apud FERNANDES, 2002),

as tentativas de sinergia podem falhar ou ser bem-sucedidas e um dos aspectos que contribuem para o sucesso ou fracasso dos programas partilhados é o regime político. Um contexto político de igualdade e competitividade, não autocrático, representa um requisito mínimo que facilita a sinergia e, portanto, a formação de capital social. Mas um aspecto importante [...] na relação sinérgica entre Estado e sociedade civil, tornando possível a produção de capital social, é a atitude do setor público em incorporar a construção de civismo comunitário como elemento do seu trabalho. (FERNANDES, 2002: 391-392).

É importante destacar que o capital social pode ser o resultado da atuação em rede de associações horizontais ou por alianças políticas feitas por grupos sociais relevantes para a elaboração das políticas. No primeiro caso, nota-se uma solidez na base para a implementação das políticas públicas, enquanto que, no segundo, depender de grupo político que está no poder não garante a continuidade e o desempenho da política desenhada. Essa situação ocorre porque

\footnotetext{
${ }^{12}$ Regras são as "prescrições que especificam quais ações ou resultados são requeridos, proibidos ou permitidos, e as sanções autorizadas caso as regras não sejam seguidas." (OSTROM et al., 1994: 38 apud CASTELLANO, 2007: 33).
} 
o capital social pode ser construído ou destruído, conforme afirma Putnam (2000: 413 apud FERNANDES, 2002: 394), pois "o governo pode ser o problema ou a solução". Apesar dos problemas resultantes da relação Estado e sociedade civil, nenhum deles pode resolver os problemas sozinho, já que ambos são importantes.

Essa prática é possível pelo fato do capital social ter a capacidade de cooperar e confiar para a produção do bem público, no formato de redes de relações, cujos benefícios são comuns para toda a sociedade, pois a interação ocorre de forma não hierarquizada. A prática dessa cultura favorece a prosperidade de toda a sociedade, uma vez que, de acordo com Hirshman (apud ARAUJO, 2003), quanto mais se pratica a cooperação e a confiança, mais se produz cooperação e confiança, logo mais prosperidade. Ou seja, a cooperação e a confiança propiciam prosperidade pela via da democracia.

Dessa forma, pode-se afirmar que a confiança, a cooperação e as regras são componentes básicos do capital social, afinal cada cidadão tem consciência de seu papel e de seus deveres, numa espécie de contrato moral, com o compromisso político da gestão compartilhada. Por outro lado, a falta de confiança gera instituições frágeis inviabilizando a democracia e o desenvolvimento, o que repercute nas políticas públicas. Assim sendo, é preciso pensar o impacto do capital social sobre a política e suas instituições, pois as relações até aqui expostas demonstram a sinergia, a energia que vem da confluência positiva dos segmentos, público, privado e sociedade civil.

Este é o desafio da gestão compartilhada: fazer uso do capital social gerado no processo de aprendizagem social, pois toda experiência gera seu aprendizado, o que pode ser reestruturado após avaliação a fim de melhorar o sistema de participação social para a governança da água.

Isso demonstra a cooperação para o bem-estar individual e o zelo pelo governo democrático e transparente. Dito em outras palavras, o capital social é a relação entre governo e cidadão, participação política, transparência e boa governança. Logo, "ditaduras são regimes corrosivos da confiança, base do capital social, e depredadoras da sociedade civil.” (ARAUJO, 2003: 53).

E como isso ocorre? "Para a estabilidade política, para a boa governança e mesmo para o desenvolvimento econômico, o capital social pode ser mais importante até do que o capital físico ou humano.” (PUTNAM, 2006: 192). Essa dinâmica se dá pela atuação em redes que são instrumentos eficazes de emprego do capital social, gerado em um território a partir das relações 
sociais grupais que o transforma em instrumentos de otimização das iniciativas coletivas, rumo à formulação e implementação da política de água de forma compartilhada.

A teoria do capital social é utilizada também para a avaliação de projetos, como tem feito o Banco Mundial a partir dos anos 90; o qual parte do pressuposto de que o capital social está relacionado à "capacidade de uma sociedade de estabelecer laços de confiança interpessoal e redes de cooperação com vistas à produção de bens coletivos, ou seja, refere-se às instituições, relações e normais sociais que dão qualidade às relações interpessoais em uma dada sociedade." (ARAUJO, 2003: 10). Desse modo, o capital social é o link que mantém as instituições em contato entre si e vinculadas ao cidadão para a produção do bem comum; todavia, só é possível que isso ocorra se houver cooperação e confiança.

\subsection{Aprendizagem Social na GeStão Compartilhada de ReCURSOS HíDRICOS}

Os problemas atuais relacionados à sustentabilidade da água têm demandado maior atenção para a questão da participação por contribuir com a melhora da governança da água, com o objetivo de alcançar soluções integradas e responder à complexidade da gestão hídrica dos dias atuais. Por serem os problemas complexos, faz-se necessária uma multiplicidade de atores sociais para a resolução dos mesmos. Nessa perspectiva, a aprendizagem social traz a contribuição dos diversos atores envolvidos na bacia hidrográfica que participam de uma mesma arena de negociação, que são os Comitês de Bacias Hidrográficas (CBHs). Nesses espaços, todos os atores com interesses diversificados trabalham de forma coletiva e tomam as decisões de forma compartilhada, além de serem corresponsáveis na implementação das ações acordadas.

Mas de onde vem esse conceito e por que é utilizado para a análise da gestão de recursos hídricos? O conceito de aprendizagem social vem de diferentes disciplinas das ciências sociais e tem por principal foco de estudo a interação entre os indivíduos e grupos nas diferentes organizações, processo básico para a aprendizagem (MOSTERT, 2003).

Dentre vários estudiosos de diferentes áreas sociais, Albert Bandura, psicólogo preocupado com os efeitos dos meios de comunicação de massa, afirma que o indivíduo 
aprende, em primeiro lugar, por apenas observar os outros (BANDURA, 1977 apud MOSTERT, 2003), por isso a utilização desse referencial: aprendizagem social na gestão compartilhada de recursos hídricos. E por quê? Porque são 18 anos de Política Estadual de Recursos Hídricos, 15 anos de Comitê da Bacia Hidrográfica do Alto Tietê e 12 anos de Subcomitê da Bacia Hidrográfica Cotia-Guarapiranga. Desse período é possível obter lições para o aperfeiçoamento da gestão participativa da água, a qual demanda articulação do uso sustentável dos recursos hídricos com o uso e ocupação do solo, pois interfere diretamente na disponibilidade hídrica da região, já que os sistemas naturais e sociais não podem ser tratados de maneira desconexa.

Cabe ressaltar que, dentro dessa cronologia, este trabalho voltará suas lentes para a experiência do SCBH-CG no processo de elaboração da Lei Específica n. ${ }^{\circ}$ 12.233/06 ${ }^{13}$, no período de 1999 a 2006, no que se refere à negociação entre os diversos atores na perspectiva da gestão descentralizada e compartilhada de recursos hídricos, conforme Lei n. ${ }^{\circ}$ 9.433/97 (BRASIL, 1997). Em outras palavras, como foi possível diferentes grupos, com interesses diversificados, tomarem decisões conjuntas, visando alcançar soluções sustentáveis (PAHLWOSTL, 2002; SOCIAL LEARNING GROUP, 2001 apud MOSTERT, 2003)?

Para uma possível resposta, é preciso considerar o processo histórico da gestão da água, pois em seu formato tradicional era realizada por especialistas da área, mas, em virtude da complexidade e incerteza de sua sustentabilidade, surge uma nova forma de governança substituindo o sistema hierárquico tradicional, orientado pelo controle, o qual passa a ser participativo e baseado no aprendizado social entre os múltiplos atores envolvidos (CRAPS, 2003). Para a sustentabilidade acima referida, é preciso que haja a aprendizagem social, uma vez que esta é baseada em diálogos entre os decisores políticos, cientistas, as partes interessadas e o público em geral (CRAPS, 2003).

Com o novo paradigma da gestão hídrica, passa-se a contar com a participação de diversos atores sociais da bacia hidrográfica para a gestão das águas de forma participativa, descentralizada e integrada. Nesse novo formato, as práticas de gestão se dão num processo de construção coletiva, tendo diálogo e participação, o que resulta em práticas colaborativas. Tais práticas permeiam essa nova cultura de espaços de convivência, debates e desafios para a construção das negociações com diálogos horizontalizados concretizando o exercício da democracia participativa.

\footnotetext{
${ }^{13}$ São Paulo (2006).
} 
Tal concretização é possível em virtude da somatória das diferentes experiências dos atores sociais para a construção de projetos de intervenção de forma coletiva. Assim, pode-se dizer que a aprendizagem social propicia ao conjunto de atores a construção coletiva de acordos para a governança da água nas bacias hidrográficas. Esse é um processo reflexivo, o que viabiliza uma reavaliação da prática da gestão compartilhada nas bacias hidrográficas. Porém, esse é um processo longo e lento da aprendizagem social, que é mantido pelo contato entre os representantes de diversos grupos sociais. Esses atores aprendem a ver o valor das contribuições de cada um, a fim de desenvolver uma visão sistêmica dos problemas e desafios.

Assim sendo, Craps (2003) comenta que a aprendizagem social baseia-se em parcerias entre governo, especialistas, usuários e outras partes interessadas em alternativas para a gestão da água. Dessa forma, espera-se que a aprendizagem social possa contribuir com o processo de busca das soluções para os problemas de sustentabilidade, governança e conflitos em nível mundial, pois a aprendizagem social tem seus impactos sobre o sistema de governança da água no que se refere à sustentabilidade ecológica e social das bacias hidrográficas. Isso é possível porque se trata de um processo onde os atores envolvidos na gestão das bacias hidrográficas buscam no interior do grupo as práticas para a solução das situações-problema.

Nesse quadro, a situação problema da gestão compartilhada é analisada por todos os envolvidos, e as estratégias desenhadas visam incorporar a corresponsabilização de ambas as partes. Assim, percebe-se que a negociação gera algum aprendizado, pois as interações de uns com os outros estabelecem relações sociais, dentro de um determinado contexto. O desafio está em alcançar acordos que satisfaçam os interesses prioritários de cada um e contemplem a sustentabilidade hídrica e ambiental, o que levou no SCBH-CG um período de 8 anos para aprovação da Lei Específica n. ${ }^{\circ}$ 12.233/06.

Para o Projeto HarmoniCOP (RIDDER; MOSTERT; WOLTERS, 2005), a aprendizagem social é caracterizada por uma forma emblemática do "Aprender Juntos para Compartilhar". Na gestão compartilhada das águas, isso significa que o plano de bacia será um processo de construção coletiva, realizado pelos diversos atores sociais presentes na bacia de forma negociada, a fim de alcançar a melhoria da gestão das águas naquela região hidrográfica; o que é possível devido à principal característica do aprendizado social: a disposição para o trabalho cooperativo e a participação de todos os atores envolvidos em diálogo constante.

Esse é o processo de aprendizagem social, quando todos os cidadãos são envolvidos para a realização de uma gestão colaborativa, permeada pelo diálogo e práticas interativas para o processo de tomada de decisão. Em outras palavras, aprendizagem social envolve ativamente 
os diferentes grupos na sociedade em um processo de entendimento dos problemas, conflitos e dilemas sociais, e juntos criam estratégias para melhorar a situação. Desse modo, a aprendizagem social envolve a participação da comunidade em uma aprendizagem em grupo, o que favorece a governança da água. Afinal, é no contexto do processo de gestão compartilhada que a aprendizagem social é identificada nas interações entre os indivíduos e nos grupos levando às práticas conjuntas (CRAPS, 2003).

Outro conceito de aprendizagem social (PAHL-WOSTL; HARE, 2004: 2; PAHLWOSTL et al., 2007: 9) considera que a

aprendizagem em bacias hidrográficas é necessário para desenvolver e sustentar a capacidade de diferentes autoridades, peritos, grupos de interesse, bem como o público para gerir as suas bacias hidrográficas de maneira sustentável e equilibrar múltiplos interesses concorrentes e para o benefício do sistema sócio-ecológico como um todo.

Nessa perspectiva, a aprendizagem social se insere na compreensão de governança da água devido à sua capacidade de diálogo, reflexão e ação entre os atores sociais envolvidos na gestão, pois ocorre a socialização do conhecimento entre os diferentes atores sociais; com isso a aprendizagem social vai se consolidando. Contudo, para a sua operacionalização faz-se necessária a contribuição de um facilitador, de preferência externo devido à sua imparcialidade quanto aos resultados a serem alcançados, para facilitar a negociação e, assim, alcançar ganhos mútuos, construção dos consensos e celebração dos acordos que contemplem os interesses das partes envolvidas.

Essa não é uma tarefa simples, em decorrência das divergências de interesses, mas havendo o comprometimento de ambas as partes ocorrerá a maturação para o direcionamento das ações que atenderão aos diversos interesses envolvidos. Pode-se assim concluir que aprendizagem social é aprender junto para intervir juntos, tendo todos a corresponsabilidade para criar cenários de sustentabilidade para a bacia hidrográfica em questão (RIDDER; MOSTERT; WOLTERS, 2005), pois os CBHs são campos de articulação inspirados no modelo de democracia participativa que, em síntese, propõe a partilha de poder e estabelece que os seus membros terão por objetivo principal buscar o consenso para a gestão compartilhada.

A ampla participação social é uma condição para a aprendizagem social, cujos resultados derivam de um processo que possibilita uma boa governança e a sustentável gestão 
de bacias hidrográficas. Nesse contexto, a aprendizagem social requer que os especialistas e os leigos reconheçam suas potencialidades e limitações para que as decisões levem em conta as perspectivas de todos os interessados (CRAPS, 2003).

Assim, a aprendizagem social pode ser vista como um meio para se chegar a decisões que podem ser mais bem executadas e tecnicamente corretas e socialmente justas. Cabe ressaltar que esse processo é lento e complexo, e funciona melhor quando todas as partes envolvidas podem desenvolver-se conjuntamente para a definição da direção a ser tomada.

Resumidamente, pode-se dizer, segundo Pahl-Wostl e Hare (2004), que os ingredienteschave para a aprendizagem social são:
a) ter consciência que os objetivos e perspectivas são diferentes entre cada membro do grupo;
b) identificar o problema em comum;
c) compreender a interdependência dos atores;
d) compreender a complexidade do sistema de gestão;
e) aprender a trabalhar em conjunto;
f) criar confiança;
g) criar relações formais e informais. 


\section{GovernanÇa da Água no SUbCOMItê dA BACIA Hidrográfica Cotia-GuARAPIRANGa}

\subsection{A BaCia Hidrográfica do Alto Tietê}

\subsubsection{CARACTERÍSTICAS GERAIS}

A bacia hidrográfica do Alto Tietê compreende a área de $5.900 \mathrm{~km}^{2}$, com extensa superfície urbanizada e formada por 35 municípios. A delimitação física da bacia do Alto Tietê é quase a totalidade da Região Metropolitana de São Paulo ${ }^{14}$ (RMSP) (Figura 2), que é formada por 39 municípios ocupando uma área de $8.050 \mathrm{~km}^{2}$, sendo $1.500 \mathrm{~km}^{2}$ de área urbana. A população atual é de, aproximadamente, 20 milhões de habitantes, o que demonstra o desafio e a urgência de processos de articulação e integração entre a gestão urbana e a gestão das águas, ou seja, integrar a gestão de recursos hídricos com a gestão de uso e ocupação do solo (PORTO, 2003).

\footnotetext{
${ }^{14}$ Municípios da RMSP: Arujá, Barueri, Biritiba Mirim, Caieiras, Cajamar, Carapicuíba, Cotia, Diadema, Embu, Embu-Guaçu, Ferraz de Vasconcelos, Francisco Morato, Franco da Rocha, Guarulhos, Itapecerica da Serra, Itapevi, Itaquaquecetuba, Jandira, Mairiporã, Mauá, Mogi das Cruzes, Osasco, Pirapora do Bom Jesus, Poá, Ribeirão Pires, Rio Grande da Serra, Salesópolis, Santana de Parnaíba, Santo André, São Bernardo do Campo, São Caetano do Sul, São Paulo, Suzano, Taboão da Serra, Juquitiba e São Lourenço da Serra.
} 


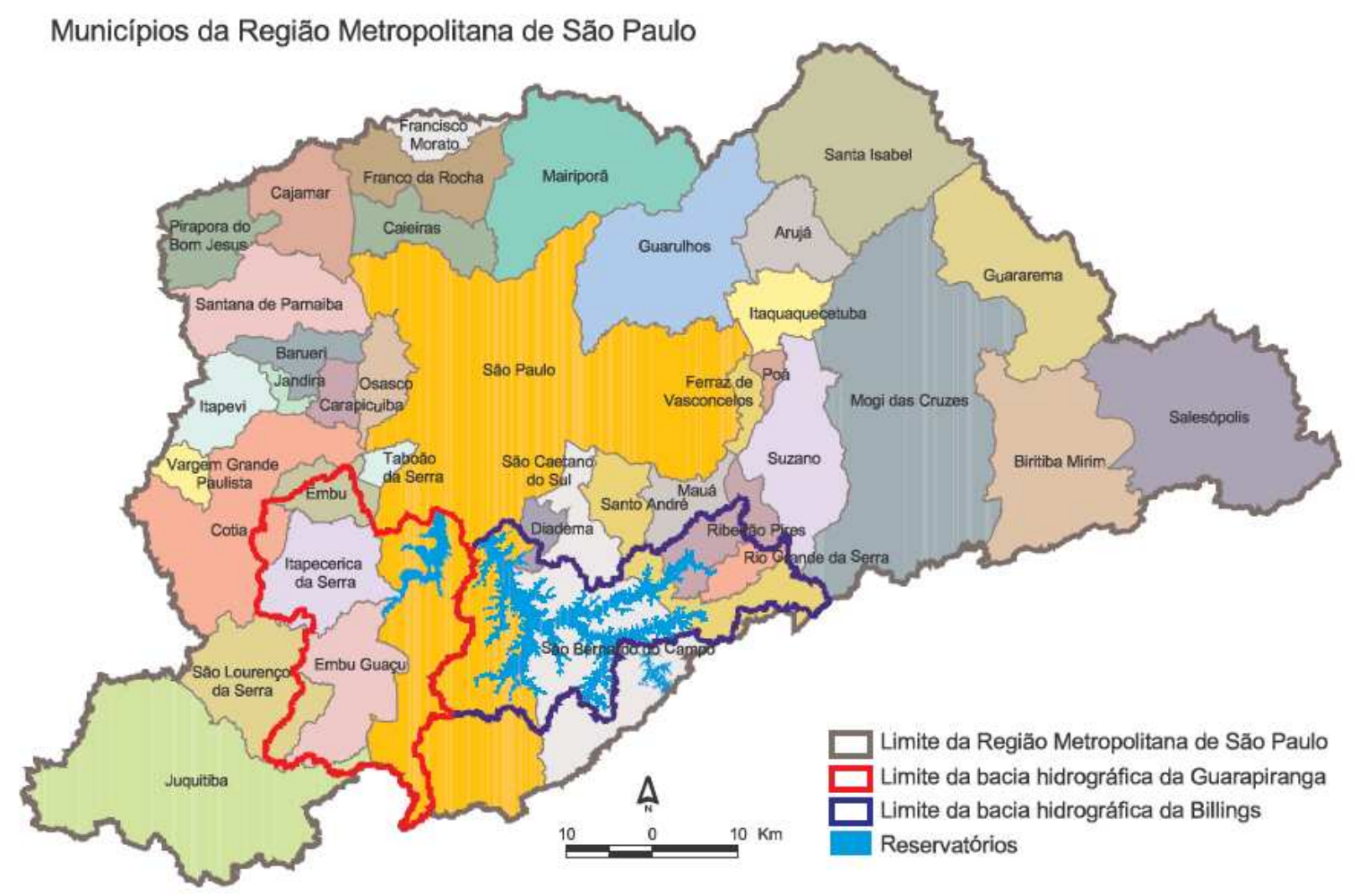

FigURA 2 - Mapa dos municípios da região metropolitana de São Paulo. FONTE: ISA (2008a).

Os principais contribuintes do rio Tietê nas suas cabeceiras são os rios: Claro, Paraitinga, Jundiaí, Biritiba-Mirim e Taiaçupeba, que, juntamente com o próprio rio Tietê, compõem o quadro que forma um dos mais importantes mananciais de abastecimento da região, destacando-se os reservatórios Ponte Nova, Jundiaí e Taiaçupeba, projetados e implantados para o abastecimento público como finalidade principal, e, secundariamente, para o controle de enchentes.

A Região Metropolitana de São Paulo é abastecida, em sua maior parte, por três grandes sistemas produtores: Sistema Cantareira, Sistema Guarapiranga/Billings e Sistema Alto Tietê, e mesmo assim possui baixa disponibilidade hídrica por habitante, comparável às áreas mais secas do Nordeste brasileiro. Isso ocorre por estar localizada numa região de cabeceira e por ser o maior aglomerado urbano do país, com alta demanda hídrica (SILVA; PORTO, 2003). 


\subsubsection{A PROBLEMÁTICA DA BACIA}

A RMSP é a mais importante área produtora de bens industriais do país, tanto em termos de geração de emprego como de renda. Cresce também o setor de serviços, que nos últimos anos passou a ser o setor de maior desenvolvimento e de geração de novos empregos da região (SILVA; PORTO, 2003).

A RMSP em 1975 tinha 9,6 milhões de habitantes, passando para 18,3 milhões em 2005 e a projeção para 2015 é de 20,5 milhões de habitantes. A área urbanizada ocupa aproximadamente $37 \%$ da área da bacia, e a expulsão da população de baixa renda para as zonas periféricas das cidades agrava a degradação ambiental pela expansão desordenada e pela falta de infraestrutura adequada, gerando os consequentes problemas de ocupação de áreas de proteção aos mananciais e das várzeas, além da necessidade de expansão dos sistemas de abastecimento de água e coleta de esgotos sanitários e de coleta de lixo (FUSP, 2002 apud CUNHA, 2004).

Sendo a água de um manancial o resultado da drenagem da bacia correspondente, sua qualidade será a resultante das ações que se realizarem no solo dessa bacia, consequentemente, a constante preservação dessa qualidade somente será possível através do disciplinamento do uso do solo, tendo em vista os usos que serão feitos da água (BRANCO; ROCHA, 1977). No caso da RMSP a situação de degradação dos recursos hídricos é alarmante, embora a área ocupada seja de apenas 1/3, o que numericamente seria irrisório; mas esse 1/3 é o suficiente para gerar essa degradação dos recursos naturais, devido à expansão urbana desordenada, pela falta de infraestrutura adequada e pelos problemas de ocupação de áreas de proteção aos mananciais, bem como pela poluição e contaminação dos mananciais.

Para tentar reverter o quadro degradante da bacia e no intuito de implementar a legislação hídrica, foi criado o Comitê da Bacia Hidrográfica do Alto Tietê (CBH-AT), como será apresentado a seguir. 


\subsubsection{COMITÊ DA BACIA HIDROGRÁFICA do Alto TIETÊ}

O Comitê da Bacia Hidrográfica do Alto Tietê (CBH-AT) foi criado em 09 de novembro de 1994 e corresponde, praticamente, à Região Metropolitana de São Paulo. Sua criação, conforme prevista na Lei Estadual n. ${ }^{0}$ 7.663/91, foi motivada pelo agravamento das condições ambientais da bacia, devido ao comprometimento da qualidade e quantidade da água que geram diversos conflitos pelo seu uso, necessitando de um novo formato de gestão hídrica, a fim de promover o gerenciamento descentralizado, participativo e integrado dos recursos hídricos.

O CBH-AT, em sua composição, atende aos princípios da gestão tripartite, formado pelos três segmentos: Estado, municípios e sociedade civil. Conforme o artigo $9^{\circ}$ de seu estatuto, o Estado será representado por 18 titulares e respectivos suplentes, dos seguintes órgãos (COMITE-AT, 2008):

a) 1 (um) representante da Coordenadoria de Recursos Hídricos da Secretaria Estadual de Energia, Recursos Hídricos e Saneamento;

b) 1 (um) representante da Coordenadoria de Energia da Secretaria de Estadual de Energia, Recursos Hídricos e Saneamento;

c) 1 (um) representante do Departamento de Águas e Energia Elétrica DAEE;

d) 1 (um) representante da Companhia de Saneamento Básico do Estado de São Paulo - SABESP;

e) 1 (um) representante da Secretaria Estadual de Meio Ambiente;

f) 1 (um) representante da Fundação Florestal;

g) 1 (um) representante da Companhia de Tecnologia de Saneamento Ambiental - CETESB;

h) 1 (um) representante da Empresa Metropolitana de Águas e Energia EMAE;

i) 1 (um) representante da Secretaria Estadual de Economia e Planejamento;

j) 1 (um) representante da EMPLASA - Empresa Metropolitana de Planejamento da Grande São Paulo S/A;

k) 1 (um) representante da Secretaria Estadual de Agricultura e Abastecimento;

1) 1 (um) representante da Secretaria Estadual da Saúde, vinculado à área de vigilância sanitária;

m) 1 (um) representante da Secretaria Estadual de Ciência, Tecnologia e Desenvolvimento Econômico;

n) 1 (um) representante do Instituto de Pesquisas Tecnológicas - IPT;

o) 1 (um representante da Secretaria Estadual dos Transportes; 
p) 1 (um) representante da Secretaria Estadual da Habitação;

q) 1 (um) representante da Secretaria Estadual de Educação;

r) 1 (um) representante da CEDEC - Coordenadoria Estadual de Defesa Civil.

Ao que cabe aos municípios, estes estão representados por 18 prefeitos ou representantes, por eles indicados, e seus respectivos suplentes, compreendendo todos os municípios que formam os 5 subcomitês do Alto Tietê (COMITE-AT, 2008).

Em 1997, devido à complexidade e problemas tão diversos que caracterizam a região, foram criados cinco subcomitês: Tietê-Cabeceiras, Cotia-Guarapiranga, Juqueri-Cantareira, Billings-Tamanduateí e Pinheiros-Pirapora. No entanto, neste trabalho, o subcomitê a ser estudo será o Cotia-Guarapiranga, por ser o primeiro a elaborar a Lei Específica de Proteção aos Mananciais no Estado de São Paulo.

Quanto à sociedade civil, esta está representada por 18 representantes, também titulares e suplentes, das seguintes categorias (COMITE-AT, 2008):

a) 2 (dois) representantes de associações ligadas ao consumo do recurso hídrico para uso doméstico final, com interesse no abastecimento público, saneamento e saúde pública;

b) 2 (dois) representantes de associações ligadas ao consumo do recurso hídrico para atividades industriais;

c) 2 (dois) representantes de associações ligadas ao consumo do recurso hídrico para atividades agrícolas;

d) 2 (dois) representantes de associações ligadas ao consumo do recurso hídrico para atividades de comércio, lazer e serviços;

e) 3 (três) representantes de associações de defesa do meio ambiente;

f) 3 (três) representantes de associações técnicas especializadas em recursos hídricos;

g) 1 (um) representante de organizações sindicais de trabalhadores com atuação em recursos hídricos, meio ambiente e saneamento;

h) 1 (um) representante de associações científicas (universidades, institutos de ensino superior e entidades de pesquisa e desenvolvimento tecnológico);

i) 1 (um) representante titular adicional para a categoria com o $1^{\circ}$ maior número de inscritos devidamente habilitados;

j) 1 (um) representante titular adicional para a categoria com o $2^{\circ}$ maior número de inscritos devidamente habilitados. 
Ao que se refere à composição do segmento sociedade civil, conforme deliberação CBH-AT n. ${ }^{\circ}$ 09/04, de 14 de dezembro de 2004, esta compreende usuários de recursos hídricos e entidades civis, assim especificados (COMITE-AT, 2008):

Artigo $1^{\circ}$ : São considerados usuários de recursos hídricos toda pessoa física ou jurídica que desenvolva atividades na área da Bacia Hidrográfica do Alto Tietê - UGRHI 6, nos seguintes setores:

I - abastecimento urbano e lançamento de efluentes urbanos, compreendendo as entidades públicas municipais e privadas, responsáveis pelos sistemas de abastecimento de água potável ou pelo esgotamento sanitário, com captação de água ou lançamento de efluentes, diretamente nos corpos d'água superficiais e subterrâneos, bem como as entidades de defesa do consumidor na representação coletiva do usuário doméstico;

II - indústria, comércio, prestação de serviços e mineração, compreendendo os usuários de recursos hídricos com atividades comerciais, de prestação de serviços, industriais e de exploração mineral, com captação de água ou lançamento de efluentes, diretamente nos corpos d'água superficiais e subterrâneos;

III - irrigação e uso agropecuário, compreendendo os produtores rurais que desenvolvam agricultura irrigada, aquicultura e criadores de animais em geral, com captação de água ou lançamento de efluentes, diretamente nos corpos d'água superficiais e subterrâneos;

$\S 1^{\circ}$ a participação dos usuários de recursos hídricos, no Plenário do CBH-AT, dar-se-á por meio de entidades associativas, por eles eleitas.

$\S 2^{\circ}$ As entidades associativas (sede, filial, sucursal ou representação) deverão estar sediadas na área de atuação do Comitê do Alto Tietê.

$\S 3^{\circ}$ As entidades associativas poderão indicar como seu representante qualquer usuário associado.

Artigo $2^{\text {o: }}$ São consideradas organizações da sociedade civil, não enquadradas como usuários de recursos hídricos, toda pessoa jurídica que desenvolva atividades na bacia do Alto Tietê, dentro dos seguintes setores:

I - universidades, institutos de ensino superior e entidades de pesquisa e desenvolvimento tecnológico, com interesse na área de recursos hídricos, que atuem no desenvolvimento de projetos, estudos, pesquisas, ou outras atividades diretamente relacionadas aos recursos hídricos ou às questões ambientais;

II - sindicatos de trabalhadores, associações técnicas não-governamentais e associações comunitárias, que atuem no desenvolvimento de projetos, estudos, pesquisas, ou outras atividades diretamente relacionadas às questões ambientais ou específicas de recursos hídricos, na área de atuação do Comitê AT;

III - entidades ambientalistas, e entidades privadas sem fins lucrativos na defesa do meio ambiente e com atuação na área de recursos hídricos. 
Parágrafo único - As organizações da sociedade civil, relacionadas nos itens "I" a "III" do caput deste artigo deverão possuir sede, filial, sucursal ou representação com sede na área de atuação do Comitê do Alto Tietê.

Artigo $3^{\circ}$ : O processo de escolha dos membros do CBH-AT, do segmento sociedade civil (usuários de recursos hídricos e organizações da sociedade civil), ocorrerá através de Plenárias, a serem realizadas durante Assembléia Geral da Sociedade Civil.

A presidência do comitê é exercida por representante municipal, a vice-presidência por representante da sociedade civil e a secretária executiva por representante do Estado. Embora esses cargos estejam previstos no estatuto, a composição é definida por costume, de maneira informal, pois não consta no documento.

\subsection{A Sub-BaCia Hidrográfica Cotia-Guarapiranga}

\subsubsection{CARACTERÍSTICAS GERAIS}

A sub-bacia hidrográfica Guarapiranga está localizada na porção sudoeste da Região Metropolitana de São Paulo e ocupa uma área de $639 \mathrm{~km}^{2}$ formada por sete municípios, sendo dois totalmente inseridos na área da bacia, Embu-Guaçu e Itapecerica da Serra, e cinco municípios parcialmente inseridos, Cotia, Embu, Juquitiba, São Lourenço da Serra e São Paulo. A população residente na bacia é de 800 mil pessoas, mas a represa abastece, aproximadamente, 4 milhões de pessoas, pois produz $14 \mathrm{mil} \mathrm{l/s}$ e é um dos principais patrimônios ambientais de São Paulo. A represa Guarapiranga representa $4 \%$ da área da bacia, a área ocupada por atividades humanas representa $42 \%$ da bacia, a área urbana $17 \%$ da bacia e a área com vegetação natural 37\% da bacia (WHATELY; CUNHA, 2006a).

A seguir encontram-se as Figura 3 e 4 que expressam a ocupação e o uso do solo, e a expansão urbana no período de 1999-2003, bem como a localização da sub-bacia no Estado de São Paulo e na RMSP (Figura 4). 


\section{GUARAPIRANGA}

\section{Uso do solo 2003}
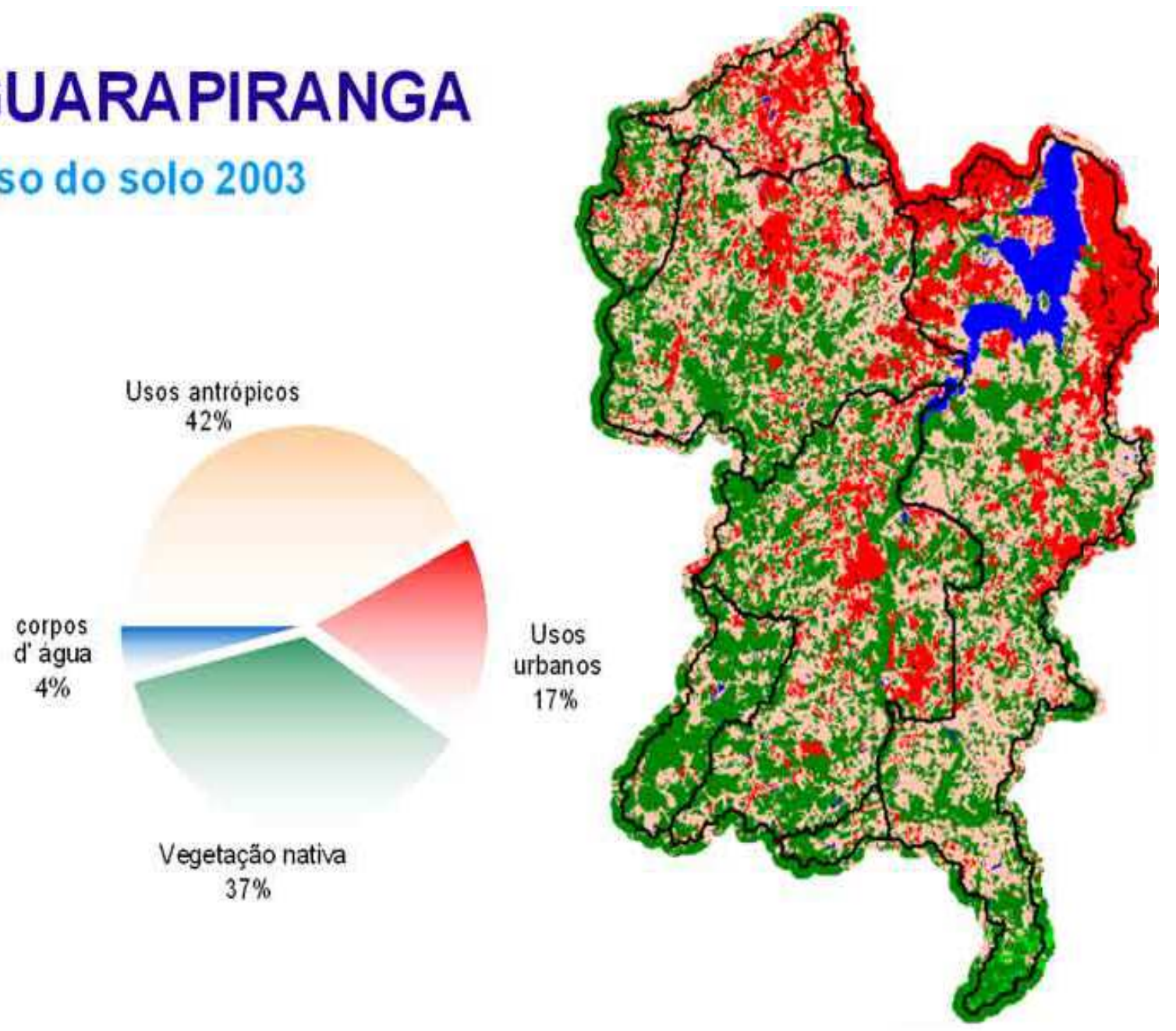

FigURA 3 - Guarapiranga: uso do solo 2003.

FONTE: ISA (2008a). 


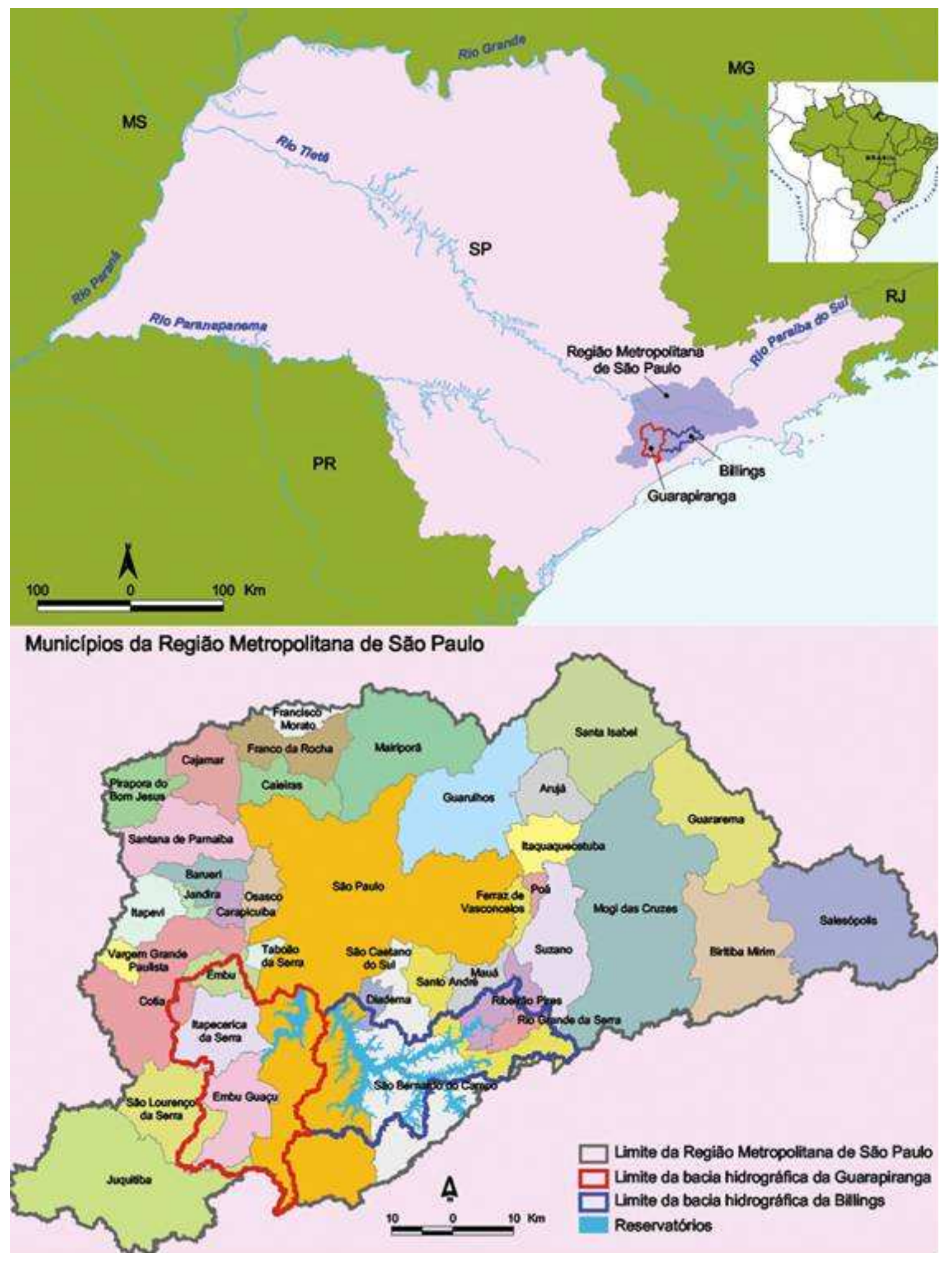

FIGURA 4 - Mapa da sub-bacia hidrográfica Cotia-Guarapiranga.

FONTE: ISA (2008a). 
Quanto à população, os 800 mil habitantes da bacia estão assim distribuídos (Tabela 1):

TABELA 1 - Distribuição da população residente na bacia da Guarapiranga por município, em 2000.

\begin{tabular}{l|c|c}
\multicolumn{1}{c|}{ MUNICÍPIO } & HABITANTES & $\boldsymbol{\%}^{15}$ \\
\hline Cotia & 1.915 & 0,2 \\
\hline Embu & 58.595 & 7,6 \\
\hline Embu-Guaçu & 56.916 & 7,4 \\
\hline Itapecerica da Serra & 129.685 & 16,9 \\
\hline Juquitiba & 1.439 & 0,2 \\
\hline São Lourenço da Serra & 472 & 0,1 \\
\hline São Paulo & 517.788 & 67,5 \\
\hline Capela do Socorro & 232.945 & 30,4 \\
\hline M'Boi Mirim & 208.650 & 27,2 \\
\hline Parelheiros & 76.193 & 9,9 \\
\hline TOTAL NA BACIA & $\mathbf{7 6 6 . 8 1 0}$ & $\mathbf{1 0 0}$ \\
\hline
\end{tabular}

FONTE: Whately e Cunha (2006b, p. 26).

Essa ocupação é representada pela mancha no mapa da expansão urbana (Figura 5).

\footnotetext{
${ }^{15}$ Sobre o total de população residente na Bacia da Guarapiranga em 2000.
} 


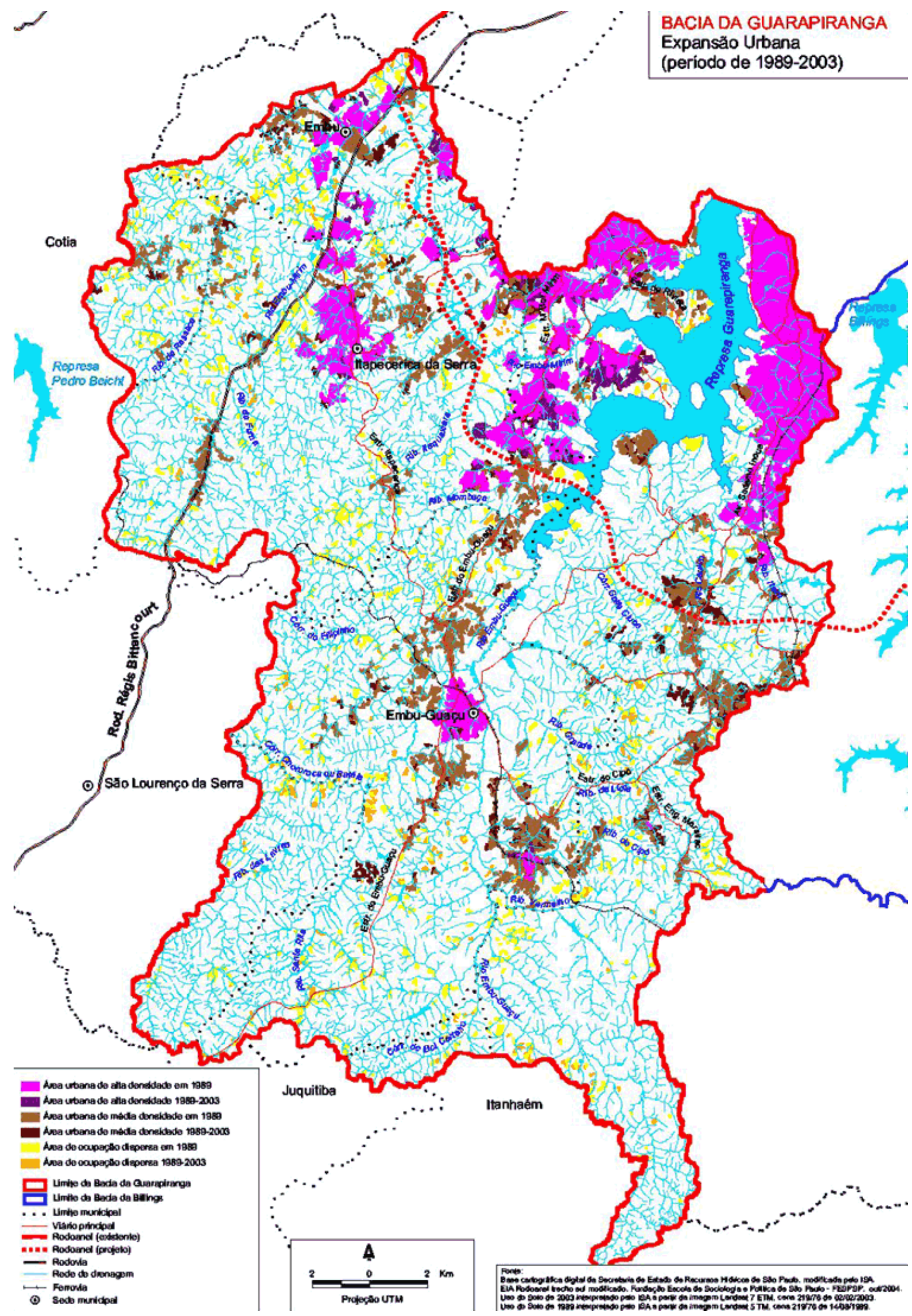

FIGURA 5 - Mapa da bacia Guarapiranga - expansão urbana (1989-2003).

FONTE: ISA (2008a). 


\subsubsection{A PROBLEMÁTICA DA BACIA}

A represa Guarapiranga foi construída entre 1906 e 1909, distante da malha urbana, com a finalidade energética; mas em 1928 tornou-se a principal fonte de água para o abastecimento público de São Paulo. Durante as décadas de 20 a 60, a represa foi marcada pelo processo desordenado de ocupação, elevando o seu nível de poluição orgânica, o que levou já na década de 50 aos primeiros alertas quanto à degradação da qualidade da água e da região da bacia, devido à necessidade de coletores de esgotos (BRANCO; ROCHA, 1977).

As atividades econômicas na bacia são referentes à expansão da RMSP. A primeira fase refere-se à atividade agrícola associada à exploração dos recursos vegetais, que quando chegou à improdutividade do solo deu lugar aos loteamentos clandestinos a espera da valorização imobiliária. A partir de 1960, ocorre a instalação de um polo industrial e a ampliação do centro comercial de Santo Amaro. Na década de 70 diversas indústrias são instaladas na região antes da implementação da Lei de Proteção aos Mananciais. Outra atividade na região é a extração de recursos minerais, areia e argilas, que degradou a paisagem e causou o assoreamento de diversos córregos. Com toda essa expansão, o adensamento urbano e o setor de comércio e serviços ganham intensidade, o que expressa a complexidade do uso do solo na região (GONDOLO, 1996).

Segundo Gondolo (1996), para proteger os mananciais da RMSP, foram aprovadas as Leis n. ${ }^{\circ} 898 / 75$ e 1.172/76 com o objetivo de garantir água em quantidade e qualidade suficientes para o abastecimento de sua população e do setor produtivo, pois as instalações de núcleos urbanos no território da bacia ocorreram, e ainda ocorrem, de forma rápida e descontrolada, agravando a situação em decorrência da inexistência de infraestrutura. Isso porque essas legislações apresentavam rigorosas restrições quanto ao uso das áreas e com isso as mesmas ficaram sem valor, o que levou à ocupação irregular.

No final dos anos 80, ainda se observava os impactos negativos na Guarapiranga, colocando em risco a qualidade das águas da represa e de seus tributários, ameaçando, assim, o abastecimento público. Para minimizar os agravantes, o Poder Público, estadual e municipal que compõem a bacia, implantou na década de 90 o Programa de Saneamento Ambiental da Bacia da Guarapiranga - Programa Guarapiranga (1992-2000), com financiamento do Banco Mundial, que além de obras, serviços e projetos incluiu uma série de estudos sobre a bacia, perpassando as questões de como proceder para uma nova forma de gestão do território capaz 
de equilibrar pressões: o avanço da malha urbana e a preservação das águas da represa e seus afluentes (GONDOLO, 1996).

O objetivo do Programa era o de recuperar e preservar o reservatório Guarapiranga através de um novo modelo de gestão para a bacia, que previa a intervenção conjunta do Estado, dos municípios e da sociedade civil para atuarem nos principais problemas de degradação do manancial. Segundo Gondolo (1996: 9), sua participação na equipe técnica do Programa propiciou observar "as dificuldades encontradas para reverter a situação de degradação do manancial e o distanciamento entre o discurso e a prática, resultante de uma série de condicionantes políticas, econômicas, administrativas e culturais." Isso ocorreu devido ao não comprometimento real dos órgãos responsáveis que retardaram a implementação das ações, levando à multiplicação dos problemas e à aceleração da degradação do manancial.

A extensa ocupação urbana gera riscos extremamente altos de poluição e contaminação de todos os mananciais ali localizados, levando à importação de água de bacias vizinhas, como é o caso do Sistema Cantareira, uma reversão das cabeceiras do Rio Piracicaba, ao norte da bacia do Alto Tietê (SILVA; PORTO, 2003).

De acordo com o ISA (Instituto Socioambiental) (2008a), as principais ameaças na subbacia Guarapiranga dizem respeito à qualidade das águas dos rios da represa que deteriora a cada ano; ao alto custo de tratamento da água, que subiu 133\% entre 1998 e 2003; à redução do espelho d'água do reservatório; à coleta de esgotos em apenas 50\% na região em 2000 e, desse montante, a maioria é despejada na represa; e à ocupação humana com diversos usos nas Áreas de Preservação Permanente (APPs) causando sérias consequências para a produção de água.

Conforme apresenta Gondolo (1996: 21), a ação institucional atuante na bacia é desafiadora, pois "cada órgão com orçamentos e diretrizes próprias de ação, vinculadas a interesses políticos por vezes conflitantes, imprime um determinado ritmo às políticas e ações na bacia."

As ações realizadas na bacia são resultantes de pressões políticas por melhorias de infraestrutura, uma vez que a região tem grande expressividade como zona eleitoral. Essa prática tem consolidado a ocupação e incentivou a abertura de novos loteamentos irregulares (GESP; COBRAPE, 1991 apud GONDOLO, 1996).

"O Estado manteve até 1991 uma posição ambígua na região", pois órgãos do Estado implantaram redes de esgoto, fornecimento de água e energia elétrica em favelas, loteamentos e indústrias clandestinas. A instalação de infraestrutura nessa região favoreceu a proliferação das 
ocupações irregulares, inviabilizando a aplicabilidade da legislação vigente de proteção dos mananciais. Em 1992 foi a vez da ampliação da rede ferroviária e legalização de linhas de ônibus clandestinas, transporte para a região, favorecendo ainda mais a ocupação da região em área de manancial. A sociedade civil estava organizada através de diversas associações que buscavam "favores" do Poder Público sem uma atuação integrada para a proteção do manancial (GONDOLO, 1996).

A seguir encontram-se algumas imagens que demonstram a situação preocupante de degradação na bacia Guarapiranga (Figuras 6, 7, 8 e 9).

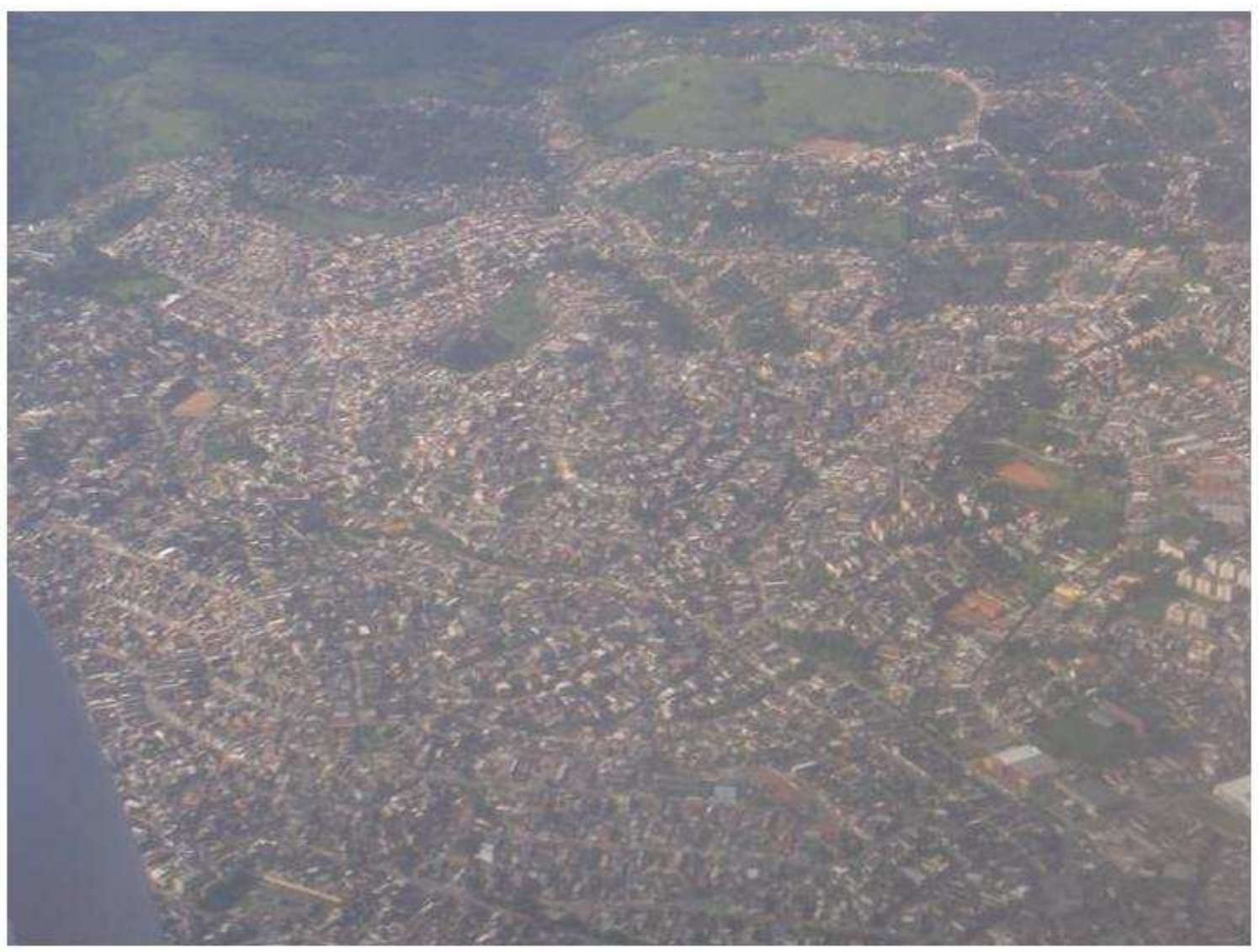

FIGURA 6 - Ocupação urbana em parte da represa Guarapiranga (nov./2009). FONTE: Imagem cedida por Pedro Jacobi. 


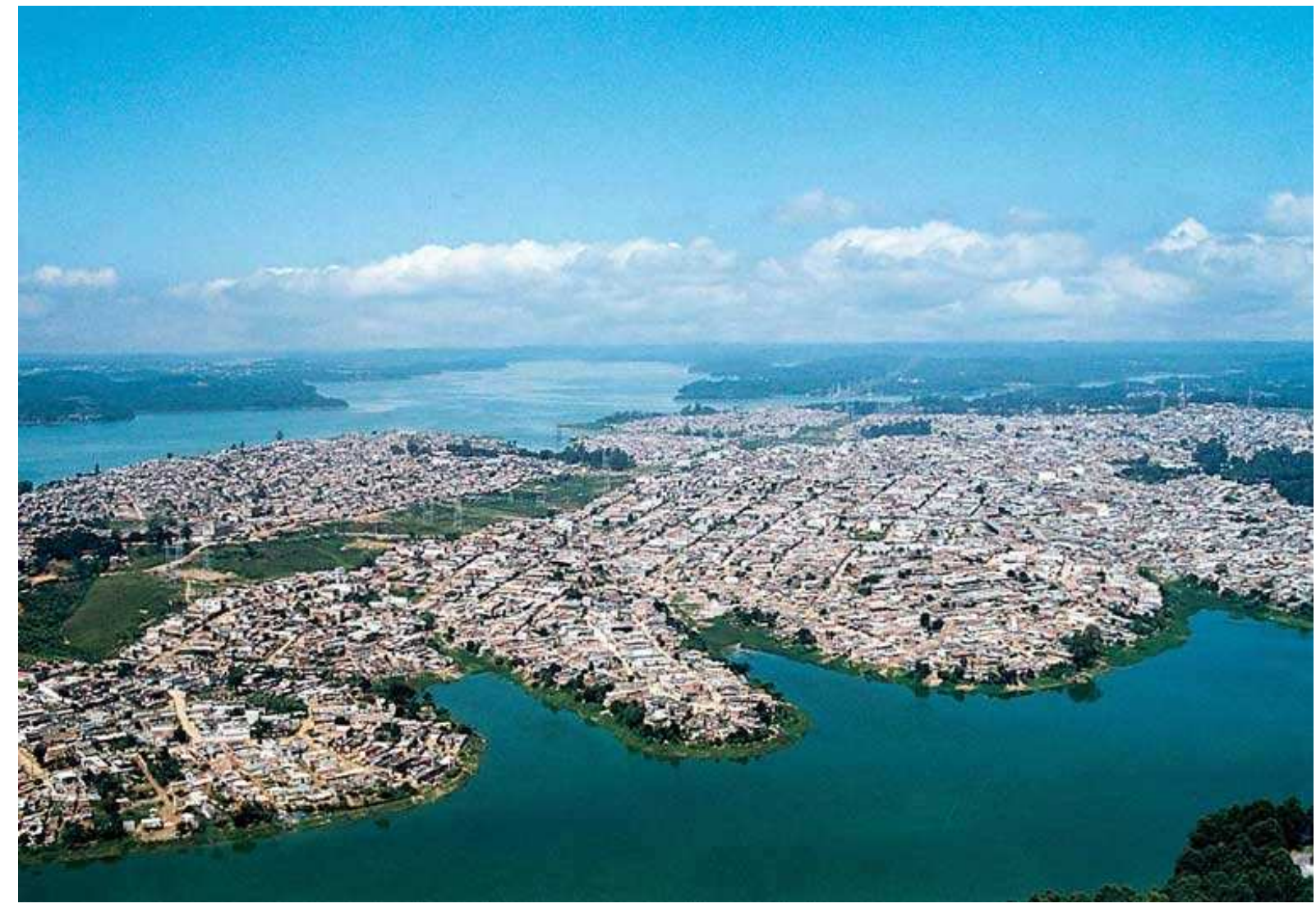

FIGURA 7 - Ocupação urbana em parte da represa Guarapiranga.

FONTE: ISA (2008b).

Assim, diante de tantos problemas, foi criado em 1997 o Subcomitê da Bacia Hidrográfica Cotia-Guarapiranga (SCBH-CG), como será apresentado a seguir.

\subsubsection{SUBCOMITÊ DA BACIA HIDROGRÁFICA COTIA-GUARAPIRANGA}

O Subcomitê da Bacia Hidrográfica Cotia-Guarapiranga (SCBH-CG) foi fundado em 28 de agosto de 1997 e cada mandato tem a duração de dois anos. Sua área geográfica abrange os municípios de Cotia, Embu, Taboão da Serra, Itapecerica da Serra, Embu-Guaçu, Juquitiba, São Lourenço da Serra e São Paulo (Capela do Socorro, M’Boi Mirim e Parelheiros). Antes da criação desse Subcomitê, já existiam na bacia movimentos sociais voltados à preservação ambiental da Guarapiranga. 
O processo de mobilização e organização dos diversos setores para a constituição do Subcomitê foi feito através de reuniões ou grandes eventos, que contaram com a presença de técnicos do Estado e das prefeituras da bacia, e membros da sociedade civil que já militavam na região. Nesse processo é importante destacar o papel que o Programa de Saneamento Ambiental da Bacia do Guarapiranga (Programa Guarapiranga) teve como impulsionador, pois já previa a criação de um órgão colegiado (conselho consultivo) para apoiar as decisões do programa. Esse conselho foi o embrião do Subcomitê.

Um dos assuntos de destaque, antes mesmo da criação do SCBH-CG, era a criação da Lei Específica e do Plano de Desenvolvimento e Proteção Ambiental da Guarapiranga (PDPA). Trata-se de dois instrumentos centrais para o ordenamento do uso, ocupação e preservação da área da bacia. O processo de elaboração da Lei Específica e do PDPA é anterior à constituição do Subcomitê, tendo sido iniciado no âmbito do Programa Guarapiranga.

As leis específicas e os PDPAs estão previstos na Lei n. ${ }^{\circ}$ 7.633/91 (SÃO PAULO, 1991), que especifica que cada comitê de bacia hidrográfica deverá estabelecer os parâmetros de uso e preservação da bacia. A elaboração da minuta de lei específica pode ser considerada um grande avanço no fortalecimento institucional do SCBH-CG, uma vez que ela representou um longo processo de negociações entre Poder Político, seu corpo técnico e administrativo, e representantes do setor privado e da sociedade civil.

Os objetivos do Subcomitê são:

I - promover o gerenciamento descentralizado, participativo e integrado dos recursos hídricos, na sub-região Cotia-Guarapiranga;

II - implantar em sua área de atuação uma política de proteção e recuperação dos mananciais, compatibilizando as ações de preservação dos mananciais de abastecimento e as de proteção ao meio ambiente com o uso e ocupação do solo e o desenvolvimento socioeconômico;

III - atuar em sua área de jurisdição de acordo com os objetivos e atribuições estabelecidos nos Estatutos do CBH-AT (SÃO PAULO, 1997a: 2).

O Subcomitê é formado por representantes do Estado, municípios e sociedade civil, e é constituído pelo Plenário, Grupo Executivo e Câmaras Técnicas. Os representantes do Poder Público, Estado e municípios, são indicados, cabendo aos representantes da sociedade civil o processo de eleição para a escolha de seus representantes. Quanto à mesa diretora, esta é presidida por um representante de prefeitura, a vice-presidência é ocupada por representante da 
sociedade civil, e a secretaria executiva por representante do Estado. No Quadro 1 é apresentada a composição da mesa diretora do Subcomitê Cotia-Guarapiranga, no período de 1999 a 2007.

QUADRO 1 - Composição da mesa diretora do Subcomitê Cotia-Guarapiranga (1999 a 2007).

\begin{tabular}{|l|l|l|l|}
\hline \multicolumn{1}{|c|}{ GESTÕES } & \multicolumn{1}{|c|}{ PRESIDENTE } & \multicolumn{1}{|c|}{ VICE-PRESIDENTE } & \multicolumn{1}{|c|}{ SECRETÁRIO EXECUTIVO } \\
\hline $1999-2000^{16}$ & $\begin{array}{l}\text { Lacir Ferreira Baldusco - } \\
\text { Prefeito de Itapecerica da Serra }\end{array}$ & $\begin{array}{l}\text { Marussia Whately - SOS } \\
\text { Guarapiranga }\end{array}$ & Dagoberto Meneghini - SMA \\
\hline $2001-2002$ & $\begin{array}{l}\text { Lener Nascimento Ribeiro - } \\
\text { Prefeito de São Lourenço da } \\
\text { Serra }\end{array}$ & $\begin{array}{l}\text { Carlos Alberto Pinheiro Souza - } \\
\text { GAIA Mov. Ecológico e Social }\end{array}$ & $\begin{array}{l}\text { Pedro Luiz Ibraim Hallack - } \\
\text { SABESP }\end{array}$ \\
\hline $2003-2004$ & $\begin{array}{l}\text { Walter Antonio Marques - } \\
\text { Prefeito de Embu Guaçu }\end{array}$ & $\begin{array}{l}\text { José Paulino Rocha Ribeiro - } \\
\text { CIESP }\end{array}$ & $\begin{array}{l}\text { Lineu Andrade de Almeida - } \\
\text { SABESP }\end{array}$ \\
\hline $2005-2007$ & $\begin{array}{l}\text { José Merli - P.M. São Lourenço } \\
\text { da Serra }\end{array}$ & $\begin{array}{l}\text { Anselmo José de Almeida (Ney } \\
\text { Favela) - Federação dos } \\
\text { Favelados da Grande São Paulo }\end{array}$ & Mariza G. Prota - SABESP \\
\hline
\end{tabular}

FONTE: Elaborado pela autora.

O Plenário é constituído por 11 representantes dos municípios, 11 do Estado e 11 da sociedade civil. O Grupo Executivo tem formação tripartite e exerce suas funções em articulação com a Secretaria Executiva do CBH-AT, conforme estabelecido no regimento do SCBH-CG (SÃO PAULO, 1997a).

Quanto às Câmaras Técnicas (CT), estas são criadas por deliberação do Plenário do SCBH-CG para um determinado fim, podendo ser permanentes ou transitórias; são coordenadas por um de seus membros, escolhido por seus componentes, e possui as seguintes atribuições, conforme artigo $4^{\circ}$ da deliberação SCBH-CG n. ${ }^{\circ} 09 / 98$ de 03 de dezembro de 1998:

I - Propor minutas de anteprojeto de lei e outros instrumentos legais;

II - Propor critérios e normatizações;

III - Acompanhar estudos, projetos e outros trabalhos relacionados com as suas atribuições;

IV - Subsidiar as discussões do Subcomitê, manifestando-se quando consultado, nas matérias de competência deste;

V - Informar-se sobre as deliberações do Subcomitê, do Conselho Estadual de Recursos Hídricos - CERH, do Comitê Coordenador do Plano Estadual de Recursos Hídricos - CORHI, e de órgãos e Instituições afins que possam

${ }^{16}$ O Presidente e o Secretário Executivo do SCBH-CG exerceram dois mandatos consecutivos e iniciaram a elaboração da minuta da Lei Específica da Guarapiranga. 
subsidiar os trabalhos da Câmara Técnica;

VI - Elaborar seu Regimento Interno, obedecidas as disposições destas normas gerais, para aprovação do Plenário do Subcomitê Cotia-Guarapiranga;

VII - Criar Sub-Câmaras ou Grupos de Trabalho, no âmbito de suas atribuições específicas conforme a natureza e necessidade dos assuntos em discussão;

VIII - Submeter ao Subcomitê os casos omissos e as propostas de alterações nestas nas normas Gerais e do Estatuto do Subcomitê;

IX - Apresentar relatórios, pareceres e propostas decorrentes dos trabalhos para apreciação e decisão do Plenário do Subcomitê;

$\mathrm{X}$ - Subsidiar, no que couber, os trabalhos da Secretaria do Subcomitê e CBHAT a elaboração, avaliação e acompanhamento dos trabalhos pertinentes ao Plano de Bacias Hidrográficas e ao Relatório de Situação dos Recursos Hídricos. (SÃO PAULO, 1999).

Como uma das atribuições da CT, foi criado o Grupo de Trabalho da Lei Específica em maio/1999, sob a coordenação da Prefeitura do Município de São Paulo - Secretaria de Planejamento (SEMPLA), devido à necessidade de informações sobre os assuntos em discussão para aprovação da referida Lei.

Quanto à composição do SCBH-CG, no período das quatro gestões que compreenderam a fase de elaboração da Lei Específica da Guarapiranga, pode-se observar que entre os 22 representantes do Poder Público, tanto do Estado quanto dos municípios, a maioria permaneceu durante todo o processo de elaboração da Lei, mesmo sendo em governos diferentes.

Com relação ao segmento da sociedade civil, dos 11 representantes, $45 \%$ participaram das quatro gestões do SCBH-CG durante a elaboração da Lei, ou seja, participaram de todo o processo de discussão, elaboração até a aprovação. Os outros $45 \%$ participaram de três gestões e a maioria, $72 \%$, participou de duas gestões (ver Anexo 2).

Toda e qualquer intervenção na região da bacia da Guarapiranga precisa respeitar as normas federais e estaduais relativas à proteção ambiental em geral, à proteção dos recursos hídricos e florestais, ao licenciamento de atividades, ao uso e ocupação do solo e aos crimes ambientais, conforme consta no Quadro 2. Portanto, foi necessária a realização de muitos debates e negociações sobre os critérios e normativas relacionadas com essa nova forma de articulação da gestão compartilhada da água com as questões do planejamento e uso do solo. 
QUADRO 2 - Legislação ambiental básica aplicável à bacia hidrográfica da Guarapiranga.

\begin{tabular}{|c|c|}
\hline NÚMERO E ANO & ASSUNTO \\
\hline \multicolumn{2}{|l|}{ FEDERAL } \\
\hline Lei n. ${ }^{\circ} 4.771$ de 1965 & Código Florestal. \\
\hline Lei n. ${ }^{\circ} 6.766$ de 1979 & Parcelamento do solo urbano. \\
\hline Lei n. ${ }^{\circ} 6.902$ de 1981 & $\begin{array}{l}\text { Cria as figuras jurídicas de Estação Ecológica e Área de Proteção } \\
\text { Ambiental (APA). }\end{array}$ \\
\hline Lei n. ${ }^{\circ} 6.938$ de 1981 & Dispõe sobre a Política Nacional de Meio Ambiente. \\
\hline Resolução CONAMA n. $^{\circ} 01$ de 1986 & Dispõe sobre as atividades minerárias. \\
\hline Constituição Federal de 1988 & Artigos 22, 23 e 24, e Capítulo do Meio Ambiente (art. 225). \\
\hline Decreto Federal n. 750 de 1993 & $\begin{array}{l}\text { Regula o corte, a exploração e a supressão de vegetação primária ou } \\
\text { nos estágios avançado e médio de regeneração da Mata Atlântica. }\end{array}$ \\
\hline Resolução CONAMA n. o 01 de 1994 & $\begin{array}{l}\text { Regula o corte, a exploração e a supressão de vegetação primária ou } \\
\text { nos estágios avançado e médio de regeneração da Mata Atlântica no } \\
\text { Estado de São Paulo. }\end{array}$ \\
\hline Lei n. ${ }^{\circ} 9.433$ de 1997 & $\begin{array}{l}\text { Institui a Política Nacional de Recursos Hídricos e cria o Sistema } \\
\text { Nacional de Gerenciamento de Recursos Hídricos. }\end{array}$ \\
\hline Lei n. ${ }^{\circ} 9.605$ de 1998 & $\begin{array}{l}\text { Dispõe sobre as sanções penais e administrativas derivadas de condutas } \\
\text { e atividades lesivas ao meio ambiente - "Lei de Crimes Ambientais". }\end{array}$ \\
\hline Resolução CNRH n. ${ }^{\circ} 12$ de 2000 & $\begin{array}{l}\text { Define critérios para o enquadramento de corpos d'água em classes, } \\
\text { segundo seu uso preponderante. }\end{array}$ \\
\hline Resolução CNRH n. ${ }^{\circ} 16$ de 2000 & Define regras e critérios para outorga e uso de recursos hídricos. \\
\hline Lei n. ${ }^{\circ} 9.985$ de 2000 & $\begin{array}{l}\text { Institui o Sistema Nacional de Unidades de Conservação (SNUC), que } \\
\text { regulamenta a criação e a gestão das unidades de conservação em } \\
\text { território nacional. }\end{array}$ \\
\hline Decreto n. 4.340 de 2002 & $\begin{array}{l}\text { Regulamenta a Lei n. }{ }^{\circ} \text { 9.985/00, que institui o Sistema Nacional de } \\
\text { Unidades de Conservação. }\end{array}$ \\
\hline Resolução CONAMA n. $^{\circ} 357$ de 2005 & $\begin{array}{l}\text { Dispõe sobre a classificação dos corpos de água e diretrizes ambientais } \\
\text { para o seu enquadramento, bem como estabelece as condições e } \\
\text { padrões de lançamentos de efluentes, e dá outras providências. }\end{array}$ \\
\hline \multicolumn{2}{|l|}{ ESTADO DE SÃO PAULO } \\
\hline Lei n. ${ }^{\circ} 898$ de 1975 & Proteção aos Mananciais da Região Metropolitana de São Paulo. \\
\hline Lei n. 997 de 1976 & Dispõe sobre o controle da poluição do meio ambiente. \\
\hline Lei.$^{\circ} 1.172$ de 1976 & Proteção aos Mananciais da Região Metropolitana de São Paulo. \\
\hline Decreto n. ${ }^{\circ} 8.468$ de 1976 & $\begin{array}{l}\text { Estabelece, dentre outras disposições, as classes de uso da água no } \\
\text { Estado e define os seus respectivos parâmetro de qualidade. }\end{array}$ \\
\hline $\begin{array}{l}\text { Constituição do Estado de São Paulo } \\
\text { de } 1989\end{array}$ & $\begin{array}{l}\text { Artigo do Meio Ambiente, dos Recursos Hídricos e do Saneamento - } \\
\text { artigo } 191 \text { a } 213 \text {. }\end{array}$ \\
\hline Lei n. ${ }^{\circ} 7.663$ de 1991 & $\begin{array}{l}\text { Institui a Política e o Sistema Estadual de Gerenciamento de Recursos } \\
\text { Hídricos. }\end{array}$ \\
\hline Lei n. ${ }^{\circ} 9.034$ de 1994 & $\begin{array}{l}\text { Estabelece o primeiro Plano Estadual de Gerenciamento de Recursos } \\
\text { Hídricos. }\end{array}$ \\
\hline Decreto n. ${ }^{\circ} 43.505$ de 1998 & $\begin{array}{l}\text { Autoriza a Secretaria de Meio Ambiente do Estado de São Paulo a } \\
\text { firmar convênios com os Municípios visando à fiscalização e o } \\
\text { licenciamento ambiental. }\end{array}$ \\
\hline Lei n. ${ }^{\circ} 9.509$ de 1997 & Dispõe sobre a Política Estadual de Meio Ambiente. \\
\hline Lei no 9.866 de 1997 & $\begin{array}{l}\text { Estabelece nova lei de Proteção aos Mananciais do Estado de São } \\
\text { Paulo. }\end{array}$ \\
\hline Lei n. ${ }^{\circ} 10.020$ de 1998 & $\begin{array}{l}\text { Autoriza o Poder Executivo a participar da constituição das Fundações } \\
\text { Agências de Bacias Hidrográficas. }\end{array}$ \\
\hline
\end{tabular}




\begin{tabular}{|c|c|}
\hline NÚMERO E ANO & ASSUNTO \\
\hline \multicolumn{2}{|l|}{ ESTADO DE SÃO PAULO } \\
\hline Lei n. $^{\circ} 12.183$ de 2005 & $\begin{array}{l}\text { Dispõe sobre a cobrança pela utilização dos recursos hídricos do } \\
\text { domínio do Estado de São Paulo, os procedimentos para fixação dos } \\
\text { seus limites, condicionantes e valores e dá outras providências. }\end{array}$ \\
\hline Lei n. $^{\circ} 12.233$ de 2006 & Estabelece a área de proteção e recuperação ambiental Guarapiranga. \\
\hline Decreto n. ${ }^{\circ} 51.686$ de 2007 & Regulamenta dispositivos da Lei Estadual n. ${ }^{\circ} 12.233$ de 2006. \\
\hline \multicolumn{2}{|l|}{ MUNICIPAL } \\
\hline Lei n. ${ }^{\circ} 1.238$ de 2001 & $\begin{array}{l}\text { Dispõe sobre o Plano Diretor Estratégico do Município de Itapecerica } \\
\text { da Serra. }\end{array}$ \\
\hline Lei n. 72 de 2003 & Dispõe sobre o Plano Diretor do Município de Embu. \\
\hline Lei n. $^{\circ} 13.885$ de 2004 & $\begin{array}{l}\text { Estabelece normas complementares ao Plano Diretor Estratégico, } \\
\text { institui Planos Regionais Estratégicos das Subprefeituras, dispõe sobre } \\
\text { o parcelamento, disciplina e ordena o Uso e Ocupação do Solo do } \\
\text { Município de São Paulo. }\end{array}$ \\
\hline
\end{tabular}

FONTE: Whately e Cunha (2006a: 25).

\subsection{Lei de ProteÇão aos MananCiais (Lei N.o 9.866/97)}

A população da RMSP aumentou de quatro milhões de habitantes em 1960 para quase 10 milhões em 1975, atingindo 18,3 milhões em 2005 e com projeção de 20,5 milhões em 2015 (EMPLASA, 2009). Essa ocupação ocorreu em áreas distantes dos centros urbanizados de maneira desordenada, obedecendo em muitos casos uma lógica especulativa e com um impacto direto na qualidade ambiental, notadamente nos mananciais (SÃO PAULO, 2004).

Na década de 70 as discussões sobre a questão metropolitana levaram à aprovação das Leis de Proteção aos Mananciais, Leis n. ${ }^{\circ}$ 898/75 e n. ${ }^{\circ}$ 1.172/76. A Lei n. ${ }^{\circ}$ 898/75 disciplinava o uso e ocupação do solo e a Lei n. ${ }^{\circ}$ 1.172/76 definia as áreas de proteção e estabelecia o zoneamento, objetivando a proteção dos mananciais. Essas legislações visavam critérios técnicos para o uso e ocupação do solo. Quanto mais próximo do manancial protegido, mais baixa era a densidade de ocupação permitida. Essas Leis estipulavam as formas de uso, parcelamento do solo e assentamentos industriais compatíveis com a produção de água na região (ISA, 2008a).

Diante do impasse sobre a competência dos órgãos públicos, essa legislação, somada às ações de outras políticas públicas contrárias à preservação dos mananciais, não conseguiu interromper o processo de expansão urbana para as áreas protegidas, reforçando as precárias 
condições de habitação, clandestinidade no parcelamento do solo e elevadas densidades demográficas. Essas Leis representaram um avanço na questão da gestão integrada, mas não foram eficazes, devido à ausência de políticas setoriais integradas para a aplicação das referidas Leis, o que acabou por favorecer a continuidade das ocupações em áreas de mananciais.

Segundo Gondolo (1996: 25),

apesar das restrições impostas pela lei, as áreas protegidas sofreram, sistematicamente, ocupações irregulares. A pressão gerada pela expansão urbana, a pouca eficiência da fiscalização, a falta de comprometimento político dos municípios no cumprimento da lei, levaram, como vimos, à proliferação de loteamentos populares clandestinos, à ocorrência de invasões e à formação de inúmeras favelas e áreas de marginalidade urbana.

Após 20 anos de legislação verificou-se a distância entre a intenção de proteger os mananciais e a sua situação real. A legislação não dava conta dos seus objetivos. Isso demonstrou que a atuação do Poder Público não foi eficaz, pois não atuou de forma preventiva na região dos mananciais para controlar os impactos da ocupação descontrolada, a qual acentua a ocupação irregular do solo com impactos sobre o meio ambiente, em particular os recursos hídricos.

Nesse sentido, buscou-se alterar a legislação da década de 70, para criar condições de gestão descentralizada e participativa, e atenuar os impactos sobre a qualidade das águas. Foi aprovada, então, a Lei n. ${ }^{\circ}$ 9.866/97 que dispõe sobre diretrizes e normas para a proteção e recuperação das bacias hidrográficas dos mananciais de interesse regional do Estado de São Paulo, definindo a necessidade de elaboração de leis específicas para os mananciais (SÃO PAULO, 1997b).

Além dos motivos anteriormente elencados, outros também corroboraram para a mudança na legislação, como o fato de ter se verificado que a ocupação ocorreu de forma contrária aos cenários previstos pela Lei, propiciando um conjunto de irregularidades com impactos negativos na qualidade da água. Dessa forma, houve a necessidade de se ampliar a abrangência da legislação existente, pois era restrita à proteção de alguns mananciais responsáveis pelo abastecimento da RMSP. Outro fator está relacionado à imprescindibilidade de compatibilizar as ações de preservação dos mananciais e proteção ao meio ambiente com o uso e ocupação do solo e o desenvolvimento socioeconômico das regiões protegidas. 
Nesse contexto, outros fatores são somados para a alteração da legislação: a necessidade de inclusão da dimensão participativa da Constituição de 1988 e a implantação da Política Nacional de Recursos Hídricos, que desmontava a legislação autoritária caracterizada pela não participação da sociedade na gestão pública (BRASIL, 1997, 2003). Tais fatores configuram a transição de uma gestão centralizada para uma gestão descentralizada e participativa, com a finalidade de concretizar a eficiência e eficácia da proteção dos mananciais, que demandam articulação, integração e cooperação entre os atores envolvidos.

Outro grande diferencial que a Lei determina é a descentralização dos procedimentos para licenciamento, fiscalização e monitoramento a serem feitos pelas prefeituras ou por estas em conjunto com o Estado. Isso porque, diante da nova conjuntura política brasileira, ocorreram processos democráticos de discussão para a elaboração de leis que envolvessem todos os setores da sociedade na busca de soluções. Nesse formato foi aprovada a Lei n. ${ }^{\circ}$ 9.866/97, que apresenta a gestão da água de forma integrada com a gestão do solo; adota a bacia hidrográfica como unidade de planejamento e gestão; propõe a criação de Áreas de Proteção e Recuperação de Mananciais (APRMs); cria as Áreas de Intervenção (ARO, AOD e ARA) (Figura 8) e propõe instrumentos de gestão (Quadro 3); vincula a gestão dos mananciais ao Sistema Integrado de Gerenciamento de Recursos Hídricos; e direciona para a necessidade de ser promulgada Leis Específicas para cada APRM.

QUADRO 3 - Instrumentos da Lei Estadual n. ${ }^{\circ}$ 9.866/97.

\begin{tabular}{|c|c|}
\hline INSTRUMENTOS & OBJETIVOS \\
\hline $\begin{array}{l}\text { Leis específicas para cada } \\
\text { APRM }\end{array}$ & $\begin{array}{l}\text { Estabelecer as diretrizes e normas direcionadoras de uso e ocupação do solo e } \\
\text { parâmetros ambientais "garantidores dos padrões de qualidade e quantidade de } \\
\text { água". }\end{array}$ \\
\hline $\begin{array}{l}\text { Plano de Desenvolvimento e } \\
\text { Proteção Ambiental (PDPA) }\end{array}$ & $\begin{array}{l}\text { Instituir o Plano de Desenvolvimento Estadual, resultado do planejamento de ações } \\
\text { estratégicas para a proteção e recuperação das bacias, e consolidação das } \\
\text { intervenções e investimentos, assim como das diretrizes e metas, com revisão a } \\
\text { cada } 4 \text { anos. }\end{array}$ \\
\hline Áreas de Intervenção & $\begin{array}{l}\text { Em lugar de uma lei estadual de uso e ocupação do solo que traga um zoneamento } \\
\text { que desconsidere as realidades locais, a proposta sugere Áreas de Intervenção onde } \\
\text { deverão ocorrer ações de recuperação das áreas degradadas em decorrência de } \\
\text { ocupações predatórias, bem como ações indutoras de usos e atividades compatíveis } \\
\text { com a recuperação dos mananciais. São elas: Área de Restrição à Ocupação } \\
\text { (ARO), Áreas de Ocupação Dirigida (AOD) e Áreas de Recuperação Ambiental } \\
\text { (ARA). }\end{array}$ \\
\hline Licenciamento e fiscalização & Controlar as atividades e ocupação do território. \\
\hline Sistema de monitoramento & Acompanhar a evolução dos indicadores de qualidade ambiental. \\
\hline Suporte financeiro & Garantir fontes de recursos para as ações de controle e os investimentos \\
\hline Sistema de informações & $\begin{array}{l}\text { Criar sistema informatizado e georreferenciado contendo banco de dados atualizado } \\
\text { e compartilhado entre os agentes que atuam na bacia. }\end{array}$ \\
\hline
\end{tabular}

FONTE: Whately, Santoro e Tagnin (2008: 8). 
As áreas de proteção e recuperação aos mananciais devem ser criadas por Lei Específica, que também estabelecerá as áreas de intervenção e as respectivas normas ambientais e urbanísticas de interesse regional para a proteção e recuperação dos mananciais.

Dentre os instrumentos da Lei, o PDPA tem por objetivo viabilizar um modelo de gestão integrada da região, contando com a participação da sociedade civil e dos Poderes Público local e estadual, a fim de fazer cumprir o que estabelece as políticas setoriais relativas à habitação, transporte, manejo de recursos naturais, saneamento ambiental e infraestrutura que interferem na qualidade dos mananciais.

O PDPA também tem por finalidade a apresentação de um diagnóstico da ocupação da bacia, com base em estudos de natureza multidisciplinar. Ele articula os planos, programas e projetos intervenientes na bacia, estabelecendo metas, políticas de atuação e diretrizes técnicas de gestão e seus desdobramentos. Esse Plano precisa ser revisto a cada quatro anos, pois é imprescindível que todo o instrumental proposto seja discutido, atualizado e aprimorado, incorporando as inovações que se mostrarem emergentes, tendo sempre a execução dos demais instrumentos da Lei para a obtenção do êxito.

Com a aprovação da Lei n. ${ }^{\circ}$ 9.866/97 ocorre uma nova abordagem da preservação dos recursos hídricos, pois esta reconhece a especificidade de cada bacia ou sub-bacia, introduz a gestão descentralizada de recursos hídricos por bacia ou sub-bacia e a participação comunitária na gestão das bacias ou sub-bacias. Isso demonstra que essa Lei superou o controle normativo da legislação anterior relativa à proteção dos mananciais, que tratava por igual todas as subbacias da RMSP, não protegia suficientemente os mananciais e tampouco controlava efetivamente a ocupação humana das vertentes tributárias desses mananciais, como explicado anteriormente.

Para atender a essa especificidade da nova Lei, cada bacia ou sub-bacia elaborará sua Lei Específica para gerenciar os recursos hídricos, o uso e a ocupação do solo em áreas de mananciais. Nesse contexto legal e institucional, a gestão dos mananciais da RMSP passa a ter uma gestão tripartite entre os representantes do Poder Público, Estado e municípios, e da sociedade civil organizada. Mas essa mudança é um processo moroso e para exemplificá-lo será apresentado no item a seguir o processo de negociação ocorrido para a aprovação da Lei Específica da Guarapiranga (Lei n. $\left.{ }^{\circ} 12.233 / 06\right)^{17}$, primeira lei elaborada no Estado de São Paulo.

\footnotetext{
${ }^{17}$ São Paulo (2006).
} 


\subsection{LEI ESPECÍ́FICA DA GUARAPIRANGA (LEI N. 12.233/06): ORGANIZAÇÃo, ATORES ENVOLVIDOS E PROCESSO DE APRENDIZAGEM SOCIAL}

A Lei n. ${ }^{\circ}$ 12.233, aprovada em 16 de janeiro de 2006, define a Área de Proteção e Recuperação dos Mananciais da Bacia Hidrográfica do Guarapiranga (APRM-G) em cumprimento ao artigo $4^{\circ}$ da Lei Estadual n. ${ }^{\circ} 9.866 / 97$ (SÃO PAULO, 1997b). Seus objetivos são:

I - implementar a gestão participativa e descentralizada da APRM-G, integrando setores e instâncias governamentais e a sociedade civil;

II - integrar os programas e políticas regionais e setoriais, especialmente aqueles referentes à habitação, transporte, saneamento ambiental, infraestrutura e manejo de recursos naturais e geração de renda, necessários à preservação do meio ambiente;

III - estabelecer as condições e os instrumentos básicos para assegurar e ampliar a produção de água para o abastecimento da população, promovendo as ações de preservação, recuperação e conservação dos mananciais da Bacia Hidrográfica do Guarapiranga;

IV - garantir as condições necessárias para atingir a Meta de Qualidade da Água do Reservatório Guarapiranga, estabelecida nesta lei;

V - disciplinar o uso e ocupação do solo na APRM-G, de maneira a adequá-los aos limites de cargas poluidoras definidos para a Bacia e às condições de regime e produção hídrica do manancial;

VI - compatibilizar o desenvolvimento socioeconômico com a proteção e recuperação do manancial;

VII - incentivar a implantação de atividades compatíveis com a proteção e recuperação do manancial;

VIII - estabelecer diretrizes e parâmetros de interesse regional para a elaboração das leis municipais de uso, ocupação e parcelamento do solo, com vistas à proteção do manancial;

IX - disciplinar e reorientar a expansão urbana para fora das áreas de produção hídrica e preservar os recursos naturais;

X - promover ações de Educação Ambiental. (SÃO PAULO, 2006).

A Lei Específica da Guarapiranga permitirá o desenvolvimento de ações para recuperar, adequar e regularizar as ocupações irregulares e clandestinas existentes na bacia hidrográfica da Guarapiranga, resultantes dos parâmetros restritivos vigentes até 1997, quando a Lei de 1975 foi substituída. Também viabilizará a regularização de atividades hoje irregulares, além de possibilitar a instalação de atividades econômicas compatíveis com a proteção dos mananciais. 
Essa Lei define o que deve ser feito na APRM-G, contemplando: áreas de intervenção, metas de qualidade ambiental, normas para implantação de infraestrutura de saneamento ambiental, mecanismos de compensação, monitoramento da qualidade ambiental - sistema gerencial de informações, licenciamento, fiscalização e penalidades -, bem como a compatibilidade com outras leis ambientais e de gestão de recursos hídricos, conforme apresentado no Quadro 2 (Legislação básica aplicável à bacia da Guarapiranga).

O fator inovador dessa Lei é o vínculo do ordenamento do uso do solo à capacidade de suporte da bacia, estabelecendo a corresponsabilidade do Poder Público, Estado e municípios, e da sociedade civil no processo de gestão compartilhada de recursos hídricos, visando à adequada manutenção da qualidade da água em virtude da apropriada ocupação e uso do solo na bacia.

As áreas de intervenção criadas na APRM-G orientam quanto à implantação de políticas públicas direcionadas à proteção, recuperação e preservação dos mananciais, como são detalhadas a seguir e ilustradas na Figura 8.

I - Áreas de Restrição à Ocupação (ARO): são aquelas com especial interesse para a preservação, conservação e recuperação dos recursos naturais da bacia;

II - Áreas de Ocupação Dirigida (AOD): são as de interesse para a consolidação ou implantação de usos urbanos e rurais, desde que atendidos os requisitos que assegurem a manutenção das condições ambientais necessárias à produção de água em quantidade e qualidade para o abastecimento público. III - Áreas de Recuperação Ambiental (ARA): são ocorrências localizadas de usos ou ocupações que estejam comprometendo a quantidade e a qualidade das águas, exigindo intervenções urgentes de caráter corretivo. (SÃO PAULO, 2006). 


\section{ÁREAS DE INTERVENÇÃO APRM - GUARAPIRANGA}

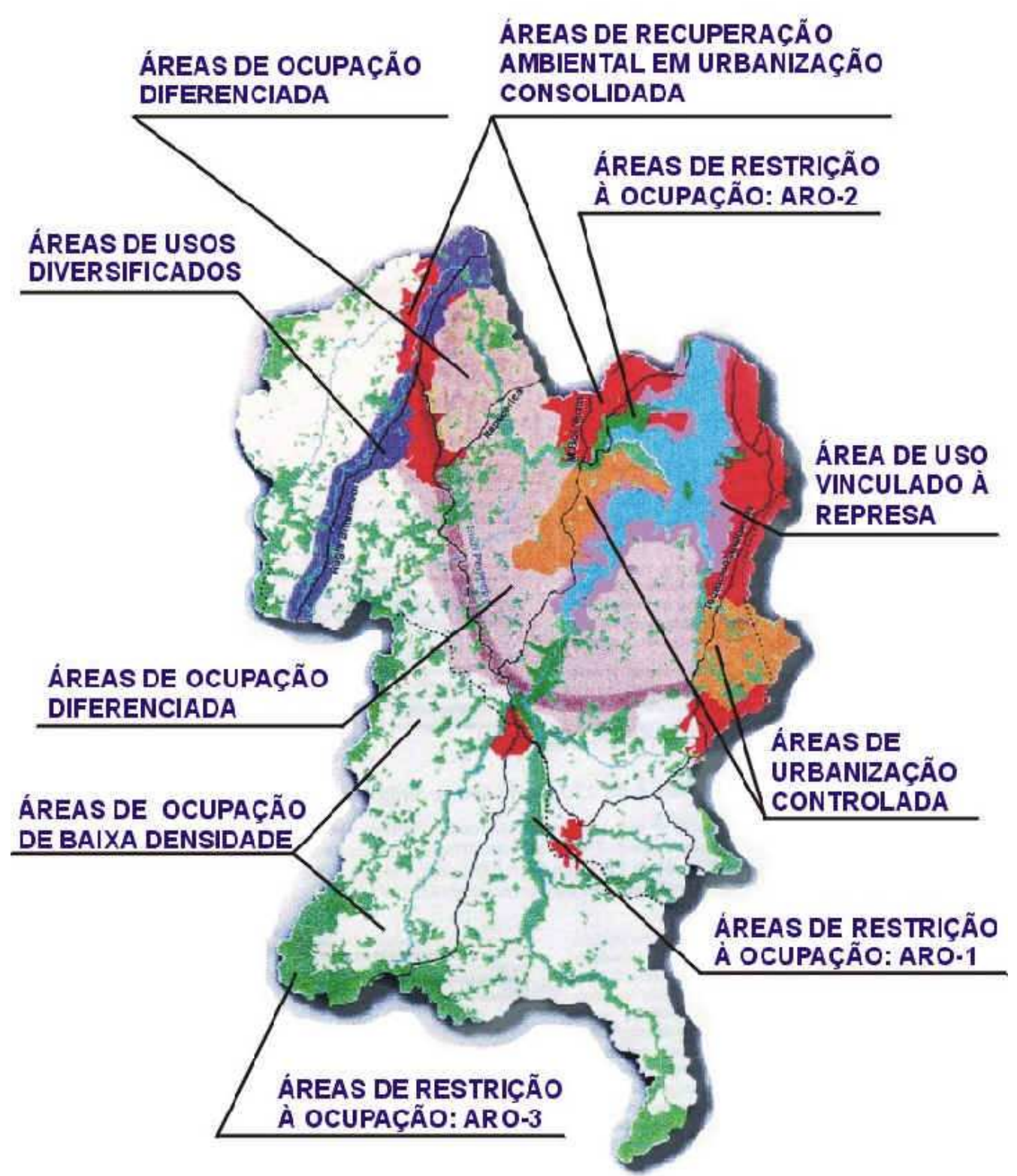

FIGURA 8 - Mapa das áreas de intervenção na Guarapiranga. FONTE: SIGRH (2008).

Mas para que a implementação da Lei Específica seja bem-sucedida, é necessário que haja um pacto entre os atores envolvidos, pois a experiência com as legislações anteriores, com mecanismos de comando e controle, demonstrou não ser suficiente para conter a degradação dos mananciais da RMSP. A Lei n. ${ }^{\circ}$ 12.233/06 prevê a gestão descentralizada, integrada e de responsabilidade compartilhada. Desse modo, o êxito dessa Lei só será possível quando o Governo do Estado, que tem posição de liderança nesse processo, criar as condições para 
implementar definitivamente a política de proteção e recuperação aos mananciais (WHATELY; CUNHA, 2006b).

Diante desse desafio, apresenta-se a seguir o processo de elaboração da Lei Específica da Guarapiranga, por ter configurado um instrumento de cooperação entre Poder Público, estadual e municipal, e a sociedade civil visando concretizar a articulação para a gestão compartilhada de recursos hídricos e integrada com a gestão do uso e ocupação do solo. Assim como essa Lei e a da Billings, recentemente sancionada pelo Governador José Serra em 24 de setembro de 2009, as demais leis específicas estão em fase de elaboração e debate pelos subcomitês, pois, além de todos os motivos elencados, essas Leis constituem-se em condição para a regulamentação da cobrança pelo uso da água.

\subsubsection{Processo de ELABORAÇÃo da LeI ESPECÍfICA DA GUARAPIRANGA}

Neste item são apresentados os aspectos gerais da elaboração da Lei, processo, atores e debates. A ênfase é na dinâmica dos atores envolvidos, com o detalhamento dos problemas, conflitos e negociações até a aprovação do decreto que regulamenta a Lei.

O período de negociação até a aprovação da referida Lei foi de oito anos (1999 a 2006) e se estendeu ao longo de quatro gestões do SCBH-CG, o que implicou na rotatividade dos atores na mesa de negociação e divergências políticas partidárias em cada gestão, comprometendo a continuidade da elaboração da Proposta de Lei.

Os atores que participaram do processo de negociação para aprovação da Lei foram os representantes do Poder Público, estadual e municipal, e da sociedade civil organizada no SCBH-CG e demais esferas da gestão compartilhada das águas. Os interesses em negociação compreendiam os dos atores envolvidos e da população atendida com o fornecimento de água da represa Guarapiranga, o que representa cerca de 4 milhões de pessoas.

A discussão para a elaboração da proposta da Lei Específica da Guarapiranga ocorreu no Grupo de Trabalho do Subcomitê da Bacia Hidrográfica Cotia-Guarapiranga, no âmbito de sua Câmara Técnica de Planejamento e Gestão, tendo sido desenvolvida no período de maio de 1999 a setembro de 2000. A discussão iniciou-se com base no Plano de Desenvolvimento e Proteção Ambiental Guarapiranga e na Minuta da Lei Específica, enviados ao SCBH-CG pelas 
Secretarias Estaduais de Recursos Hídricos, Saneamento e Obras e do Meio Ambiente. O processo de discussão compreendeu reuniões temáticas, abertas a todos os interessados da bacia, e foram realizadas em Itapecerica da Serra e Embu-Guaçu, por serem dois municípios que estão totalmente inseridos na bacia (COMITE-AT, 2008).

As propostas apresentadas, resultado de muitos debates, foram sistematizadas pelo GT Lei Específica, composto por representantes dos três segmentos que integram o SCBH-CG, e discutidas em reuniões públicas em Embu-Guaçu, Itapecerica da Serra e São Paulo. As reuniões serviram como espaços para a divulgação e ampliação dos debates sobre a Lei. A divulgação ocorreu com cartazes nos estabelecimentos comerciais, escolas, nos jornais locais e boletins institucionais. Essa forma de comunicação apoiou-se num formato de linguagem popular para melhor e maior envolvimento de todos os atores.

As linhas que nortearam os trabalhos do GT foram: a inclusão de critérios e parâmetros para a aplicação imediata da Lei Específica; os limites geográficos das áreas de intervenção adequados à realidade da ocupação dos municípios; a definição das competências municipais referentes ao licenciamento, fiscalização e gestão da APRM-G; a articulação entre os instrumentos de compensação e regularização previstos na Lei, e os objetivos de recuperação e preservação da bacia; e a definição de prioridades e a operacionalização dos instrumentos de gestão, para garantir a implementação de programas e projetos de recuperação, preservação e apoio ao desenvolvimento sustentável (COMITE-AT, 2008).

A seguir apresenta-se a cronologia do processo de elaboração da Lei (Quadro 4). 
QUADRO 4 - Cronologia dos instrumentos legais relativos à Lei Específica da APRM-G.

\begin{tabular}{|c|c|c|c|}
\hline ANO & ANO/ DATA & $\begin{array}{l}\text { INSTRUMENTO } \\
\text { JURÍDICO }\end{array}$ & OBJETO/ EVENTO \\
\hline $1999 / 2001$ & $1999-2001$ & $\begin{array}{l}\text { Minuta de PL } \\
\text { Guarapiranga }\end{array}$ & $\begin{array}{l}\text { Elaboração da minuta de PL Guarapiranga: minuta inicial } \\
\text { elaborada pela Secretaria do Meio Ambiente (SMA) (1999), } \\
\text { com base em estudos da SMA e da Secretaria de Energia, } \\
\text { Recursos Hídricos e Saneamento. Essa minuta foi discutida, } \\
\text { ajustada e reformatada no GT Lei Específica - Grupo } \\
\text { Técnico da Câmara de Planejamento e Gestão do Subcomitê } \\
\text { Cotia-Guarapiranga, coordenado por representante da } \\
\text { Prefeitura Municipal de São Paulo e contou com a } \\
\text { participação de integrantes da sociedade civil, municípios e } \\
\text { Estado (trabalhos concluídos em 2001). }\end{array}$ \\
\hline \multirow{2}{*}{2001} & NOV/2001 & $\begin{array}{l}\text { Minuta de PL } \\
\text { Guarapiranga }\end{array}$ & Subcomitê aprova minuta do PL Cotia-Guarapiranga. \\
\hline & 19/DEZ/2001 & $\begin{array}{l}\text { Minuta de PL } \\
\text { Guarapiranga }\end{array}$ & $\begin{array}{l}\text { Comitê da Bacia do Alto-Tietê aprova minuta do PL } \\
\text { Guarapiranga (Deliberação n. }{ }^{\circ} 06 \text { de 19/12/2001). }\end{array}$ \\
\hline \multirow[b]{3}{*}{2002} & $15 / \mathrm{JAN} / 2002$ & $\begin{array}{l}\text { Minuta de PL } \\
\text { Guarapiranga }\end{array}$ & $\begin{array}{l}\text { Conselho Estadual de Recursos Hídricos aprova minuta do } \\
\text { PL Guarapiranga (Deliberação n. }{ }^{\circ} 34 \text { de 15/01/2002). }\end{array}$ \\
\hline & 13/AGO/2002 & $\begin{array}{l}\text { Minuta de PL } \\
\text { Guarapiranga }\end{array}$ & $\begin{array}{l}\text { Conselho Estadual de Meio Ambiente (CONSEMA) aprova } \\
\text { minuta do PL Guarapiranga com recomendações } \\
\left.\text { (Deliberação n. }{ }^{\circ} 15 \text { de } 13 / 08 / 2002\right) \text {. }\end{array}$ \\
\hline & 13/AGO/2002 & $\begin{array}{l}\text { Minuta de PL } \\
\text { Guarapiranga }\end{array}$ & $\begin{array}{l}\text { CONSEMA, em sua } 178^{\text {a }} \text { reunião plenária ordinária, aprova } \\
\text { o relatório da Comissão Mista Permanente de Articulação e } \\
\text { Integração do CONSEMA com o CERH e com o } \\
\text { CONESAN sobre a minuta de anteprojeto de lei que define a } \\
\text { área de recuperação e proteção dos mananciais da bacia } \\
\text { hidrográfica Guarapiranga. }\end{array}$ \\
\hline \multirow[t]{2}{*}{2004} & 29/FEV/2004 & PL 85/2004 & $\begin{array}{l}\text { Encaminhado à ALESP o PL } 85 \text { (Lei Específica da } \\
\text { Guarapiranga). }\end{array}$ \\
\hline & 04/MAR/2004 & PL 85/2004 & Publicado no Diário da Assembléia, página 14. \\
\hline \multirow{4}{*}{2005} & 14/SET/2005 & PL 85/2004 & $\begin{array}{l}\text { Audiência Pública realizada para apresentação e discussão do } \\
\text { PL } 85 \text { - CEU Cidade Dutra. }\end{array}$ \\
\hline & 29/SET/2005 & PL 85/2004 & $\begin{array}{l}\text { Audiência Pública realizada para apresentação e discussão do } \\
\text { PL } 85 \text { - Câmara Municipal de Itapecirica da Serra. }\end{array}$ \\
\hline & 05/OUT/2005 & PL 85/2004 & $\begin{array}{l}\text { Audiência Pública realizada para apresentação e discussão do } \\
\text { PL } 85 \text { - Assembléia Legislativa do Estado de São Paulo. }\end{array}$ \\
\hline & 21/DEZ/2005 & PL 85/2004 & $\begin{array}{l}\text { Assembléia Legislativa do Estado de São Paulo aprova o PL } \\
85 \mathrm{com}^{2} \text { a Emenda } \text {. }^{\circ} 52 \text { (modificação do lote mínimo para } \\
250 \mathrm{~m}^{2} \text { ) em sua } 70^{\mathrm{a}} \text { sessão Extraordinária da Assembléia } \\
\text { Legislativa }\end{array}$ \\
\hline \multirow{5}{*}{2006} & 16//JAN/2006 & Lei 12.233/06 & $\begin{array}{l}\text { Poder Executivo sanciona a Lei Específica da Guarapiranga } \\
\text { n. }{ }^{\circ} 12.233 \text {, que define a Área de Proteção e Recuperação dos } \\
\text { Mananciais da Bacia Hidrográfica do Guarapiranga, e dá } \\
\text { outras providências correlatas. }\end{array}$ \\
\hline & 23/JAN/2006 & $\begin{array}{l}\text { Regulamentação } \\
\text { da Lei } 12.233 / 06\end{array}$ & $\begin{array}{l}\text { Criação do Grupo de Trabalho (GT) Estado, por meio da } \\
\text { Resolução SMA } 002 \text { de 23/JAN/06 e } 008 \text { de FEV/06. }\end{array}$ \\
\hline & 29/JUN/2006 & $\begin{array}{l}\text { Regulamentação } \\
\text { da Lei } 12.233 / 06\end{array}$ & $\begin{array}{l}\text { Entrega ao Secretário de Meio Ambiente de minuta de } \\
\text { regulamentação da Lei n. }{ }^{\text {o }} 12.233 / 06 \text { desenvolvida na } \\
\text { Câmara Técnica do Subcomitê Cotia-Guarapiranga. }\end{array}$ \\
\hline & 12/JUL/2006 & $\begin{array}{l}\text { Regulamentação } \\
\text { da Lei } 12.233 / 06\end{array}$ & $\begin{array}{l}\text { Finalização dos trabalhos do GT-Estado, propondo minuta de } \\
\text { regulamentação da Lei n. }{ }^{\circ} \text { 12.233/06. }\end{array}$ \\
\hline & 12/DEZ/2006 & $\begin{array}{l}\text { Regulamentação } \\
\text { da Lei } 12.233 / 06\end{array}$ & $\begin{array}{l}\text { Subcomitê aprova minuta de regulamentação da Lei } \text { n. }^{\circ} \\
12.233 / 06 \text {. }\end{array}$ \\
\hline
\end{tabular}




\begin{tabular}{|c|c|c|l|}
\hline ANO & ANO/ DATA & $\begin{array}{c}\text { INSTRUMENTO } \\
\text { JURÍDICO }\end{array}$ & \multicolumn{1}{c|}{ OBJETO/ EVENTO } \\
\hline 2007 & $22 / \mathrm{MAR} / 2007$ & Decreto n. ${ }^{\circ} 51.686$ & $\begin{array}{l}\text { Poder Executivo edita regulamento dos dispositivos da Lei } \\
\text { Estadual n. }{ }^{\circ} 12.233 / 06, \text { de 16 de Janeiro de 2006 - Lei } \\
\text { Específica da Guarapiranga, que define a Área de Proteção e } \\
\text { Recuperação dos Mananciais da Bacia Hidrográfica do } \\
\text { Guarapiranga (APRM-G). }\end{array}$ \\
\hline
\end{tabular}

FONTE: Cronologia sistematizada por Valentina Denizo - CDHU, cedida à autora em novembro de 2009.

Os diferentes segmentos participaram do processo a partir de 1999, trabalhando com a minuta inicial elaborada pela SMA e encaminhada para discussão no SCBH-CG e no AT, os quais a aprovaram no final de 2001. Em 2002 o Conselho Estadual de Recursos Hídricos $(\mathrm{CERH})$ aprovou a minuta, bem como o CONSEMA, porém com recomendações. No ano de 2003 ocorreu uma interrupção do processo em virtude da tensão provocada pelo encaminhamento do PL 85/2002 que altera o artigo 53 da Lei de Mananciais. Vive-se o impasse da Lei Tripoli (como ficou conhecida).

O impasse ocorreu porque o PL 85/2002 alterava o artigo 53 da Lei de Mananciais, propondo a regularização dos imóveis localizados nos mananciais da RMSP que excedessem as densidades atualmente permitidas, por meio da compra de uma nova área dentro da mesma bacia hidrográfica, destinada à preservação ambiental da região como forma de compensação. Mas essa proposta gerou polêmica, pois não existia um planejamento ambiental prévio que determinasse quais seriam as áreas escolhidas para compensação. Outro ponto conflitante refere-se à inviabilidade de fiscalização da proposta, uma vez que uma única área poderia ser utilizada como compensação para mais um lote irregular; sendo que essa posição não havia sido consensuada de forma participativa pelos comitês, ou seja, ocorreu a exclusão dos comitês de bacia na elaboração da proposta. ${ }^{18}$

O que os comitês defendiam era que fosse priorizada a aprovação das Leis Específicas da Billings e Guarapiranga, que tratam não apenas da regularização dos empreendimentos irregulares, mas também determinam normas para o ordenamento territorial das bacias, para a compensação ambiental e para a recuperação de áreas degradadas, além de estabelecerem um modelo de gestão compartilhada de recursos hídricos com novos parâmetros para o uso da água.

Diante desse fato, a união dos municípios com a sociedade civil foi fortalecida, a fim de impedir que o trabalho até então realizado fosse perdido. No entanto, isso gerou morosidade no

\footnotetext{
${ }^{18}$ Essas informações foram obtidas nas atas do SCBH-CG.
} 
processo de aprovação, uma vez que demandou mais debates e articulações para se garantir em lei a proteção da bacia da Guarapiranga.

Quanto às negociações para a elaboração da Lei Específica, inicialmente ocorreram dentro de cada segmento do SCBH-CG, e a seguir entre os segmentos do SCBH-CG. Posteriormente entre o SCBH-CG e o CBH-AT, no CERH e no CONSEMA. Em todas as etapas, o texto foi debatido e revisado, até ser encaminhado em 29 de fevereiro de 2004 o Projeto de Lei (PL) para aprovação na Assembleia Legislativa do Estado de São Paulo (ALESP). Nessa fase ocorreu um intenso processo para identificar e analisar os interesses e posições dos membros da ALESP.

Na ALESP, o PL passou por várias comissões e em agosto de 2004 a Comisão de Justiça solicitou complementações ao texto do PL. Em 2005 foram realizadas três audiências públicas para a apresentação e discussão da proposta de lei. O mecanismo de audiência pública é um dos instrumentos de promoção da participação popular nos municípios. Consiste numa sessão de discussão aberta a toda a população para tratar de qualquer tema de importância para o município, tanto para coleta de opinião no momento de formulação de uma política pública quanto para debate em uma tomada de decisão ${ }^{19}$ (INSTITUTO POLIS, 2009).

A primeira audiência pública ocorreu em 14/09/2005 no município de São Paulo, a segunda em 28/09/05 em Itapecerica da Serra e a terceira em 05/10/05 na ALESP, e em 21 de dezembro de 2005 foi aprovada a Lei na ALESP, sendo sancionada em 16 de janeiro de 2006 pelo Poder Executivo.

Após essa fase houve intensa pressão da sociedade civil e demais membros do SCBHCG na ALESP até a aprovação da regulamentação da Lei Específica em março/2007 pelo Decreto n. ${ }^{\circ} 51.686$ (SÃO PAULO, 2007).

Com relação à participação dos segmentos envolvidos, o papel indutor do processo no SCBH-CG é particularmente da Câmara Técnica de Planejamento e Gestão (CTPG). Segundo diversos depoimentos, o papel das prefeituras e das entidades da sociedade civil foi mais ativo, pois a participação dos representantes dos moradores decorre de um histórico de mobilização e reivindicações naquela região antes mesmo da criação do Subcomitê, devido às atividades realizadas pelo Programa Guarapiranga.

\footnotetext{
${ }^{19}$ As audiências públicas estão previstas pela Constituição Federal, Leis Federais e Leis Orgânicas.
} 


\subsubsection{ORGANIZAÇÃO E DINÂMICA DOS ATORES ENVOLVIDOS}

A participação dos representantes do segmento Estado ocorreu em menor proporção com relação aos demais atores envolvidos, chegando até a se distanciar das discussões por certo período. A participação dos representantes da sociedade civil foi ampla, pois, como já dito anteriormente, os moradores há alguns anos já participavam de discussões, devido às atividades realizadas pelo Programa Guarapiranga (1992-2000) em torno de focos temáticos de suas necessidades para a busca de estratégias de solução.

Para a preparação da Lei foram necessárias diversas atividades, tais como encontros temáticos com técnicos da Prefeitura de São Paulo para esclarecimentos, com base nos estudos de viabilidade que foram realizados. Foi instituído um grupo de trabalho na Câmara Técnica de Planejamento e Gestão, no CBH-AT, sob coordenação da Prefeitura de São Paulo, para subsidiar o processo de negociação ocorrido nas plenárias do SCBH-CG, a fim de elaborar um projeto de lei que contemplasse ambas as partes. Para tanto foram realizadas várias reuniões com os diversos atores da bacia; seminários e palestras na região da bacia, além de oficinas nas escolas.

Esse conjunto de atividades visava avançar no processo de negociações entre os setores público, privado e sociedade civil, com o intuito de criar condições para formular uma política de proteção e recuperação do manancial Guarapiranga contemplando os diversos interesses envolvidos.

As dificuldades foram muitas, devido à complexidade dos problemas da região e diversidade de interesses. Essas dificuldades serão apresentadas no item a seguir, bem como o processo de negociação para alcançar a aprovação e regulamentação da referida Lei.

\subsubsection{PROBLEMAS, CONFLITOS E NEGOCIAÇÕES}

A participação na gestão pública é um processo que propicia meios de influenciar a dinâmica de funcionamento do bem público; entretanto, isso é resultado da luta pela conquista de espaços para aumentar a participação social, que é um desafio para alcançar a democracia 
nas relações entre o nível local de governo e a cidadania. Esse processo tem por referência o diálogo e a cooperação que permitem desenvolver iniciativas inovadoras de ampliação da cidadania (JACOBI, 2000).

A seguir são apresentados os problemas e os conflitos resultantes dos embates entre os diferentes atores sociais no desafio de buscar a melhor definição, na forma da Lei, para enfrentar a complexidade da região da bacia hidrográfica da Guarapiranga. Também se analisa o processo de negociação para a aprovação da Lei e do Decreto para sua regulamentação (Decreto n. $\left.{ }^{\circ} 51.686 / 07\right)$.

Os problemas podem assim serem agrupados ${ }^{20}$ :

1. Divergências quanto à competência dos órgãos públicos, estadual e municipal, para a gestão integrada e participativa de recursos hídricos. Ou seja, ausência de definições claras quanto às responsabilidades no processo de gestão, fiscalização e licenciamento;

2. Desconhecimento da legislação ambiental entre os próprios representantes do Poder Público, como ocorreu na ALESP. Isso gerou vários conflitos, pois as propostas contrariavam a legislação hídrica estadual vigente ou então sobrepunham as demais legislações ambientais existentes;

3. Inviabilidade de execução devido às restrições jurídicas, técnicas e financeiras;

4. Falta de confiança entre os atores em negociação;

5. Retirada da arena de negociação, por parte de alguns atores, por serem contrários ao que estava sendo proposto, fazendo movimento isolado e contraditório ao processo de aprovação da Lei;

6. Postura centralizadora, contrariando os avanços democráticos do país, pois havia propostas que não tinham transparência do processo de tomada de decisão, favorecendo a corrupção;

7. Falta de visão a longo prazo e a não integração das políticas de saneamento, habitação, desenvolvimento ambiental com os aspectos sociais. Isto é, inexistência de ações integradas e articuladas;

8. Descontinuidade administrativa, pois ao mudar a gestão pública as prioridades eram outras, ocorrendo assim gestões com avanços e outras não, o que representa a

\footnotetext{
${ }^{20}$ Dados obtidos por meio das entrevistas realizadas pela autora.
} 
morosidade do Poder Público, além da mudança no discurso dos representantes políticos quando ocupam o poder;

9. Desnivelamento do conhecimento a respeito da temática e dificuldades na compreensão da linguagem utilizada entre os atores envolvidos nas discussões.

Diante desses problemas, os conflitos surgiram e as negociações se tornaram difíceis, principalmente em relação às diferenças entre a argumentação técnica e a necessidade de tornar compreensível para os leigos os argumentos que embasavam as propostas; o que representa na prática o que Giddens (1992) denomina de conflito entre conhecimento perito e conhecimento leigo, que se resume principalmente a dificuldades na comunicação.

Nesse sentido, frequentemente os debates assumiam um conteúdo muito técnico, o que dificultava a compreensão por parte dos participantes da sociedade civil, notadamente dos representantes de organizações comunitárias e dos movimentos sociais. Este se constituiu em um fator que provocou tensões e demandou mais informação para garantir a concretização de uma agenda de debates democraticamente estabelecida. Assim, o grande desafio é o de decodificar para o público mais amplo a linguagem técnica que dá o embasamento aos documentos oficiais.

Os conflitos permearam todas as fases de elaboração da Lei, tanto entre os membros do segmento da sociedade civil como entre os próprios técnicos do Estado. A leitura das atas do período (1999-2006) indica que a substituição dos representantes, quando da conclusão de mandato, traz à tona aspectos associados com a desinformação dos novos membros, e, em muitos casos, o menor envolvimento e interesse.

Outro conflito se deu na questão política partidária que compunha a Assembleia Legislativa, uma vez que os interesses divergentes postergaram o consenso para aprovação da Lei, o que demandou forte atuação da sociedade civil para pressionar os representantes que compunham aquela Casa para aprovação da Lei. Mas esse processo de conflitos é visto pelos entrevistados de forma positiva, porque esta foi a forma mais democrática para a obtenção dessa Lei. Este é o avanço, ter a sociedade civil participando e atenta quanto à atuação de seus representantes no poder. O processo de elaboração da Lei Específica foi uma faculdade para todos os participantes, devido ao grau de envolvimento e às centenas de reuniões que ocorreram. 
Frente a esse panorama, outra questão que cabe mencionar é a relação do SCBH-AT com o SCBH-CG, na medida em que a bacia do Alto Tietê apresenta alto grau de complexidade, está estressada fisicamente e concentra o poderio econômico da região. Logo, a divergência de interesses está instalada e a relação do comitê com os subcomitês não vem ocorrendo de forma integrada, em decorrência dos momentos de alta e de baixa dos consensos de gestão na bacia. Outra questão que deve ser ponderada, no que tange aos conflitos, é que nessa região há atores de peso muito distintos, há alguns de grande porte e há outros atores de menor peso, principalmente no segmento sociedade civil.

Outro problema refere-se à desatualização do sistema de informação SIRGH, pois este é um instrumento oficial do sistema de gestão que não está funcionando, levando os membros do Subcomitê a buscar uma estratégia: a criação de e-grupo em site de domínio gratuito a fim de viabilizar a circulação das informações.

A demora em regulamentar a Lei é decorrente do seu novo formato que implicou em uma série de adequações, inclusive no sistema de meio ambiente; sendo que nesse processo de mudança uma série de decisões, como, por exemplo, de quem faz o quê e de que maneira, precisou ser tomada antes mesmo que houvesse a adequação do sistema de meio ambiente. Essa morosidade levou à perda de novos investimentos na região, como o caso da instalação de novas empresas.

Quanto à elaboração do Decreto de regulamentação da Lei Específica, a dinâmica adotada foi a criação de GT por parte do Estado, o qual interrompeu os trabalhos do GT do SCBH-CG para que este pudesse também elaborar a minuta do Decreto. Essa duplicidade de GTs levou ao surgimento de questionamentos por parte da sociedade civil que havia elaborado proposta de minuta do Decreto. Diante dessa situação, a sociedade civil realizou várias discussões que expressavam o seu descontentamento em saber que uma minuta do Decreto estava para ser assinada pelo governador; sendo que demais membros do SCBH-CG desconheciam o teor dessa minuta. Nessa ocasião estava sendo proposto que o Estado ficasse responsável pelo licenciamento e que este não seria feito de forma compartilhada com municípios, além de não haver o conhecimento da sociedade civil. Esse processo ocorreu em fase de transição de governo e gerou insatisfação devido ao não democratismo na gestão das águas.

Essas divergências decorreram da não compreensão sobre o que era de competência de cada órgão do Estado e dos municípios, gerando conflitos para a operacionalização da aprovação do Decreto que regulamenta a Lei Específica. Vale destacar que o processo para a 
concretização de uma lei é complicado por haver a interação de diversos órgãos, e cada órgão técnico mencionado ter de fazer uma instrução do processo com o olhar técnico do respectivo órgão jurídico, o que gera a morosidade do processo e a não regulamentação em cento e vinte dias após aprovação da Lei.

Para acelerar o processo houve pressão por parte dos prefeitos e vereadores junto à Assembleia Legislativa, através dos líderes das bancadas, com participação da sociedade civil; sendo que as principais questões que contribuíram para tal demora foram principalmente: a relação entre regularização e saneamento ambiental; e como calcular a compensação ambiental, articulada com as cargas médias de redução de poluentes, aplicando-se a fórmula constante da lei e utilizando os parâmetros urbanísticos definidos para cada área do município e coleta de informações e monitoramento.

\subsubsection{RESULTADOS ALCANÇADOS}

Todos os entrevistados concordaram que a Lei aprovada consolida as propostas e os interesses dos três segmentos que compõem o SCBH-CG, pois foram incorporadas as emendas apresentadas quando de sua aprovação, mesmo após grandes polêmicas.

O desafio agora é a sua implementação, que primeiramente precisa de ampla divulgação, o que não vem ocorrendo por parte do Estado. Há também a necessidade de funcionamento da agência de bacia, a compatibilidade dos planos diretores com a Lei Específica e com os planos de saneamento, que ainda são desafiadores, além da dotação orçamentária aos municípios para fazer acontecer a recuperação prevista na Lei.

Para acompanhar o processo de implementação da Lei, foi criado um Grupo de Trabalho com essa finalidade, no âmbito do CBH-AT, que identifica como dificuldades para a implementação da Lei a falta de corpo técnico, de recurso financeiro e de divulgação maciça após aprovação da mesma. 
Com relação ao segmento da sociedade civil, para acompanhar o monitoramento da pósaprovação da Lei Específica, o Instituto Socioambiental (ISA) ${ }^{21}$ realizou durante três anos consecutivos o placar Guarapiranga, com informações das instituições da bacia para saber quem está fazendo o que para recuperar o manancial. Esse placar foi realizado por ocasião do Abraço na Guarapiranga, iniciativa proposta pelo ISA, que desde 2006 vem realizando essa atividade. O Abraço na Guarapiranga é um momento importante para a população de São Paulo expressar seu carinho com a centenária represa, protestar contra a situação de degradação do manancial e pressionar por mudanças que garantam a preservação das fontes de água da cidade.

Com base nas informações recebidas, o ISA concluiu que as ações pós-aprovação da Lei Específica ainda são tímidas, mas houve aumento do processo de prestação de contas das instituições à sociedade e alguns outros avanços; como os que se seguem (ISA, 2008c):

- AÇões Para divulgaÇão da lei eSPecífica da GUARAPIRANGa: os municípios deram início a ações de divulgação da Lei, mas ainda não vem ocorrendo de forma a atingir toda a população, apesar da lei determinar que o SCBH-CG, a Agência de Bacia do Alto Tietê, os municípios e a Secretaria Estadual de Meio Ambiente façam ampla campanha para tal;

- FiscalizaÇão E ATUAÇÃo INTEGRAda NA ÁREA dE MANANCiAIS: as ações vêm sendo realizadas em parcerias entre prefeituras e Secretaria de Meio Ambiente do Estado, em especial com a Prefeitura de São Paulo;

- LANÇAMENTO DE ESGOTOS NA REPRESA: boa parte da população residente nos mananciais não conta com coleta e principalmente com tratamento de esgoto, embora haja construções de novos coletores para retirada dos esgotos. Outra ação em andamento na região da Guarapiranga é a Operação Córrego Limpo, parceria entre SABESP e Prefeitura de São Paulo. É importante ressaltar que as ações em curso ainda são tímidas e insuficientes para a reversão dos problemas causados pela ausência de saneamento básico nas moradias da região;

- IMPACTOS Do RodOANEL: o trecho sul do Rodoanel está sendo construído na região dos mananciais e corta boa parte da bacia da Guarapiranga, passando por cima da represa e da várzea de um dos seus principais afluentes, o Rio Embu-Mirim.

${ }^{21}$ O Instituto Socioambiental, Organização não governamental criada em 1994, desenvolveu trabalhos com mananciais na RMSP entre 1996 e 2009, e participou ativamente dos debates que definiram a Lei Específica no âmbito do SCBH-CG (ISA, 2008a). 
Para minimizar os impactos estão sendo realizadas ações, tais como a criação de parques;

- AMPliç̧̃̃o de PARQUeS NA REGião: a ampliação dos parques para a proteção efetiva dessas áreas é uma das principais ações recomendadas no Seminário Guarapiranga 2006. Foi anunciada pela Prefeitura de São Paulo a criação de 3 parques na orla da Guarapiranga.

Quanto ao processo de elaboração da Lei, pode-se afirmar que foi moroso em virtude da falta de dados para subsidiar tecnicamente a proposta. As propostas buscaram incluir nos termos da lei questões consideradas polêmicas, tais como, a fiscalização e o licenciamento sob a responsabilidade do Estado e dos municípios de forma compartilhada.

Os debates provocaram uma dilatação do tempo devido à complexidade dos problemas da região e ao não entendimento de aspectos da proposta que estavam embasados em argumentação técnica que dificultava o entendimento, além de diferenças quanto à concepção da Lei.

O desafio que se colocava para os setores mais mobilizados da sociedade civil era o de garantir uma legislação que contemplasse o planejamento participativo para a bacia e não apenas de comando e controle, como a legislação da década de 70.

Outro fator agregado à morosidade foi a proposta do PL 85 que propunha a regularização dos imóveis localizados em áreas de mananciais sem planejamento ambiental, o que conflitava com o projeto da Lei Específica que propunha não apenas a regularização dos imóveis, mas também as normas para o ordenamento territorial da bacia, com compensação ambiental e gestão compartilhada de recursos hídricos. Logo, o objetivo dos representantes da sociedade civil era o de garantir que suas demandas fossem incorporadas na proposta que redefine a lógica de gestão compartilhada da água.

Mas é importante sempre ter em mente a questão do tempo para agilizar o processo de implementação da Lei, pois enquanto isso não acontece o manancial continua sendo degradado diariamente. Pode-se assim afirmar que todo o processo de discussão teve seu caráter pedagógico muito favorável ao aprendizado democrático que o SCBH-CG tem proporcionado aos atores da bacia. Segundo diversos entrevistados, a dinâmica realizada foi uma experiência de aprendizagem social para o processo de garantia de água em quantidade e qualidade à atual e às futuras gerações. 
Nesse cenário, é preciso considerar que participação é um aspecto essencial a uma lógica de gestão compartilhada, faz parte do processo de desenvolvimento da consciência crítica, propicia a corresponsabilidade no sucesso ou no fracasso, tornando-se assim um processo que se aprende e se aperfeiçoa para um agir conjunto. Para tanto, é preciso criar e organizar os fluxos de comunicação, respeitar as diferenças individuais na forma de participar, estabelecer cooperação graças à confiança estabelecida, a fim de resolver os conflitos gerados.

Um componente importante para o processo de aprendizagem social foi o histórico participativo na região da Guarapiranga, pois contribuiu para a relação entre os diferentes atores sociais, mesmo diante dos diferentes níveis de conhecimento entre estes. Nesse sentido, o diálogo conceitual com o Projeto HarmoniCOP (RIDDER; MOSTERT; WOLTERS, 2005) tem sido um importante referencial para analisar os alcances e limites do processo na bacia da Guarapiranga.

Outro fator é a representação dos diversos setores em cada segmento, Estado, municípios e sociedade civil, que compõem o SCBH-CG. Essa formação contribui para que os diversos interesses da bacia estejam presentes na arena de negociação, que visa à sustentabilidade hídrica da região, mesmo ciente dos desafios para o processo de elaboração dos acordos contemplando a diversidade em debate. Portanto, esse diálogo técnico-social é fundamental para que a gestão democrática inclua os diversos atores sociais na recuperação dos mananciais.

O que foi observado no Subcomitê em questão é que as instituições da sociedade civil têm buscado, em grupo, alternativas para dinamizar a gestão compartilhada de recursos hídricos, dialogando sobre a necessidade de proteção e recuperação dos mananciais da região. E quanto ao Poder público, Estado e municípios, estes estão no exercício para melhorias do processo democrático participativo brasileiro. 


\section{ConsideraÇões Finais: A APRENDIZAGEM Social E SUA CONTRIBUiÇÃo PARA A GOVERNANÇA dA ÁGUA}

Este capítulo está focado na análise dos fatores para a governança da água, com base nos aspectos conceituais apresentados por Rogers e Hall (2003) e UNESCO (2006). Recapitulando os fatores: abertura, comunicação, integração, equidade, accountability, eficiência e sustentabilidade. Esses fatores são fundamentais para a garantia de um processo de governança que demande o máximo de horizontalidade no processo de tomada de decisão, e também a utilização de uma linguagem acessível a todo o público. Dessa forma se amplia a possibilidade de acordos e a participação dos diferentes atores da bacia na lógica de gestão compartilhada.

Além disto, diante da complexidade das questões hídricas, são demandadas políticas e ações coerentes e integradas, para que a governança da água integre os diferentes usos e a interconectividade de seus impactos. Essa integração pressupõe clareza dos papéis dos atores envolvidos, bem como a corresponsabilidade para o êxito das políticas públicas.

Esses fatores serão conjuntamente analisados com os aspectos fundamentais da aprendizagem social, como apresentados por Pahl-Wostl e Hare (2004: 3), que é a consciência de que os objetivos e as perspectivas são diferentes entre os membros do grupo de negociação, que aqui é o SCBH-CG e demais atores envolvidos na elaboração da Lei Específica da Guarapiranga.

Cabe, portanto, identificar o problema que afeta a todos os atores envolvidos e que demanda negociação para ser resolvido. Para tanto, se coloca o desafio de buscar a compreensão da interdependência dos atores e da complexidade do sistema de gestão hídrica compartilhada. No entanto, é preciso confiança, cooperação e corresponsabilidade na implementação dos acordos. O fundamental é a possibilidade de aprender a trabalhar em conjunto, com participação de todos em diálogo constante, ou seja, juntos aprender para juntos intervir. Afinal, a aprendizagem social é um envolvimento que depende da lógica participativa. A frase do Projeto HarmoniCOP (RIDDER; MOSTERT; WOLTERS, 2005), “Aprender Juntos para Administrar Juntos" é emblemática do desafio conceitual e operacional que se coloca para os atores da bacia.

Segundo Solanes e Jouravlev (2006), a efetividade da governança ocorre pela visão agregadora e pela ampliação dos horizontes que inserem novos tomadores de decisão na lógica 
da participação e nas negociações institucionais. É fruto do amadurecimento social, tendo em sua arena de negociações atores envolvidos com o processo de gestão compartilhada, pois é fundamental o envolvimento de todos os atores para a efetiva governança, a fim de que se tenha uma nova cultura da água; a qual é propiciada pela gestão por bacias hidrográficas, onde ocorre a aproximação dos atores locais para a construção coletiva de melhorias na bacia.

Para Gondolo (1996: 29), "as regulamentações criadas para garantir a proteção da área, enquanto manancial e as tecnologias desenvolvidas para controlar a poluição, são insuficientes para atingir tal fim”. Nesse sentido, faz-se necessário desenvolver formas de atuação integradas no enfrentamento de problemas específicos relativos ao desrespeito à lei, ou seja, um trabalho interinstitucional.

A autora conclui ainda que diversos condicionantes interferem na recuperação do manancial, tais como a falta de continuidade das políticas; divergência de interesses entre esferas do governo, gerando conflitos entre Estado e prefeituras; e estrutura segmentada e corporativa de diversos órgãos mais preocupados em deter o poder do que em buscar soluções, o que cria dificuldades na busca de acordos para viabilizar políticas e ações que visem à recuperação do manancial, pois a divergência entre os técnicos dificulta a interação entre os órgãos (GONDOLO, 1996).

A experiência da elaboração da Lei Específica da Guarapiranga mostrou a complexidade inerente a um processo de gestão compartilhada de recursos hídricos. Em muitos momentos, segundo os entrevistados, era evidente a dificuldade dos segmentos em trabalhar de maneira integrada e coesa, o que repercutiu nos conflitos que emergiram e que dificultaram um trabalho mais ágil e a definição de acordos, tanto no plano técnico quanto político. Por exemplo, o embate referente ao licenciamento e fiscalização, e a adequação dos municípios à nova legislação, que foi acordado em ser realizada de forma integrada e compartilhada entre Estado e municípios, por meio de convênios, sem prejuízo de suas atribuições. Caberá ao Estado as intervenções de maior impacto e aos municípios as intervenções de menor porte ${ }^{22}$, ficando assim estabelecida a responsabilidade compartilhada para tal funcionamento.

\footnotetext{
${ }^{22}$ Artigo 15 do Decreto n. ${ }^{\text { }} 51.686$ de 22/03/2007, inciso V: “os empreendimentos de porte significativo: 1. $10.000 \mathrm{~m}^{2}$ (dez mil metros quadrados) de área construída ou mais, para uso não-residencial; 2. 20.000 $\mathrm{m}^{2}$ (vinte mil metros quadrados) de área construída ou mais, para uso residencial; 3. movimentação de terra em área superior a $10.000 \mathrm{~m}^{2}$. E o Artigo 16, poderão ser licenciadas pelos Municípios sem a participação do Estado: II empreendimentos para uso não-residencial de até $10.000 \mathrm{~m}^{2}$ (dez mil metros quadrados) de área construída; III empreendimentos para uso residencial de até $20.000 \mathrm{~m}^{2}$ (vinte mil metros quadrados) de área construída; IV movimentação de terra em área até $10.000 \mathrm{~m}^{2}$ (dez mil metros quadrados)." (SÃO PAULO, 2007).
} 
A experiência mostrou também que é preciso ser flexível para trabalhar com a diversidade de atores e de interesses. Em todo o processo de elaboração da Lei ocorreu, após muitas discussões, uma lógica de cooperação para buscar os acordos, principalmente ao que se refere à definição de papéis entre a administração pública, estadual e municipal, bem como ao que cabe à sociedade civil no exercício de sua cidadania ativa. Esse contexto demonstrou que o processo de aprendizado está se aprimorando com as lições apreendidas, o que evidencia a busca pela maturidade política dos atores envolvidos, tanto do setor público quanto da sociedade civil.

Com base nos relatos obtidos, pode-se concluir que a negociação e a mediação de conflitos na gestão das águas em áreas urbanas, como a RMSP, é um processo dinâmico social, que envolve questões políticas e econômicas para o alcance do desenvolvimento hídrico sustentável com integração de políticas públicas.

Ao negociar, faz-se necessário considerar os aspectos culturais das partes envolvidas, no caso apresentado, com destaque para a nova cultura de democracia participativa conquistada a partir da década de 80. Essa mudança de regime significou um novo modelo de gestão das águas, a qual passou a ser de forma planejada com participação social e gestão descentralizada. Mas sua concretude é um processo longo, pois, como afirma Abers (2007: 1460), "descentralização democrática não pode ser decretada, ela deve ser construída".

Nesse sentido, é fundamental ter clareza das metas a serem alcançadas, das estratégias e a serem utilizadas, a fim de administrar os conflitos e alcançar acordos que incorporem o interesse de todas as partes envolvidas, ou seja, constituir consensos para a governança da água.

Segundo Leach e Pelkey (2001), o consenso estabelecido com a participação das partes envolvidas aumenta a probabilidade de sucesso em sua implementação, por possibilitar que os interesses dos atores diversos sejam discutidos antes da tomada de decisões e que os acordos sejam consensuados entre todos os seus gestores.

Embora seja um processo demorado, por demandar a compreensão da interdependência dos atores no trabalho em conjunto, espera-se que sejam multiplicadas as iniciativas de gestão que contemplem a democracia participativa, a complexidade ambiental e a cidadania ativa para a governabilidade e o fortalecimento do espaço público na formulação de políticas, contemplando as práticas participativas inovadoras.

Para isso, é preciso que as informações sejam socializadas e o conhecimento nivelado, a fim de que o processo de tomada de decisão ocorra de forma igualitária. Essa dinâmica foi 
identificada no SCBH-CG, com as atividades desenvolvidas no período de oito anos, como anteriormente apresentadas, que expressaram o desafio de serem concretizados os fatores da governança da água.

Assim sendo, pode-se dizer que, nesse cenário, houve aprendizagem social com as interações entre os atores envolvidos, principalmente porque ela ocorre com as avaliações sobre o processo de negociação realizado, propiciando aos atores o que Maarleveld e Dangbégnon (1999) denominam de aprendendo a aprender. Ou seja, a democracia participativa na governança das águas é um processo de aprendizagem social que vem sendo aperfeiçoado gradativamente.

Esta pesquisa teve por objetivo analisar o processo e os mecanismos participativos no SCBH-CG para a aprovação da Lei Específica. Os resultados obtidos mostram que, embora este fosse marcado por diversos momentos de tensão, conflitos, indefinições institucionais e morosidade, representaram um significativo avanço na consolidação do sistema integrado de recursos hídricos. Cabe observar também que, apesar de os resultados poderem ainda parecer bastante modestos face aos desafios existentes, estes representam um importante avanço em termos dos seus alcances para o fortalecimento de uma gestão democrática e compartilhada.

Enfim, este estudo teve o propósito de chamar a atenção para os desafios que estão colocados para atenuar a perspectiva de insustentabilidade hídrica na Região Metropolitana de São Paulo, enfatizando dois temas que se tornam essenciais para a agenda das políticas públicas sobre a água: a governança e o processo de aprendizagem social. O que se observou ao longo da pesquisa é que, quando os atores envolvidos estão abertos ao "aprender juntos para administrar juntos” (RIDDER; MOSTERT; WOLTERS, 2005), todos ganham.

No entanto, será necessário dar continuidade a este tipo de investigação, considerando a sua importância e, notadamente, suas complexidades, haja vista tratar-se de mudança de sistema de gestão pública em processo democrático. Cabe também ressaltar o desafio da gestão pública de estar aberta à implementação de práticas que enfatizem processos de aprendizagem social e que mobilizem os atores sociais diferenciados, tanto nos seus interesses quanto nos seus objetivos, a buscar repostas conjuntas para reduzir o impacto da degradação das fontes hídricas e garantir água em quantidade e qualidade de forma continuada, assim como estimular a corresponsabilização na sua governança. 


\section{REFERÊNCIAS}

ABERS, Rebecca Neaera. Building collaboration in Brazilian river basins. Journal World Development, v. 35, n. 8, p. 1450-1463, 2007.

ARAUJO, Maria Celina Soares D. Capital social. Rio de Janeiro: Jorge Zahar, 2003.

BARBANTI JUNIOR, Olympio. Conflitos socioambientais: teorias e práticas. In: Encontro da Associação Nacional de Pesquisa e Pós-Graduaçao em Ambiente e Sociedade - ANPPAS, 1., 2002, Indaiatuda. Anais... Indaiatuba: ANPPAS, 2002.

BOBBIO, Norberto. Estado, governo, sociedade: por uma teoria geral da política. Rio de Janeiro: Paz e Terra, 1987.

BRAGA, Benedito P. F. et al. Pacto federativo e gestão de águas. Revista Estudos Avançados, v. 22, n. 63, p. 17-42, 2008. Disponível em:

<http://www.scielo.br/pdf/ea/v22n63/v22n63a03.pdf>. Acesso em: 2 jan. 2008.

BRANCO, Samuel Murgel; ROCHA, Aristides Almeida. Poluição, proteção e usos múltiplos de represas. São Paulo: CETESB, 1977.

BRASIL. Lei n. ${ }^{\circ}$ 9.433, de 08 de janeiro de 1997. Institui a Política Nacional de Recursos Hídricos, cria o Sistema Nacional de Gerenciamento de Recursos Hídricos, regulamenta o inciso XIX do art. 21 da Constituição Federal, e altera o art. $1^{\circ}$ da Lei n ${ }^{\circ} 8.001$, de 13 de março de 1990, que modificou a Lei no 7.990, de 28 de dezembro de 1989. Diário Oficial da União, Brasília, 9 jan. 1997. Disponível em:

<http://www6.senado.gov.br/legislacao/ListaPublicacoes.action?id=145411>. Acesso em: 19 set. 2007.

Lei n. ${ }^{\circ}$ 9.984, de 17 de julho de 2000. Dispõe sobre a criação da Agência Nacional de Água - ANA, entidade federal de implementação da Política Nacional de Recursos Hídricos e de coordenação do Sistema Nacional de Gerenciamento de Recursos Hídricos, e dá outras providências. Diário Oficial da União, Brasília, 18 jul. 2000. Disponível em: <http://www6.senado.gov.br/legislacao/ListaPublicacoes.action?id=230136>. Acesso em: 30 jan. 2008.

Constituição da República Federativa do Brasil: 1988. 20. ed. Brasília: Câmara dos Deputados/Coordenação de Publicações, 2003. 
BUSTAMANTE, Rocio; PALACIOS, Paulina. Gobernanza: gobernabilidad y agua en los Andes. [S.1]: NEGOWAT, 2005. (Documento Conceptual de la Línea Temática 2: Proyecto Construyendo la Vision Social del Agua desde los Andes). Disponível em: <http://www.negowat.org/curso/Modulo\%20II/Documentos/Visiones\%20Gobernanza.pdf>. Acesso em: 5 set. 2007.

BRUNNENGRAEBER, Achim et al. Interdisciplinarity in governance research. GARNET, Working Paper n. 08/06, Sept. 2006. Disponível em: <http://www.garneteu.org/fileadmin/documents/working_papers/0806.pdf>. Acesso em: 31 mar. 2009.

CARMO, Roberto Luiz. Urbanização, metropolização e recursos hídricos no Brasil. In: DOWBOR, Ladislau; TAGNIN, Renato Arnaldo. Administrando a água como se fosse importante: gestão ambiental e sustentabilidade. São Paulo: SENAC, 2005.

CASTELLANO, Maria. Relações entre poder público e sociedade na gestão dos recursos hídricos: o caso do Consórcio Intermunicipal das bacias hidrográficas dos Rios Piracicaba, Capivari e Jundiaí. 2007. Tese (Doutorado) - Programa de pós-graduação em Ciência Ambiental, Universidade de São Paulo, São Paulo, 2007.

CASTRO, José Esteban. Water governance in the twentieth-first century. Ambiente e Sociedade, v. 10, n. 2, p. 97-118, 2007.

COMITE-AT (Comitê da Bacia Hidrográfica do Alto Tietê). Desenvolvido pelo Governo do Estado de São Paulo. Disponível em: <http://www.comiteat.sp.gov.br/>. Acesso em: 15 mar. 2008.

CRAPS, Marc. Social learning in river basin management: harmoniCOP WP2 reference document. Leuven, Belgium: K. U. Centre for Organizational and Personal Psychology, 2003.

CUNHA, Fernando Monteiro da. Desempenho institucional na gestão de recursos hídricos: o caso dos subcomitês de bacia hidrográfica Cotia-Guarapiranga e Billings-Tamanduateí na região metropolitana de São Paulo. Dissertação (Mestrado) - Programa de Pós-Graduação em Ciência Ambiental, Universidade de São Paulo, 2004.

DOWBOR, Ladislau. O que é poder local? São Paulo: Brasiliense, 1999. (Coleção Primeiros Passos).

EMPLASA (Empresa Paulista de Planejamento Metropolitano). Indicadores Metropolitanos. São Paulo: EMPLASA, 2009. Disponível em:

<http://www.emplasa.sp.gov.br/portalemplasa/vitrinevirtual/Publicacoes/arquivos/ime/popula cao.pdf $>$. Acesso em: 5 jul. 2008. 
FERNANDES, Antônio Sérgio Araújo. O capital social e a análise institucional e de políticas públicas. RAP, Rio de Janeiro, v. 36, n. 3, p. 375-398, maio/jun. 2002.

FURRIELA, Raquel Biderman. Democracia, cidadania e proteção do meio ambiente. São Paulo: Annablume/FAPESP, 2002.

GIDDENS, Anthony. As conseqüências da modernidade. São Paulo: UNESP, 1992.

GONDOLO, Graciela Cristina Fernández. Bacia do Guarapiranga - Região Metropolitana de São Paulo: desafios de um sistema complexo à gestão ambiental. 1996. Dissertação (Mestrado) - Programa de pós-graduação em Ciência Ambiental, Universidade de São Paulo, São Paulo, 1996.

GUTIÉRREZ, Ricardo A. Comitê Gravataí: gestão participativa da água no Rio Grande do Sul. Lua Nova, São Paulo, v. 69, p. 79-121, 2006.

HALL, Allan. Una gobernabilidad eficaz para el agua: documento base para el diálogo global. Water Patterneship - GWP, abr. 2002.

HOUAISS, Antônio. Dicionário Houaiss da Língua Portuguesa. Rio de Janeiro: Editora Objetiva, 2001.

INSTITUTO POLIS. Desenvolvido pelo Instituto Polis. Disponível em: <http://www.polis.org.br/>. Acesso em: 30 nov. 2009.

ISA (Instituto Socioambiental). Programa mananciais. Disponível em: <http://www.mananciais.org.br/site/>. Acesso em: 21 jul. 2008a.

Mananciais da região metropolitana de São Paulo. Disponível em:

<http://www.socioambiental.org/prg/man.shtm\#guara>. Acesso em: 1 dez. 2008b.

Lei específica da Guarapiranga: contribuições para sua compreensão e implementação. São Paulo: ISA, 2008c. Disponível em:

<http://www.mananciais.org.br/upload_/leiespecificaguarapiranga_isajul08.pdf>. Acesso em: 15 set. 2008.

JACOBI, Pedro Roberto. Políticas sociais e ampliação da cidadania. Rio de Janeiro: Ed. FGV, 2000. 
Gestão participativa de bacias hidrográficas no Brasil e os desafios do fortalecimento de espaços públicos colegiados. In: NOBRE, Marcos; SCHATTAN, Vera (Orgs.). Participação e deliberação. São Paulo: Editora 34, 2004.

Governança dos recursos hídricos no Brasil: realidade, desafios e perspectivas. In: Encontro "Governança Ambiental no Brasil: contexto, realidade, rumos", 2006, Recife. Anais... Recife: Fundação Joaquim Nabuco, 2006.

Governança da água no Brasil. In: RIBEIRO, Wagner Costa (Org.). Governança da água no Brasil: uma visão interdisciplinar. São Paulo: Annablume/FAPESP/CNPq, 2009.

JACOBI, Pedro R.; GRANJA, Sandra Inês B.; FRANCO, Maria Isabel. Aprendizagem social: práticas educativas e participação da sociedade civil como estratégias de aprimoramento para a gestão compartilhada em bacias hidrográficas. São Paulo em Perspectiva, v. 20, n. 2, p. 518, abr./jun. 2006.

KAUFMANN, Daniel; KRAAY, Aart; LOBATÓN, Pablo Zoido. Governance and growth: causality which way? Evidence for the world, in brief. Genebra: Word Bank, 2003.

KOOIMAN et al. Interactive governance and governability: an introduction. The Journal of Transdisciplinary Environmental Studies, v. 7, n. 1, 2008. Disponível em: <www.journaltes.dk/vol_7_no_1/no_2_Jan.pdf>. Acesso em: 10 set. 2007.

LEACH, William D.; PELKEY, Neil W. Making watershed partnerships work: a review of the empirical literature. Journal of Water Resources Planning and Management, p. 378-385, Nov./Dec. 2001.

LEFF, Henrique. Saber ambiental: sustentabilidade, racionalidade, complexidade e poder. Tradução de Lúcia Mathilde Endlich Orth. Petrópolis, RJ: Vozes, 2001.

LITTLE, Paul Elliot. Os conflitos socioambientais: um campo de estudo e de ação política. In: BURSZTYN, Marcel (Org.). A difícil sustentabilidade: política energética e conflitos ambientais. Rio de Janeiro: Garamond, 2001.

MAARLEVELD, Marleen; DANGBÉGNON, Constant. Managing natural resources: a social learning perspective. Journal Agriculture and Human Values, v. 16, p. 267-280, 1999.

MOSTERT, Erik. Public participation and the European water framework directive. Montpellier, France: Cemagref, 2003. (HarmoniCOP project - Harmonising Collaborative Planning). 
ONU (Organização das Nações Unidas). El água: uma responsabilidad compartida. $2^{\circ}$ informe de lãs Naciones Unidas sobre el desarrollo de los recursos hídricos en el mundo. Genebra: ONU/UNESCO, 2006. Disponível em:

<http://unesdoc.unesco.org/images/0014/001444/144409S.pdf>. Acesso em: 30 out. 2008.

PAHL-WOSTL, Claudia; HARE, Matt. Processes of social learning in integrated resources management. Journal of Community \& Applied Social Psychology., n. 14, p. 193-206, 2004. Disponível em: <http://www.usf.uos.de/ pahl/forschung/PahlWostlHareJCASP.pdf>. Acesso em: 15 jan. 2009.

PEREIRA, Dilma Seli Pena. Governabilidade dos recursos hídricos no Brasil: a implementação dos instrumentos de gestão na bacia do Rio Paraíba do Sul. Brasília: Agência Nacional de Água, 2003.

PORTO, Monica Ferreira do Amaral. Recursos hídricos e saneamento na Região Metropolitana de São Paulo: um desafio do tamanho da cidade. Brasília: Banco Mundial, 2003.

PUTNAM, Robert D. Comunidade e democracia: a experiência da Itália moderna. 5. ed. Rio de Janeiro: FGV, 2006.

REDE DAS ÁGUAS. Uma política pública para as águas. Disponível em:

<http://www.rededasaguas.org.br/politica_p/politica_p.html>. Acesso em: 8 nov. 2009.

RIBEIRO, Wagner Costa (Org.). Governança da água no Brasil: uma visão interdisciplinar. São Paulo: Annablume/FAPESP/CNPq, 2009.

RIDDER, D.; MOSTERT, E.; WOLTERS, H. A. (Eds.). Aprender juntos para gestionar juntos: la mejora de la participación publica en la gestión del agua. Leuven, Belgium: Druckhaus Bergmann Osnabrück, 2005. (Projeto HarmoniCOP - Harmonising Collaborative Planning). Disponível em:

<http://www.chcantabrico.es/participacion/PHC/documentos/harmonicop.pdf >. Acesso em: 22 abr. 2008.

ROGERS, Peter; HALL, Alan W. Effective water governance. Global Water Partnership Technical Committee (TEC), n. 7, 2003. Disponível em:

<http://www.gwpforum.org/gwp/library/TEC\%207.pdf>. Acesso em: 8 ago. 2007. 
ROMERO, Marcelo de Andrade; PHILIPPI JUNIOR, Arlindo; BRUNA, Gilda Collet. Panorama ambiental da metrópole de São Paulo. São Paulo: Universidade de São Paulo/Faculdade de Saúde Pública/Faculdade de Arquitetura e Urbanismo/Núcleo de Informações em Saúde Ambiental/Signus, 2004.

SACHS, Ignacy. Caminhos para o desenvolvimento sustentável. Rio de Janeiro: Garamond, 2002.

SANTOS, Boaventura de Sousa; AVRITZER, Leonardo. Para ampliar o cânone democrático. In: SANTOS, Boaventura de Sousa (Org.). Democratizar a democracia: caminhos da democracia participativa. 2. ed. Rio de Janeiro: Civilização Brasileira, 2003.

SÃO PAULO (Estado). Constituição Estadual 1989. Constituição do Estado de São Paulo. Diário Oficial de São Paulo, São Paulo, 6 out. 1989. Disponível em:

<http://www.legislacao.sp.gov.br/dg280202.nsf/a2dc3f553380ee0f83256cfb00501463/46e25 76658b1c52903256d63004f305a?OpenDocument>. Acesso em: 30 jan. 2008.

Lei Estadual n. ${ }^{\text {7.663, de }} 20$ de dezembro de 1991. Institui a Política Estadual de Recursos Hídricos. Diário Oficial de São Paulo, São Paulo, 21 dez. 1991.

Secretaria do Meio Ambiente. Coordenadoria de Planejamento Ambiental. Recursos hídricos: histórico, gestão e planejamento. São Paulo: SMA/CPLEA, 1995.

Subcomitê de Bacia Hidrográfica Cotia-Guarapiranga. Regimento do Subcomitê Cotia/Guarapiranga. São Paulo: SCBH-CG, 1997a. Disponível em: $<$ http://cotiaguarapiranga.info/wp-content/uploads/2009/09/Regimento-doSubcomit\%C3\%AA4.pdf>. Acesso em: 25 jun. 2008.

Lei n. ${ }^{\circ} 9.866$, de 28 de novembro de 1997 . Dispõe sobre diretrizes e normas para a proteção e recuperação das bacias hidrográficas dos mananciais de interesse regional do Estado de São Paulo e dá outras providências. Diário Oficial de São Paulo, São Paulo, 9 dez. 1997b. Disponível em: <http://www.daee.sp.gov.br/legislacao/arquivos/733/lei_9866.pdf>. Acesso em: 30 jun. 2008.

Subcomitê de Bacia Hidrográfica Cotia-Guarapiranga. Deliberação SCBH-ATCG n. ${ }^{\circ}$ 9/98, de 3 de dezembro de 1998. Aprova normas gerais para criação e funcionamento das câmaras técnicas. Diário Oficial de São Paulo, São Paulo, 5 maio 1999. Disponível em: <http://www.ipef.br/legislacao/bdlegislacao/arquivos/2920.rtf>. Acesso em: 25 jun. 2008. 
Secretaria do Meio Ambiente. Coordenadoria de Planejamento Ambiental Estratégico e Educação Ambiental. Gestão participativa das águas. São Paulo: SMA/CPLEA, 2004.

Lei Estadual n. ${ }^{\circ}$ 12.233, de 16 de janeiro de 2006. Define a área de Proteção dos Mananciais da Bacia Hidrográfica do Reservatório Guarapiranga e dá outras providências. Diário Oficial de São Paulo, São Paulo, 17 jan. 2006. Disponível em: <http://homologa.ambiente.sp.gov.br/EA/adm/admarqs/LeiEst_12233.pdf>. Acesso em: 7 ago. 2007.

Decreto n. ${ }^{\circ}$ 51.686, de 22 de março de 2007. Regulamenta dispositivos da Lei estadual $\mathrm{n}^{\circ} 12.233$, de 16 de janeiro de 2006, - Lei Específica Guarapiranga, que define a Área de Proteção e Recuperação dos Mananciais da Bacia Hidrográfica do Guarapiranga APRM-G, e dá providências correlatas. Diário Oficial de São Paulo, São Paulo, 23 mar. 2007. Disponível em:

<http://www.pinheirospirapora.org.br/pp/downloads/legislacao/decreto/DECRETO\%20N\%C 2\%BA\%2051.686\%20-\%2022\%20de\%20mar\%C3\%A7o\%20de\%202007\%20$\% 20$ Regulariza\%20a\%20Lei\%20Espec\%C3\%ADfica\%20da\%20Guarapiranga.pdf $>$. Acesso em: 20 out. 2009.

SETTI, Arnaldo Augusto; LIMA, Jorge Enoch Furquim; CHAVES, Adriana Goretti de Miranda; PEREIRA, Isabella de Castro. Introdução ao gerenciamento de recursos hídricos. 2. ed. Brasília: Agência Nacional de Energia Elétrica/Superintendência de Estudos e Informações Hidrológicas, 2000.

SIGRH (Sistema de Informação Sistema de Informações para o Gerenciamento de Recursos Hídricos do Estado de São Paulo). Desenvolvido pelo Governo do Estado de São Paulo. Disponível em: 〈http://www.sigrh.sp.gov.br〉. Acesso em: 15 mar. 2008.

SILVA, Ricardo Toledo; PORTO, Monica Ferreira do Amaral. Gestão urbana e gestão das águas: caminhos da integração. Revista Estudos Avançados, v. 17, n. 47, 2003.

SOARES, Samira Iasbeck de Oliveira. A mediação de conflitos na gestão de recursos hídricos no Brasil. 2008. Dissertação (Mestrado) - Programa de pós-graduação em Ciência Ambiental, Universidade de São Paulo, São Paulo, 2008.

SOLANES, Miguel; JOURAVLEV, Andrei. Water governance for development and sustainability. Santiago, Chile: CEPAL, 2006. (Serie Recursos Naturales e Infraestrutura).

THEODORO, Suzi Huff. Conflitos e uso sustentável dos recursos naturais. Rio de Janeiro: Garamond, 2002. 
THEYS, Jaques. La gouvernance, entre innovation et impuissance: le cas de l'environnement. Développement Durable \& Territoires: Economie, Geographie, Politique, Droit, Sociologie, 1 nov. 2003. Disponível em: 〈http://developpementdurable.revues.org/document1523.html>. Acesso em: 9 ago. 2007.

TOURAINE, Alan. O que é a democracia? Tradução de Guilherme João de Freitas Teixeira. Petrópolis, RJ: Vozes, 1996.

TUNDISI, José Galizia. Água no século XXI: enfrentando a escassez. São Carlos: IIE Instituto Internacional de Ecologia; São Paulo: Rima, 2003.

UNESCO-WWAP (United Nations Educational, Scientific and Cultural Organization United Nations World Water Assessment Programme). Water a shared responsibility. Report 2. Paris, France: Berghahn Books, 2006.

WHATELY, Marussia; CUNHA, Pillar Machado. Guarapiranga 2005: como e porque São Paulo está perdendo este manancial: resultados do diagnóstico socioambiental participativo da bacia hidrográfica da Guarapiranga. São Paulo: ISA, 2006a.

(Orgs.). Seminário Guarapiranga 2006: proposição de ações prioritárias para garantir água de boa qualidade para abastecimento público. São Paulo: ISA, 2006 b.

WHATELY, Marussia; SANTORO, Paula Freire; TAGNIN, Renato Arnaldo. Contribuições para a elaboração de leis específicas de mananciais: o exemplo da Billings. São Paulo: ISA, 2008. 


\section{Bibliografia Consultada}

ABERS, Rebecca; DINO, Karina Jorge. Descentralização da gestão da água: por que os comitês de bacia estão sendo criados? Revista Ambiente e Sociedade, v. 8, n. 2, jul./dez 2005.

ARAÚJO, Vinícius de Carvalho. A conceituação de governabilidade e governança, da sua relação entre si e com o conjunto da reforma do estado e do seu aparelho. Brasília: ENAP, 2002. (Texto para discussão n. 45).

ARNESTEIN, Sherry R. A ladder of citizen participation. JAIP, v. 35, n. 4, July, 1969.

Disponível em: <http://lithgow-schmidt.dk/sherry-arnstein/ladder-of-citizen-

participation.html>. Acesso em: 20 jun. 2008.

BAQUERO, Marcello (Org.). Capital social, desenvolvimento sustentável e democracia na América Latina. Porto Alegre: UFRGS, 2007.

BARREIRA, Cristina Catunda. Conflitos da expansão urbana na bacia hidrográfica de Guarapiranga: a ocupação urbana e o papel desempenhado pelos instrumentos de planejamento urbano ambiental na configuração do espaço. 2000. Dissertação (Mestrado) Programa de Pós-Graduação em Ciência Ambiental, Universidade de São Paulo, São Paulo, 2000 .

BEDUSCHI FILHO, Luiz Carlos. Participação e aprendizagem social em processos de desenvolvimento territorial rural: evidências de dois estudos de caso no Brasil. Revista Econômica do Nordeste, Fortaleza, v. 38, n. 2, p. 259-275, abr./jun. 2007.

BRAGA, Benedito P. F. The management or urban water conflicts in the metropolitan region of São Paulo. Journal Water International, v. 25, n. 2, p. 167-231, 2000.

DIAS, Claudia. Pesquisa qualitativa: categorias e referências. Disponível em: <http://www.geocities.com/claudiaad/qualitativa.pdf>. Acesso em: 2 fev. 2008.

DUARTE, Rosália. Pesquisa qualitativa: reflexões sobre o trabalho de campo. Cadernos de Pesquisa, n. 115, p. 139-154, mar. 2002. Disponível em: <http://www.scielo.br/pdf/cp/n115/a05n115.pdf>. Acesso em: 3 fev. 2008. 
DUTRA, Dirce de Fátima Cattani. América Latina: governabilidade, governance e desenvolvimento. In: ILASSA27. Student Conference on Latin America, 27., 2007, Austin. Papers... Austin: ILASSA27. Student Conference on Latin America: 2007. Disponível em: <http://lanic.utexas.edu/project/etext/llilas/ilassa/2007/dutra.pdf>.

Acesso em: 10 maio 2009.

FUSP (Fundação Universidade de São Paulo). Plano da bacia do Alto Tietê: relatório final diagnóstico analítico da bacia. São Paulo: FUSP, 2008. 1 v.

HUITEMA, D.; BRESSERS, Hans Th. A. Scaling water governance: the case of the implementation of the European Water Framework Directive in the Netherlands. Synthesis Conference of the Institutional Dimensions of Global Environmental Change program, 2006, Bali, Indonesia. Papers... Bali, Indonesia: CSTM-reeks, 2006.

HUITEMA, D.; GOOCH, G. Improving governance through deliberative democracy: initiating informed public participation in water governance policy processes. In: Stockholm Water Symposium, 2004, Stockholm. Papers... Stockholm: Stockholm Water Symposium, 2004.

JACOBI, Pedro Roberto. Educação ambiental: o desafio da construção de um pensamento crítico, complexo e reflexivo. Revista Educação e Pesquisa, São Paulo, v. 31, n. 2, p. 233250, maio/ago. 2005.

Comitês de bacias hidrográficas: o que está em jogo na gestão compartilhada e participativa. In: DOWBOR, Ladislau; TAGNIN, Renato Arnaldo. Administrando a água como se fosse importante: gestão ambiental e sustentabilidade. São Paulo: SENAC, 2005.

Com quantos atores se faz uma boa governança. Revista Página 22, 22 mar. 2009.

MONTEIRO, Fernando; EDUARTE, Marina; CASTELLANO, Maria;

ROMAGNOLI, Reynaldo; NOVAES, Ricardo. Capital social e desempenho institucional: reflexões teórico-metodológicas sobre estudos no comitê de bacia hidrográfica do Alto Tietê, São Paulo. In: Encontro anual da ANPPAS, 3., 2006, Brasília. Anais... São Paulo: ANNPAS/Annablume, 2006. p. 303-327.

JOHNSSON, Rosa Maria Formiga; LOPES, Paula Duarte (Orgs.). Projeto Marca d'água: seguindo as mudanças na gestão das bacias hidrográficas do Brasil. Brasília: Finatec, 2003.

KAUFMANN, Daniel et al. Governance matters. Genebra: World Bank, 1999. (Policy Research Working paper 2196). 
KUBRUSLY, Violeta Saldanha. Gestão socioambiental urbana e o geoprocessamento como apoio estratégico para análise do território: o caso da bacia hidrográfica do Guarapiranga. 2000. Tese (Doutorado) - Faculdade de Filosofia, Letras e Ciências Humanas, Universidade de São Paulo, São Paulo, 2000.

MAYNTZ, Renate. Nuevos desafíos de la teoría de governance. Instituciones y Desarrollo, Barcelona, España, n. 7, p. 35-51, 2000.

MEDALYE, Jacqueline; Jim Kundell. Water governance. In: CLEVELAND, Cutler J. (Ed.). Encyclopedia of earth. Washington, D.C.: Environmental Information Coalition/National Council for Science and the Environment, 2008. Disponível em:

<http://www.eoearth.org/article/Water_governance>. Acesso em: 25 jun. 2008.

MOLLE, F.; WESTER, P.; HIRSCH, P. River basin development and management. In: MOLDEN, David (Ed.). Water for food. Water for life. Wallingford, UK: CABI, 2007.

MONTEIRO, Fernando da Cunha. Para além da participação: aprendizagem social na gestão dos recursos hídricos. 2009. Tese (Doutorado) - Programa de Pós-Graduação em Ciência Ambiental, Universidade de São Paulo, São Paulo, 2009.

MORIN, Edgar. Saberes globais e saberes locais: o olhar transdisciplinar. Rio de Janeiro: Garamond, 2000.

MOTA, José Aroudo. Uma agenda pública para a gestão de água: instrumentos institucionais para a governança de recursos hídricos. In: DOWBOR, Ladislau; TAGNIN, Renato Arnaldo. Administrando a água como se fosse importante: gestão ambiental e sustentabilidade. São Paulo: SENAC, 2005.

PAHL-WOSTL, Claudia et al. Managing change toward adaptive water management through social learning. Ecology and Society, v. 12, n. 2, 2007. Disponível em:

<http://www.ecologyandsociety.org/vol12/iss2/art30/>. Acesso em: 30 jun. 2008.

PAHL-WOSTL, Claudia, et al. Social learning and water resources management. Ecology and Society, v. 12, n. 2, 2007. Disponível em:

<http://www.ecologyandsociety.org/vol12/iss2/art5>. Acesso em: 30 jun. 2008.

PEREIRA, Luiz Carlos Bresser. A Reforma do estado dos anos 90: lógica e mecanismos de controle. Brasília: Ministério da Administração Federal e Reforma do Estado, 1997. 1 v. (Cadernos MARE da reforma do estado). 
PEREIRA, Marina Eduarte. Compartilhando a gestão dos recursos hídricos: Joinville e o Rio Cubatão. 2005. Dissertação (Mestrado) - Programa de Pós-Graduação em Ciência Ambiental, Universidade de São Paulo, São Paulo, 2005.

PORTO, Monica Ferreira do Amaral; PORTO, Rubem La Laina. Gestão de bacias hidrográficas. Estudos Avançados, São Paulo, v. 22, n. 63, 2008.

PRETTE, Marcos Estevan Del. Apropriação de recursos hídricos e conflitos sociais: a gestão das áreas proteção aos mananciais da região metropolitana de São Paulo. 2000. Tese

(Doutorado). Faculdade de Filosofia, Letras e Ciências Humanas, Universidade de São Paulo, São Paulo, 2000.

PRUITE, Bettye; TOMAS, Philip. Democratic dialogue: a handbook for practioners. Estocolmo: International IDEA, 2007. Disponível em:

<http://www.democraticdialoguenetwork.org/documents/view.pl?f_id=1322;blank=1;print=1>. Acesso em: 20 out. 2008.

SNEDDON, Chris; HARRIS, Leila; DIMITROV, Radoslav; ÖZESMI, Uygar. Contested waters: conflict, scale, and sustainability in aquatic socioecological systems. Journal Society in Natural Resources, v. 15, p. 663-675, 2002,

SOARES, Samira; TEODORO, Hildelano; JACOBI, Pedro Roberto. Governança e Política Nacional de Recursos Hídricos: qual a posição da gestão das águas no Brasil? In: Encontro Nacional da Associação Nacional de Pós-Graduação e Pesquisa em Ambiente e Sociedade/ANPPAS, 4., 2008, Brasília, 2008. Anais... Brasília: ANPPAS, 2008. <http://www.anppas.org.br/encontro4/cd/gt12.html>. Acesso em: 15 mar. 2009.

SUBCOMITÊ COTIA-GUARAPIRANGA. Relato da Câmara Técnica de Planejamento. São Paulo: 17 set. 2001. Mimeo.

SVENDSEN, Mark; WESTER, Philippus. Managing river basins: Lessons from experience. In: SVENDSEN, Mark (Ed.). Irrigation and river basin management: options for governance and institutions. Wallingford: CABI Publishing, 2005. p. 215-229.

THAME, Antonio Carlos de Mendes (Org.). Comitês de bacias hidrográficas: uma revolução conceitual. São Paulo: IQUAL, 2002.

VERKERK, Maarten Philippus. Global water governance: conceptual design of global institutional arrangements. 2007. Thesis (Master) - MSc degree Water Engineering \& Management, University of Twente, Enshede, The Netherlands, 2007. Disponível em: <http://essay.utwente.nl/57972/1/scriptie_Verkerk.pdf>. Acesso em: 25 abr. 2009. 
WARNER, Jeroen. Multi-stakeholder platforms: more sustainable participation? International Journal on Water Resources Development, 2006.

The world is not flat: the sovereign state and multilevel hydro-hegemony. Wageningen, UK: The London School of Economics and Political Sciense, 2007. Disponível em: <http://www2.1se.ac.uk/geographyAndEnvironment/CEPG/LWRG/Publications/Seminar\%20S eries\%20Winter\%202007/Warner\%20-

\%20World\%20is\%20Not\%20Flat\%20(LWRG\%202007).pdf〉. Acesso em: 10 abr. 2009. 


\title{
ANEXOS
}

\section{ANEXO 1 - ENTREVISTAS SEMIESTRUTURAdAS COM ATORES QUE PARTICIPARAM DA ELABORAÇÃO DA LEI ESPECÍFICA}

\author{
Subcomitê Cotia Guarapiranga \\ Segmentos: Estado, Municípios e Sociedade Civil
}

\section{IDENTIFICAÇÃO}

Data:

Hora: início: término:

Nome do entrevistado:

Fone: e-mail:

Nome da instituição:

Tipo: Estado ( ) Município ( ) Sociedade Civil ( )

Cargo/ Função que ocupa:

Período de participação no Subcomitê Cotia Guarapiranga:

\section{ELABORAÇÃO DA LEI N ${ }^{\circ}$ 12.233/06 APRM-G}

1. Quais segmentos do SCBH-CG realizaram debates com a comunidade no processo de elaboração da lei e como se articularam para tal realização?

2. Houve interesse e participação da comunidade? Você sabe contar como isto ocorreu (estratégias de divulgação do processo, os segmentos mobilizados e os índices de participação)?

3. Quais as principais dificuldades de participação da sociedade civil neste processo?

4. O que poderia ter sido feito para ampliar a participação?

5. Quais atividades sua instituição realizou no período de elaboração da lei que contribuíram para o processo?

\section{CONFLITOS}

6. Quais os principais conflitos no processo de elaboração e de aprovação da Lei Específica da Guarapiranga? 
7. Considerando que decorreram oito anos entre a elaboração e aprovação da lei, como você avalia os avanços e as dificuldades no processo durante as diferentes gestões no Estado e nos Municípios?

8. Como você avalia a relação do SCBH-CG com o CBH-Alto Tietê?

\section{PÓS-APROVAÇÃO}

9. A Lei aprovada consolida as propostas e os interesses dos três segmentos participantes? Quais interesses estão mais representados na redação final da lei?

10. Como está o processo de implementação da lei? (PDPA e outros instrumentos) Quais as dificuldades encontradas?

11. Há algum outro aspecto que você deseja mencionar com relação ao processo de elaboração, aprovação e implementação de Lei Específica?

\section{COMPOSIÇÃO E FUNCIONAMENTO DO SCBH-CG}

12. Como você avalia a composição do SCBH-CG? Você acha que a sociedade civil está suficientemente representada (03 uso doméstico; 02 atividades agrícolas, 02 industriais, 02 comerciais, lazer e pesca; 04 defesa do meio ambiente; 03 entidades técnicas; 01 universidades e institutos de pesquisa; 01 organizações sindicais)?

13. Quais as fontes de recursos financiam as atividades do SCBH-CG?

14. Como é o processo de deliberação sobre o uso dos recursos?

15. Existem conflitos entre os membros do SCBH-CG em relação aos recursos do FEHIDRO?

16. O levantamento inicial indica que as instituições que compõem o SCBH-CG são as mais beneficiadas com os recursos do FEHIDRO, como você avalia isto? (delibera, executa e fiscaliza)

17. O fato do SCBH-CG dispor de tais recursos influência na sua composição? 


\section{Anexo 2 - Membro Titulares e SuPlentes do SCBH-CG (1999-2007)}

\section{Segmento: Estado}

\begin{tabular}{|c|c|c|c|c|}
\hline INSTITUIÇÃO & $\begin{array}{c}\text { 1999-2000 } \\
\text { TITULAR/SUPLENTE }\end{array}$ & $\begin{array}{c}\text { 2001-2002 } \\
\text { TITULAR/SUPLENTE }\end{array}$ & $\begin{array}{c}\text { 2003-2004 } \\
\text { TITULAR/SUPLENTE }\end{array}$ & $\begin{array}{c}\text { 2005-2007 } \\
\text { TitULAR/SUPLENTE }\end{array}$ \\
\hline $\begin{array}{l}\text { DAEE - Depto Águas e Energia } \\
\text { Elétrica }\end{array}$ & $\begin{array}{l}\text { Osmar Luiz Costa/ } \\
\text { Fernando Teodoro de Oliveira }\end{array}$ & $\begin{array}{l}\text { Vera Helena Reis Martins/ } \\
\text { Salvador L Castilho Junior }\end{array}$ & $\begin{array}{l}\text { Osmar Luiz Costa/ } \\
\text { Fernando Teodoro Oliveira }\end{array}$ & $\begin{array}{l}\text { Osmar Luiz Costa/ } \\
\text { Fernando Teodoro Oliveira }\end{array}$ \\
\hline $\begin{array}{l}\text { Secretaria de Agricultura e } \\
\text { Abastecimento }\end{array}$ & $\begin{array}{c}\text { Renato F Vianna Neto/ } \\
\text { Maximiliano Miura }\end{array}$ & José Antonio Teixeira & $\begin{array}{l}\text { Renato Freitas Vianna Neto/ } \\
\text { Sergio Roberto G Santos }\end{array}$ & $\begin{array}{c}\text { Renato Freitas Vianna Neto/ } \\
\text { Celso Glasser }\end{array}$ \\
\hline $\begin{array}{l}\text { Secretaria de Economia e } \\
\text { Planejamento }\end{array}$ & --------- & --------- & $\begin{array}{c}\text { Edvaldo Roberto Coratto/ } \\
\text { Moisés Baum }\end{array}$ & \\
\hline Secretaria de Educação & $\begin{array}{l}\text { Manoel Cardoso de Mendonça/ } \\
\text { Nanci Novo e Trigueiros }\end{array}$ & $\begin{array}{c}\text { Manoel Cardoso de } \\
\text { Mendonça/ } \\
\text { Nanci Novo e Trigueiros }\end{array}$ & $\begin{array}{c}\text { Marilene Franguelli/ } \\
\text { Maria Ap. Ferraz Santos Reis }\end{array}$ & $\begin{array}{c}\text { Maria Ap. Ferraz dos Santos } \\
\text { Reis/ } \\
\text { Levi de Freitas Sthler }\end{array}$ \\
\hline Secretaria de Habitação & $\begin{array}{l}\text { André Garcia Martin/ } \\
\text { Valentina Denizo }\end{array}$ & $\begin{array}{l}\text { André Garcia Martin/ } \\
\text { Valentina Denizo }\end{array}$ & $\begin{array}{c}\text { Maria Claudia Pereira Souza/ } \\
\text { André Garcia Martin }\end{array}$ & $\begin{array}{c}\text { Maria Claudia Pereira Souza/ } \\
\text { André Garcia Martin }\end{array}$ \\
\hline $\begin{array}{l}\text { Secretaria de Recursos Hídricos, } \\
\text { Saneamento e Obras (SABESP) }\end{array}$ & $\begin{array}{c}\text { Amauri Polachi/ } \\
\text { Mariza Guimarães Prota }\end{array}$ & $\begin{array}{c}\text { Pedro Luiz Ibraim Hallack/ } \\
\text { Amauri Polachi }\end{array}$ & $\begin{array}{c}\text { Lineu Andrade Almeida/ } \\
\text { Marisa G. Prota }\end{array}$ & $\begin{array}{c}\text { Mariza Guimarães Prota / } \\
\text { Eliana Kazue I. Kitahara }\end{array}$ \\
\hline $\begin{array}{l}\text { Secretaria de Recursos Hídricos, } \\
\text { Saneamento e Obras }\end{array}$ & $\begin{array}{l}\text { Ricardo Guilherme Araújo/ } \\
\text { Mauricio Lenzi Brandão }\end{array}$ & $\begin{array}{l}\text { Mauricio Lenzi Brandão/ } \\
\text { Ricardo Guilherme Araújo }\end{array}$ & $\begin{array}{l}\text { Ricardo Guilherme Araújo/ } \\
\text { Carla Hilst Menezes }\end{array}$ & $\begin{array}{l}\text { Mauricio Lenzi Brandão/ } \\
\text { Kátia Simões Parente }\end{array}$ \\
\hline Secretaria de Saúde & $\begin{array}{c}\text { Antonio Carlos Nasi/ } \\
\text { Solange Campos }\end{array}$ & $\begin{array}{c}\text { Antonio Carlos Nasi/ } \\
\text { Solange Campos }\end{array}$ & $\begin{array}{l}\text { Margarete Newmann Reis/ } \\
\text { Ubiratan Carvalho Pereira }\end{array}$ & $\begin{array}{l}\text { Margarete Newmann Reis/ } \\
\text { Ubiratan Carvalho Pereira }\end{array}$ \\
\hline Secretaria de Transportes & $\begin{array}{c}\text { Francisca Luiza G Cardieri/ } \\
\text { Marcia Rodrigues }\end{array}$ & $\begin{array}{c}\text { Francisca Luiza G Cardieri/ } \\
\text { Marcia Rodrigues }\end{array}$ & --------- & --------- \\
\hline $\begin{array}{l}\text { Secretaria do Meio Ambiente - } \\
\text { Polícia Florestal e de Mananciais }\end{array}$ & Milton Sossumu Nomura/ & $\begin{array}{c}\text { Glauco Rogério Ribeiro } \\
\text { Alves/ } \\
\text { Dirceu Nunes de Miranda }\end{array}$ & $\begin{array}{l}\text { Rogério Lemos de Toledo/ } \\
\text { Osvaldo Morato Garcia }\end{array}$ & \\
\hline $\begin{array}{l}\text { Secretaria do Meio Ambiente - } \\
\text { CETESB }\end{array}$ & $\begin{array}{l}\text { Paulo Cesar Albuquerque/ } \\
\text { Valeria Mendes Ferreira }\end{array}$ & $\begin{array}{l}\text { Paulo Cesar Albuquerque/ } \\
\text { Valeria Mendes Ferreira }\end{array}$ & $\begin{array}{l}\text { João Antonio Romano/ } \\
\text { Edison Soares da Costa }\end{array}$ & $\begin{array}{l}\text { Benedito Afonso T. Moreira/ } \\
\text { Edison Soares da Costa }\end{array}$ \\
\hline Secretaria do Meio Ambiente & $\begin{array}{c}\text { Dagoberto Meneghini/ } \\
\text { Antonio Carlos de Oliveira }\end{array}$ & $\begin{array}{l}\text { Sonia Liberati/ } \\
\text { Claudia Jorge }\end{array}$ & $\begin{array}{l}\text { Maria Carmem Gomes/ } \\
\text { Carlos Alberto Saito }\end{array}$ & $\begin{array}{l}\text { Márcia Maria Nascimento/ } \\
\text { Paulo Eduardo Barcellos }\end{array}$ \\
\hline
\end{tabular}

FONTE: Elaborado pela autora. 


\section{SEGMENTO: MUNICÍPIOS}

\begin{tabular}{|c|c|c|c|c|}
\hline Instituição & $\begin{array}{c}\text { 1999-2000 } \\
\text { Titular/Suplente }\end{array}$ & $\begin{array}{c}\text { 2001-2002 } \\
\text { Titular/Suplente }\end{array}$ & $\begin{array}{c}\text { 2003-2004 } \\
\text { Titular/Suplente }\end{array}$ & $\begin{array}{c}\text { 2005-2007 } \\
\text { Titular/Suplente }\end{array}$ \\
\hline Prefeitura do Município de Cotia & $\begin{array}{l}\text { Mario Dias Ribeiro/ } \\
\text { Vitor Luiz de M Higuchi }\end{array}$ & $\begin{array}{c}\text { Joaquim Horacio Pedroso } \\
\text { Neto/ } \\
---\end{array}$ & $\begin{array}{l}\text { Joaquim Horacio Pedroso } \\
\text { Neto/ } \\
\text { Teresa B H Costa Maia }\end{array}$ & $\begin{array}{c}\text { Joaquim Horacio Pedroso } \\
\text { Neto/ } \\
---\end{array}$ \\
\hline $\begin{array}{l}\text { Prefeitura da Estância Turística de } \\
\text { Embu das Artes }\end{array}$ & $\begin{array}{c}\text { Oscar Yasbek/ } \\
\text { Gina Rizpah Besen }\end{array}$ & Geraldo Cruz/ & $\begin{array}{c}\text { Geraldo Cruz/ } \\
\text { João Carlos P Ramos }\end{array}$ & $\begin{array}{l}\text { Geraldo Cruz/ } \\
\text { Marilene Mantovani }\end{array}$ \\
\hline $\begin{array}{l}\text { Prefeitura da Cidade de Taboão da } \\
\text { Serra }\end{array}$ & Fernando Fernandes/ & Fernando Fernandes/ & $\begin{array}{c}\text { Fernando Fernandes/ } \\
\text {--- }\end{array}$ & Evilásio Cavalcante Farias/ \\
\hline $\begin{array}{l}\text { Prefeitura do Município de } \\
\text { Itapecerica da Serra }\end{array}$ & $\begin{array}{l}\text { Lacir Ferreira Baldusco/ } \\
\text { Jumara Moraes Bocatto }\end{array}$ & $\begin{array}{l}\text { Lacir Ferreira Baldusco/ } \\
\text { Jumara Moraes Bocatto }\end{array}$ & $\begin{array}{l}\text { Lacir Ferreira Baldusco/ } \\
\text { Jumara Moraes Bocatto }\end{array}$ & Jorge José da Costa/ \\
\hline Prefeitura Municipal de Embu-Guaçu & $\begin{array}{c}\text { Antonio Lopes Soeiro Filho/ } \\
---\end{array}$ & $\begin{array}{c}\text { Valter Antonio Marques/ } \\
\text {--- }\end{array}$ & $\begin{array}{l}\text { Valter Antonio Marques/ } \\
\text { Elisangela Furlan }\end{array}$ & $\begin{array}{l}\text { Valter Antonio Marques/ } \\
\text { Jumara Moraes Bocatto }\end{array}$ \\
\hline Prefeitura municipal de Juquitiba & $\begin{array}{c}\text { Ayres Scorsatto/ } \\
\text { Sergio Gazal }\end{array}$ & $\begin{array}{c}\text { Ayres Scorsatto/ } \\
\text { Rosa Tereza G Oliveira }\end{array}$ & $\begin{array}{c}\text { Ayres Scorsatto/ } \\
\text { Rosa Tereza G Oliveira }\end{array}$ & $\begin{array}{c}\text { Roberto Silva Rocha/ } \\
\text {--- }\end{array}$ \\
\hline $\begin{array}{l}\text { Prefeitura Municipal de São } \\
\text { Lourenço da Serra }\end{array}$ & $\begin{array}{l}\text { Lener do Nascimento Ribeiro/ } \\
\text { Cristina Soares Copa Velazques }\end{array}$ & $\begin{array}{l}\text { Lener do Nascimento Ribeiro/ } \\
\text { Miguel Angel F Vero }\end{array}$ & $\begin{array}{l}\text { Lener do Nascimento Ribeiro/ } \\
\text { Marcio Vinicius Bittencourt }\end{array}$ & $\begin{array}{c}\text { Lener do Nascimento Ribeiro/ } \\
\text { José Merli }\end{array}$ \\
\hline Prefeitura da Cidade de São Paulo & $\begin{array}{c}\text { Renato Mattos Zuccolo/ } \\
\text { Adilson M Claro }\end{array}$ & --------- & --------- & --------- \\
\hline $\begin{array}{l}\text { Prefeitura de São Paulo - Secretaria } \\
\text { da Habitação }\end{array}$ & $\begin{array}{c}\text { Elisabete França/ } \\
\text { Violeta Saldanha Kubrusly }\end{array}$ & $\begin{array}{c}\text { Ana Lucia Ancona/ } \\
\text { Violeta Saldanha Kubrusly }\end{array}$ & $\begin{array}{l}\text { Ana Lucia Ancona/ } \\
\text { Violeta Saldanha Kubrusly }\end{array}$ & $\begin{array}{l}\text { Ana Lucia Ancona/ } \\
\text { Violeta Saldanha Kubrusly }\end{array}$ \\
\hline $\begin{array}{l}\text { Prefeitura de São Paulo - Secretaria } \\
\text { das Administrações Regionais }\end{array}$ & $\begin{array}{c}\text { Valdir Ribeiro Filho/ } \\
\text { Antonio Pascoal Pontieri - Adm. } \\
\text { Capela do Socorro }\end{array}$ & --------- & --------- & --------- \\
\hline $\begin{array}{l}\text { Prefeitura de São Paulo - Secretaria } \\
\text { Municipal de Planejamento }\end{array}$ & $\begin{array}{c}\text { Ana Lucia Ancona/ } \\
\text { Maria Teresa O Grillo }\end{array}$ & $\begin{array}{c}\text { Carlos Malzyner/ } \\
\text { Pedro Algodoal }\end{array}$ & $\begin{array}{c}\text { Denise G L Malheiros/ } \\
\text { Rita de Cássia Ogera }\end{array}$ & $\begin{array}{l}\text { Denise G L Malheiros/ } \\
\text { Rita de Cássia Ogera }\end{array}$ \\
\hline $\begin{array}{l}\text { Prefeitura de São Paulo - Secretaria } \\
\text { do Verde e Meio Ambiente }\end{array}$ & $\begin{array}{c}\text { José Carlos L R Almeida/ } \\
\text { Yan Roberto Maciel }\end{array}$ & $\begin{array}{c}\text { Luis Antonio D Quitério/ } \\
\text { Gina Rizpah Besen }\end{array}$ & $\begin{array}{c}\text { Izabel Maura F Lavendowski/ } \\
\text { Laura Lucia Ceneviva }\end{array}$ & $\begin{array}{l}\text { Laura Lucia Ceneviva/ } \\
\text { Renato Arnaldo Tagnin }\end{array}$ \\
\hline $\begin{array}{l}\text { Prefeitura de São Paulo - Secretaria } \\
\text { de Implementação das Sub- } \\
\text { Prefeituras (SIS) }\end{array}$ & --------- & $\begin{array}{l}\text { Tadeu Dias Paes/ } \\
\text { Antonio Pascoal Pontieri }\end{array}$ & $\begin{array}{c}\text { Tadeu Dias Paes/ } \\
\text { Loide Cruz V Parlato }\end{array}$ & --------- \\
\hline
\end{tabular}

FONTE: Elaborado pela autora. 


\section{Segmento: Sociedade CIVIL}

\begin{tabular}{|c|c|c|c|c|c|c|c|}
\hline \multicolumn{2}{|c|}{$1999-2000$} & \multicolumn{2}{|c|}{ 2001-2002 } & \multicolumn{2}{|c|}{ 2003-2004 } & \multicolumn{2}{|c|}{ 2005-2007 } \\
\hline TITULAR & SUPLENTE & TITULAR & SUPLENTE & TITULAR & SUPLENTE & TITULAR & SUPLENTE \\
\hline $\begin{array}{l}\text { ACISE - Assoc. } \\
\text { Comercial, } \\
\text { Industrial e de } \\
\text { Serviços de Embu } \\
\text { João Paulino R } \\
\text { Ribeiro }\end{array}$ & $\begin{array}{l}\text { ACIIS - Assoc. } \\
\text { Comercial e } \\
\text { Industrial de } \\
\text { Itapecerica da Serra }\end{array}$ & $\begin{array}{l}\text { ACISE - Assoc. } \\
\text { Comercial, } \\
\text { Industrial e de } \\
\text { Serviços de Embu } \\
\text { João Paulino R } \\
\text { Ribeiro }\end{array}$ & $\begin{array}{c}\text { AESUL - } \\
\text { Associação das } \\
\text { Empresas da Região } \\
\text { Sul } \\
\text { Valderci M. } \\
\text { Machado }\end{array}$ & $\begin{array}{c}\text { ACEAM - } \\
\text { Carlos Alberto P } \\
\text { Souza }\end{array}$ & $\begin{array}{c}\text { S.O.S. Represa } \\
\text { Guarapiranga } \\
\text { Silvia Taglianeti }\end{array}$ & $\begin{array}{l}\text { ACEIS-Assoc. } \\
\text { Coml. Empresarial } \\
\text { Itapecerica da Serra } \\
\text { José Antonio } \\
\text { Valério }\end{array}$ & $\begin{array}{c}\text { ASSEMEG - } \\
\text { Associação das } \\
\text { Empresas de Embu- } \\
\text { Guaçu } \\
\text { Valdete Marques } \\
\text { Pacheco }\end{array}$ \\
\hline $\begin{array}{c}\text { AESUL - } \\
\text { Associação das } \\
\text { Empresas da } \\
\text { Região Sul } \\
\text { Valderci M. } \\
\text { Machado }\end{array}$ & $\begin{array}{c}\text { ASSEMEG - } \\
\text { Associação das } \\
\text { Empresas de Embu- } \\
\text { Guaçu } \\
\text { Daniel Rodrigues } \\
\text { Lourenço }\end{array}$ & $\begin{array}{c}\text { ASSEMEG - } \\
\text { Associação das } \\
\text { Empresas de } \\
\text { Embu-Guaçu } \\
\text { Hamilton Freire } \\
\text { Luta }\end{array}$ & $\begin{array}{l}\text { ACIIS - Assoc. } \\
\text { Comercial e } \\
\text { Industrial de } \\
\text { Itapecerica da Serra } \\
\text { José Cremm }\end{array}$ & $\begin{array}{c}\text { AESABESP - } \\
\text { Associação dos } \\
\text { Engenheiros da } \\
\text { SABESP } \\
\text { Eliana Irie Kazue } \\
\text { Kitahara }\end{array}$ & $\begin{array}{c}\text { AEAIS - } \\
\text { Claudio Silvestre } \\
\text { Rodrigues }\end{array}$ & $\begin{array}{l}\text { Assoc. Moradores } \\
\text { Favela Jd. } \\
\text { Ibirapuera } \\
\text { Osvaldo Alves da } \\
\text { Silva }\end{array}$ & $\begin{array}{c}\text { Fórum } \\
\text { Desenvolvimento } \\
\text { econômico e Social } \\
\text { da Região Sul São } \\
\text { Paulo } \\
\text { Suely Sbrousky }\end{array}$ \\
\hline $\begin{array}{l}\text { Colégio Interlagos } \\
\text { Inez Garbuio } \\
\text { Peralta }\end{array}$ & $\begin{array}{c}\text { Sindicato dos } \\
\text { Engenheiros de São } \\
\text { Paulo } \\
\text { Cid Barbosa Lima } \\
\text { Junior }\end{array}$ & $\begin{array}{l}\text { Associação dos } \\
\text { Engenheiros e } \\
\text { Arquitetos de } \\
\text { Itapecerica da } \\
\text { Serra } \\
\text { Claudio Silvestre }\end{array}$ & $\begin{array}{c}\text { AESABESP - } \\
\text { Associação dos } \\
\text { Engenheiros da } \\
\text { SABESP } \\
\text { Eliana Irie Kazue } \\
\text { Kitahara }\end{array}$ & $\begin{array}{c}\text { APRIS - } \\
\text { Horst Grassmann } \\
\text { Pfeiffer }\end{array}$ & $\begin{array}{l}\text { ACISE - Assoc. } \\
\text { Comercial, } \\
\text { Industrial e de } \\
\text { Serviços de Embu } \\
\text { José Roberto } \\
\text { Terassi }\end{array}$ & $\begin{array}{l}\text { Associação dos } \\
\text { Engenheiros e } \\
\text { Arquitetos de } \\
\text { Itapecerica da Serra } \\
\text { Cláudio Silvestre } \\
\text { Rodrigues }\end{array}$ & $\begin{array}{c}\text { AESABESP - } \\
\text { Associação dos } \\
\text { Engenheiros da } \\
\text { SABESP } \\
\text { Cristiano Augusto } \\
\text { Feitosa }\end{array}$ \\
\hline $\begin{array}{l}\text { Consab's Cotia } \\
\text { Ana Maria } \\
\text { Fernandes } \\
\text { Albanese }\end{array}$ & $\begin{array}{c}\text { Consab's Taboão da } \\
\text { Serra } \\
\text { Silvio Claudino } \\
\text { Pereira }\end{array}$ & $\begin{array}{c}\text { Associação Povo } \\
\text { em Ação } \\
\text { Olimpio Silva } \\
\text { Matos }\end{array}$ & $\begin{array}{c}\text { Sociedade } \\
\text { Comunitária Pq. } \\
\text { Bologne } \\
\text { João Ferreira Santos }\end{array}$ & $\begin{array}{c}\text { Associação de } \\
\text { Mulheres do Conj. } \\
\text { Hab. Adv. Campo } \\
\text { Limpo } \\
\text { Sebastião Ferraz } \\
\text { Arsene }\end{array}$ & $\begin{array}{c}\text { Associação de } \\
\text { Moradores Pq. das } \\
\text { Cerejeiras } \\
\text { Pedro Lopes }\end{array}$ & $\begin{array}{l}\text { Associação Favela } \\
\text { Alcindo Ferreira } \\
\text { Alsemo José } \\
\text { Almeida }\end{array}$ & $\begin{array}{c}\text { Sociedade } \\
\text { Beneficente Centro } \\
\text { de Cultura Afro- } \\
\text { Brasileira } \\
\text { Marcelo Luiz } \\
\text { Juvenal }\end{array}$ \\
\hline $\begin{array}{c}\text { FAGESP - } \\
\text { Federação das } \\
\text { Favelas de São } \\
\text { Paulo } \\
\text { Anselmo Jose de } \\
\text { Almeida }\end{array}$ & $\begin{array}{c}\text { Associação de } \\
\text { Moradores Pq. Das } \\
\text { Cerejeiras } \\
\text { Pedro Lopes }\end{array}$ & $\begin{array}{c}\text { Consab's Taboão } \\
\text { da Serra } \\
\text { Silvio Claudino } \\
\text { Pereira }\end{array}$ & $\begin{array}{l}\text { SAB Juquitiba e } \\
\text { Adjacências } \\
\text { Joaquim Pereira } \\
\text { Soares }\end{array}$ & $\begin{array}{l}\text { Associação Favela } \\
\text { Alcindo Ferreira } \\
\text { Alsemo José } \\
\text { Almeida }\end{array}$ & $\begin{array}{c}\text { SAB Parque } \\
\text { Mirizola } \\
\text { Odair Sanseverino }\end{array}$ & $\begin{array}{c}\text { Associação Social e } \\
\text { Cultural Letras } \\
\text { Mágicas } \\
\text { Clarice Bispo } \\
\text { Pereira }\end{array}$ & $\begin{array}{c}\text { Marina } \\
\text { Guarapiranga } \\
\text { José Luiz V Bonini }\end{array}$ \\
\hline
\end{tabular}




\begin{tabular}{|c|c|c|c|c|c|c|c|}
\hline \multicolumn{2}{|c|}{ 1999-2000 } & \multicolumn{2}{|c|}{ 2001-2002 } & \multicolumn{2}{|c|}{ 2003-2004 } & \multicolumn{2}{|c|}{ 2005-2007 } \\
\hline TITULAR & SUPLENTE & TITUlar & SUPLENTE & TITULAR & SUPLENTE & TITUlar & SUPLENTE \\
\hline $\begin{array}{c}\text { GAIA - } \\
\text { Movimento } \\
\text { Ecológico e } \\
\text { Social } \\
\text { Carlos Alberto } \\
\text { Pinheiro de Souza }\end{array}$ & $\begin{array}{l}\text { Sociedade Ecológica } \\
\text { Amigos de Embu } \\
\text { Prof. Dr. Antonio } \\
\text { Luiz Cagnin }\end{array}$ & $\begin{array}{c}\text { Faculdade } \\
\text { Interlagos de } \\
\text { Educação e } \\
\text { Cultura } \\
\text { João Jorge Peralta }\end{array}$ & $\begin{array}{c}\text { UNISA - } \\
\text { Universidade de } \\
\text { Santo Amaro } \\
\text { Emerson Alexandre } \\
\text { Zago }\end{array}$ & $\begin{array}{l}\text { Associação Favela } \\
\text { Fim de Semana } \\
\text { Osvaldo Alves da } \\
\text { Silva }\end{array}$ & $\begin{array}{c}\text { SAB Vila Remo } \\
\text { Arnaldo Francisco } \\
\text { Silva }\end{array}$ & $\begin{array}{c}\text { AVEPEMA - } \\
\text { Associação Verde } \\
\text { Proteção Meio } \\
\text { Ambiente } \\
\text { Antonio Abel Rocha } \\
\text { da Silva }\end{array}$ & $\begin{array}{l}\text { ACEB - Assoc } \\
\text { Beneficiente } \\
\text { Consciencia } \\
\text { Ecológica Brasil } \\
\text { Maria Amélia } \\
\text { Lofrano }\end{array}$ \\
\hline $\begin{array}{c}\text { S.O.S. Represa } \\
\text { Guarapiranga } \\
\text { Marussia Whately }\end{array}$ & $\begin{array}{l}\text { Espaço, Formaç̧ão, } \\
\text { Assessoria e } \\
\text { Documentação } \\
\text { Mauro Scarpinatti }\end{array}$ & $\begin{array}{c}\text { GAIA - } \\
\text { Movimento } \\
\text { Ecológico e Social } \\
\text { Carlos Alberto } \\
\text { Pinheiro de Souza }\end{array}$ & $\begin{array}{l}\text { Sociedade Ecológica } \\
\text { Amigos de Embu } \\
\text { Prof }{ }^{\circ} \text { Dr. Antonio } \\
\text { Luiz Cagnin }\end{array}$ & $\begin{array}{c}\text { Associação Social } \\
\text { Letras Mágicas } \\
\text { Clarice Bispo } \\
\text { Pereira }\end{array}$ & & $\begin{array}{c}\text { CIESP - Regional } \\
\text { Cotia } \\
\text { André Pires de } \\
\text { Oliveira Jr. }\end{array}$ & $\begin{array}{c}\text { ACISE - Assoc. } \\
\text { Comercial, } \\
\text { Industrial e de } \\
\text { Serviços de Embu } \\
\text { José Roberto Terassi }\end{array}$ \\
\hline $\begin{array}{l}\text { Sailing Club } \\
\text { Romeu Bonini }\end{array}$ & $\begin{array}{c}\text { Marina } \\
\text { Guarapiranga } \\
\text { José Luiz V Bonini }\end{array}$ & $\begin{array}{c}\text { Marina } \\
\text { Guarapiranga } \\
\text { José Luiz V } \\
\text { Bonini }\end{array}$ & ------ & $\begin{array}{c}\text { CIESP - } \\
\text { José Paulino R } \\
\text { Ribeiro }\end{array}$ & $\begin{array}{c}\text { ASSEMEG - } \\
\text { Assoc. Empresas } \\
\text { de Embu-Guaçu } \\
\text { Hamilton F. Luta }\end{array}$ & $\begin{array}{l}\text { Colégio e Faculdade } \\
\text { Interlagos } \\
\text { Inês Garbuio Peralta }\end{array}$ & $\begin{array}{l}\text { Associação Paulista } \\
\text { Cons. Em Meio } \\
\text { Ambiente } \\
\text { José Jorge Peralta }\end{array}$ \\
\hline $\begin{array}{c}\text { Sociedade } \\
\text { Amigos Recanto } \\
\text { Campo Belo } \\
\text { Paulo Roberto de } \\
\text { Assis }\end{array}$ & $\begin{array}{l}\text { Soc. Amigos Jd. } \\
\text { Progresso e } \\
\text { Adjacências } \\
\text { João Fernandes de } \\
\text { Sena }\end{array}$ & $\begin{array}{c}\text { SAB Vila Remo } \\
\text { Arnaldo Francisco } \\
\text { Silva }\end{array}$ & $\begin{array}{c}\text { Associação de } \\
\text { Moradores Pq. Das } \\
\text { Cerejeiras } \\
\text { Pedro Lopes }\end{array}$ & $\begin{array}{l}\text { Faculdade } \\
\text { Interlagos } \\
\text { Iara Sakitani }\end{array}$ & $\begin{array}{c}\text { Faculdade } \\
\text { Europan } \\
\text { José Jorge Peralta }\end{array}$ & $\begin{array}{c}\text { INEAA - Instituto } \\
\text { Nacional Estudos } \\
\text { Ambientais } \\
\text { Avançados } \\
\text { Nelson Terra Barth }\end{array}$ & $\begin{array}{l}\text { IN-PACTO Instituto } \\
\text { Proteção Ambiental } \\
\text { Cotia/Tietê Oeste } \\
\text { Maria Auxiliardora } \\
\text { de Assis Ferreira }\end{array}$ \\
\hline $\begin{array}{c}\text { União de } \\
\text { Mulheres do } \\
\text { Município de São } \\
\text { Paulo } \\
\text { Maria Sampaio B } \\
\text { Ostrowski }\end{array}$ & $\begin{array}{c}\text { OAB }-102^{\mathrm{a}} \\
\text { Subseção de Santo } \\
\text { Amaro } \\
\text { Elza de Souza C } \\
\text { Ferreira }\end{array}$ & $\begin{array}{l}\text { SOS Manancial } \\
\text { Rio Cotia } \\
\text { Cristina } \\
\text { Marcondes Fowier }\end{array}$ & $\begin{array}{l}\text { S.O.S. Represa } \\
\text { Guarapiranga } \\
\text { Ivan Metran } \\
\text { Whately }\end{array}$ & $\begin{array}{c}\text { Marina } \\
\text { Guarapiranga } \\
\text { José Luiz V } \\
\text { Bonini }\end{array}$ & & $\begin{array}{l}\text { ONG Mãos Amigas } \\
\text { Antonio Guedes } \\
\text { Silva Filho }\end{array}$ & $\begin{array}{l}\text { Soc. Amigos capela } \\
\text { do Socorro } \\
\text { Dejair Lopes da } \\
\text { Silva }\end{array}$ \\
\hline $\begin{array}{c}\text { UNISA - } \\
\text { Universidade de } \\
\text { Santo Amaro } \\
\text { Emerson } \\
\text { Alexandre Zago }\end{array}$ & $\begin{array}{c}\text { USP - Escola } \\
\text { Politécnica da } \\
\text { Universidade de São } \\
\text { Paulo } \\
\text { Monica F A Porto }\end{array}$ & $\begin{array}{c}\text { União de } \\
\text { Mulheres do } \\
\text { Município de São } \\
\text { Paulo } \\
\text { Terezinha Oliveira } \\
\text { Gonzaga }\end{array}$ & $\begin{array}{c}\text { Igreja Messiânica } \\
\text { Mundial do Brasil } \\
\text { Janine Solange } \\
\text { Santos }\end{array}$ & $\begin{array}{c}\text { Sociedade } \\
\text { Ecológica Amigos } \\
\text { de Embu } \\
\text { Samuel Brasil R P } \\
\text { Carvalho }\end{array}$ & $\begin{array}{l}\text { SOS Rio Cotia } \\
\text { Yara Rezende de } \\
\text { Toledo }\end{array}$ & $\begin{array}{c}\text { S.O.S. Represa } \\
\text { Guarapiranga } \\
\text { Celia Cymbalista }\end{array}$ & $\begin{array}{c}\text { GAIA - Movimento } \\
\text { Ecológico e Social } \\
\text { Carlos Alberto P } \\
\text { Souza }\end{array}$ \\
\hline
\end{tabular}

FONTE: Elaborado pela autora. 